JOSÉ HILÁRIO FARINA PORTES

\title{
A REGULAÇÃO DA INDÚSTRIA DE ENERGIA ELÉTRICA NO BRASIL E SEU IMPACTO NAS RELAÇÕES COM OS CLIENTES: \\ UMA PERSPECTIVA EMPRESARIAL
}

\begin{abstract}
Dissertação apresentada ao Programa Interunidades de Pós-Graduação em Energia da USP (Escola Politécnica/ Instituto de Eletrotécnica e Energia/ Instituto de Física/ Faculdade de Economia e Administração) para obtenção do título de Mestre em Energia.
\end{abstract}

SÃO PAULO

Outubro - 1998 
Aos meus pequenos Gabriel e Víctor e à querida companheira Rita, pelo tempo que deles emprestei para concluir este trabalho. 
"O que caracteriza o crescimento é o impulso, a garra, - entusiasmo da conquista, os resultados estimuladores, a superação de metas, a luta incessante" (autor anônimo, anotado de longa data).

"Nós reconhecemos que não há um único diagrama para reinventar as indústrias elétricas. ... o futuro será no fim determinado pelas idéias, esperanças e visão das pessoas" (SMELOFF, Ed, et al. in Reinventing Electric Utilities). 


\section{AGRADECIMENTOS}

Ao Prof. Dr. Celio Bermann, pela atenção, estímulo e dedicação a mim concedidos e pela permanente orientação e tolerância aos nossos passos, nem sempre contínuos.

Ao Prof. Dr. Murilo Fagá, Coordenador do Programa Interunidades de Pós Graduação em Energia, pelo apoio e atenção constantes.

A todos aqueles que me ajudaram na busca de material bibliográfico, idéias e revisão desse trabalho: Celso, João André, Pedro, Flávia, Nazaré e tantos outros.

Ao Prof. Dr. Tahan e ao Prof. Dr. Boa Nova pela dedicação ao exame de nossa dissertação.

À CESP/ELEKTRO, pela oportunidade de ter podido crescer como pessoa e como
profissional.

À Universidade de São Paulo, pela honra de ter pertencido a seu corpo discente. 


\section{SUMÁRIO}

LISTA DE TABELAS

LISTA DE FIGURAS

LISTA DE ANEXOS

LISTA DE ABREVIATURAS

RESUMO

ABSTRACT

1. INTRODUÇÃO

1.1. OBJETIVO

1.2. JUSTIFICATIVA

1.3. METODOLOGIA

2. DEMOCRACIA, PARTICIPAÇÃO POLÍTICA, SERVIÇO PÚBLICO, SERVIÇO DE UTILIDADE PÚBLICA, MONOPÓLIO NATURAL E REGULAÇÃO: CONCEITOS

3. A INDÚSTRIA DE ENERGIA ELÉTRICA NO BRASIL

3.1. EVOLUÇÃO HISTÓRICA

3.1.1. Os Primórdios da Indústria de Energia Elétrica no Brasil - até 1930

3.1.2. A era Vargas e o Código de Águas

3.1.3. A Formação da Indústria de Energia Elétrica Nacionalizada

3.1.4. O período pós-1973

3.2. CARACTERÍSTICAS GERAIS DA INDÚSTRIA DE ENERGIA ELÉTRICA NO BRASIL

4. ALGUMAS EXPERIÊNCIAS INTERNACIONAIS DE REGULAÇÃO DOS SERVIÇOS DE ENERGIOA ELÉTRICA

4.1. A EXPERIÊNCIA DA INGLATERRA

4.2. A EXPERIÊNCIA NA NORUEGA

4.3. A EXPERIÊNCIA DA AMÉRICA LATINA

4.4. A EXPERIENNCIA DOS ESTADOS UNIDOS

5. A VISÃO EMPRESARIAL DA PARTICIPAÇÃO DO PÚBLICO NA INDÚSTRIA ELÉTRICA AMERICANA: ESTUDO DE CASO 
5.1.1. Antecedentes Históricos

5.1.2. O Atendimento ao Consumidor como Estratégia Empresarial

5.1.3. Os Resultados da PG\&E

5.2. ESTUDO DE CASO 2: PROPOSTA DE PLANO DE PARTICIPAÇÃO PÚBLICA DO EDISON ELECTRIC INSTITUTE

5.2.1. A Necessidade da Participação Pública

5.2.2. As Metas da Participação Pública

5.2.3. Tipos de Participação Pública

5.2.4. Outras Práticas Propostas

\section{EVOLUÇÃO RECENTE DA REGULAÇÃO DA INDÚSTRIA} DE ENERGIA ELÉTRICA NO BRASIL

6.1. O RELATÓRIO COOPERS \& LYBRAND

6.1.1. O Mercado Atacadista de Energia

6.1.2. Distribuição e Varejo

6.1.3. Encargos da Distribuição

6.2. A AGÊNCIA NACIONAL DE ENERGIA ELÉTRICA - ANEEL

6.3. A COMISSÃO DE SERVIÇOS PÚBLICOS DE ENERGIA - CSPE: AS PERSPECTIVAS REGULATÓRIAS NO ESTADO DE SÃO PAULO

6.4. A REGULAÇÃO E A DEFESA DA CONCORRÊNCIA

6.5. A INDÚSTRIA DE ENERGIA ELÉTRICA NO BRASIL E OS DIREITOS DO CONSUMIDOR

6.5.1. Antecedentes Históricos

6.5.2. O Código de Defesa do Consumidor

6.5.3. Controle dos Niveis de Qualidade do Produto e Serviços

6.5.4. O conselho de Clientes

7. CONCLUSÕES 


\section{LISTA DE TABELAS}

TABELA 3.1 - Grandezas de energia elétrica e de economia do Brasil...........36

TABELA 4.1 - Número de empresas de serviço público de eletricidade e sua capacidade nominal de geração - EUA - 1991..........................50 


\section{LISTA DE FIGURAS}

FIGURA 2.1 - Agentes Ativos na indústria elétrica

FIGURA 2.2 - Poder Organizacional e Sociedade.

FIGURA 3.1 - Distribuição do consumo final de energia elétrica no Brasil 1997 


\section{LISTA DE ANEXOS}

ANEXO I - Quadro das privatizações no Brasil - Agosto de 1998 118

ANEXO II - Indicadores e parâmetros de qualidade do fornecimento de energia elétrica

ANEXO III - Minuta do Projeto de Lei do Deputado Rui Falcão 132

ANEXO IV - Código de Defesa do Consumidor

ANEXO V - Regimento interno do Conselho de Clientes da ELEKTRO 


\section{LISTA DE ABREVIATURAS}

ABCE

AGERGS

AMFORP

ANATEL

ANEEL

ANP

ABRADEE

BELSA

BIRD

BNDES

CAC'S

CADE

CNAMBRA

CAEEB

ccc

CDC

CEC

CEEE

CEEE (RS)

CEGB

CELP

- Associação Brasileira de Concessionárias de Energia

- Agência Estadual de Regulação dos Serviços Públicos Delegados do Rio Grande do Sul

- "American \& Foreign Power Company"

- Agência Nacional de Telecomunicações

- Agência Nacional de Energia Elétrica

- Agência Nacional do Petróleo

- Associação Brasileira das Distribuidoras de Energia Elétrica

- Bandeirantes de Eletricidade S/A

- Banco Mundial

- Banco Nacional de Desenvolvimento Econômico e Social

- Centrais de Atendimento ao Cliente

- Conselho Administrativo de Defesa Econômica

- Comitê de Estudo Canadense-Americano-Brasileiro

- Companhia Auxiliar de Empresas Elétricas Brasileiras

- Conta de consomo de Combustiveis

- Código de Defesa do Consumidor

- "California Energy Comission"

- Comissão Estadual de Energia Elétrica

- Companhia Estadual de Energia Elétrica

- "Central Electricity General Board"

- Centrais Elétricas Paulistas 


\begin{tabular}{ll} 
CELUSA & - Centrais Elétricas Urubupungá \\
CEMAT & - Centrais Elétricas do Mato Grosso \\
CEMIG & - Companhia Energética de Minas Gerais \\
CERJ & - Companhia de Eletricidade do Rio de Janeiro \\
CESP & - Companhia Energética de São Paulo \\
CHERP & - Centrais Hidroelétricas do Rio Paranapanema \\
CHERP & - Companhia Hidroelétrica do Rio Pardo \\
CHESF & - Companhia Hidroelétricas do São Francisco \\
CIBP & - Comissão Interestadual da Bacia do Paraná \\
CIBPU & - Comissão Interestadual da Bacia do Paraná Uruguaí \\
CNAEE & - Conselho Nacional de Energia Elétrica \\
COD’S & - Centros de Operação da Distribuição \\
CODI & - Comitê de Distribuição \\
COELBA & - Companhia de Eletricidade do Estado da Bahia \\
COMERPA & - Companhia de Melhoramentos do Paraibuna \\
CONSESPE & - Conselho Estadual de Serviços Públicos de Energia \\
COPEL & - Companhia Paranaense de Energia \\
CPFL & - Companhia Paulista de Força e Luz \\
CPUC & - “California Public Utilities Commission” \\
CRA'S & - Centrais Regionalizadas de Atendimento \\
CRC & - Cotas de Resultados a Compensar \\
CSPE & - Comissão de Serviços Públicos de Energia \\
CUB & - Citizem Utility Board” \\
DAEE & Departamento de Águas e Energia Elétrica \\
\hline
\end{tabular}




\begin{tabular}{|c|c|}
\hline DNAE & - Departamento Nacional de Águas e Energia \\
\hline DNAEE & - Departamento Nacional de Águas e Energia Elétrica \\
\hline DNPM & - Departamento Nacional de Produção Mineral \\
\hline DNPM & - Divisão de Águas do Departamento Nacional Mineral \\
\hline DOE & - Ministério de Energia dos EUA \\
\hline DPDC & - Departamento de Proteção e Defesa do Consumidor \\
\hline EBASCO & - "Electric Bond.And.Share.Company" \\
\hline ELETROBRÁs & - Centrais Elétricas Brasileiras \\
\hline ELETROPAULO & - Eletricidade de São Paulo S/A \\
\hline ENERGIPE & -Empresa Energética de Sergipe \\
\hline ESCELSA & - Espírito Santo Centrais Elétricas \\
\hline FEF & - Fundo Federal de Eletrificação \\
\hline FERC & - "Federal Energy Regulatory Commission" \\
\hline FPA & - "Federal Public Act" \\
\hline FPC & - "Federal Public Commission" \\
\hline GE & - General Electric Company \\
\hline GENCOS & - Companhias de Geração \\
\hline IEP'S & -"Independent Energy Producers" \\
\hline IUEE & - Imposto Único sobre Energia Elétrica \\
\hline MAE & - Mercado Atacadista de Energia \\
\hline MME & - Ministério das Minas e Energia \\
\hline NARUC & -"National Association of Regulators of Ulities Companies" \\
\hline NEPA & - "National Enviroment Policiy Act" \\
\hline NGC & -“ Nacional Grid.Company" \\
\hline
\end{tabular}




$\begin{array}{ll}\text { OFFER } & \text {-"Office of Electricity Regulation" } \\ \text { OIS } & \text { - Operador Independente do Sistema } \\ \text { PAEG } & \text { - Programa de Ação Econômica do Governo } \\ \text { PG\&E } & \text { - Pacific Gas and Electric Company } \\ \text { PND } & \text { - Programa Nacional de Desestatização } \\ \text { POU'S } & \text {-"Public Owners Utilities" } \\ \text { PUC } & \text {-"Public Utility Commission" } \\ \text { PUHCA } & \text {-"Public Utility Holding Company Act" } \\ \text { PURPA } & \text {-"Public Utilities Regulatory Policy Act” } \\ \text { QF'S } & \text {-"Qualifying Facilities" } \\ \text { REA } & \text {-"Rural Electricity Administration” } \\ \text { REC } & \text {-“Regional Electricity Company" } \\ \text { RGR } & \text { - Reserva Global de Reversão } \\ \text { SDE } & \text { - Secretaria de Direito Econômico } \\ \text { SEAE } & \text { - Secretaria de Acompanhamento Econômico } \\ \text { SINTREL } & \text { - Sistema Nacional de Transmissão de Energia Elétrica } \\ \text { SNDC } & \text { - Sistema Nacional de Defesa do Consumidor } \\ \text { TASC } & \text { - Teleatendimento por Sistema Centralizado } \\ \text { TRANSCOS } & \text {-Companhias de Transmissão } \\ \text { USELPA } & \text { - Usinas Elétricas do Paranapanema } \\ & \end{array}$




\section{RESUMO}

Este trabalho examina as questões regulatórias da indústria de energia elétrica no Brasil sob a perspectiva das relações com os clientes. Para tanto, busca relacioná-las aos conceitos de democracia, participação política, serviço publico, serviço de utilidade pública e monopólio natural, destacando as condicionantes da participação do público consumidor nas decisões da indústria de energia elétrica.

O escopo central corresponde as atividades de distribuição de energia elétrica, destacando-as no contexto do cenário institucional brasileiro, indicando a dimensão prospectiva das mudanças em curso.

Considera, ainda, a evolução das relações com os clientes na indústria de energia elétrica brasileira, bem como evidencia os desafios a serem transpostos.

Quanto às tendências mundiais das transformações da indústria elétrica, identifica pontos importantes da regulação da Inglaterra, América Latina, Noruega e particularmente dos EUA, fornecendo elementos para as possibilidades de implantação no caso brasileiro.

O trabalho recorre, ainda, aos estudos de caso da Pacific Gas \& Electric e do Edison Electric Institute para sugerir a formulação de um programa empresarial de participação do público.

A existência de regulação em âmbito federal e estadual, permite concluir, que a descentralização e articulação de suas atuações, produzirão efeitos positivos na mediação dos conflitos de interesses. 
Finalizando, o trabalho aponta para um posicionamento empresarial que supere o caráter impositivo dos mecanismos regulatórios e indica a necessidade da criação e ampliação de canais de comunicação entre empresa e clientes. 


\section{ABSTRACT}

This investigation provides a national analysis of electricity industry in Brazil and it is focused on the perspective of clients relationship.

The assessment is related under some concepts: Democracy, Political Participation, Public Service, Public Utility, Natural Monopoly and Regulation.

On the other hand is showed clients participation in the main decisions of the industry.

The main subject corresponds the activities of distribution of electricity , highlighting them in the context of Brazilian institutional scenery, indicating the prospect of the changes in course.

It considers still the evolution of the relationships with the clients in the industry of Brazilian eletricity as well as it evidences the challenges to be transponds.

In the way of world tendencies of tranformation the electricity industries, it identifies important points of the regulation in England, Latin America, Norway and particulary of the USA, supplying elements to subsidize its implement in the Brazil case.

The work appeals still to the studies of case of Pacific Gas \& Electric Company and of Edison Electric Institute to suggest the formulation of a managerial program of the public participation. 
The existence of the regulation in Federal and State allow to end that the decentralization and articulation of its performances, they will produce positive effects in the mediation of theconflicts of interests.

Finally the investigation aims for a managerial positioning that overcomes the caracter impose of the regulatory mechanisms and indicates necessity to create and to extend communication channels between company and clients. 


\section{INTRODUÇÃO}

\subsection{OBJETIVO}

O presente trabalho objetiva abordar a questão do serviço público de energia elétrica segundo conceitos relacionados com a participação do público consumidor nas decisões que o afetam, num movimento coletivo de defesa de seus interesses.

O escopo central corresponde às atividades de distribuição de energia elétrica, compreendendo os serviços de operação dos sistemas elétricos de média e baixa tensões e $o$ atendimento comercial.

O trabalho considera ainda, a distribuição de energia elétrica dentro do cenário institucional brasileiro, indicando a dimensão prospectiva das mudanças em curso. O debate que acompanha essas mudanças contempla os aspectos relacionados ao controle e a regulação pelo Estado das atividades da indústria elétrica que serão desempenhadas pela iniciativa privada. Isso demonstra a acentuada movimentação da dicotomia público/privado, ensejando discussões efetivas a respeito do seu novo desenho e forma de funcionamento.

Os principais eixos associados às transformaçōes preconizadas já evidenciam ampla participação do capital privado, a partir da total privatização das empresas, como também o surgimento de Agências Reguladoras, que tanto no âmbito Federal como no Estadual, buscarão exercer a fiscalização e o controle no novo modelo.

Avalia - se as iniciativas do Governo Federal, de criar a Agência Nacional de Energia Elétrica-ANEEL, do Governo do Estado de São Paulo, de constituir a Comissão de Serviços Públicos de Energia-CSPE, visando garantir as presenças 
do Poder Público e dos clientes no processo de regulação e fiscalização das empresas de energia elétrica.

No intuito de fazer uma abordagem prática, o trabalho referencia a experiência da empresa americana Pacific Gas \& Electric Company e do Edison Electric Institute, reunindo elementos que permitem a formulação de um programa de participação dos usuários dos serviços, indispensável às empresas de distribuição de energia elétrica. Tal programa identifica ações de ordem prática, através da criação de canais de comunicação que garantirão de forma duradoura e equilibrada a participação do público consumidor nas decisões que o afetam.

É abordada a perspectiva da regulação como sendo um mecanismo de imposição das relações empresa/cliente e observada a necessidade da visão empresarial inserir as questões, a ela associadas, nos seus procedimentos administrativos.

\subsection{JUSTIFICATIVA}

As últimas três décadas foram marcadas pela forte presença do Estado na provisão da infra-estrutura de serviços públicos no Brasil. $O$ regime autoritário predominou em metade desse período, e somente nos últimos dez anos é que a democratização evoluiu, de fato, com o cidadão participando do processo de decisão política através do voto, passando a experimentar niveis crescentes de liberdade de expressão individual e coletiva.

Durante o regime autoritário, observou-se o fortalecimento de grupos econômicos e o surgimento de estatais fortes, fruto da presença necessária, em certo limite, do Estado, particularmente nos serviços públicos em regime de monopólio. 
Com a introdução do voto do cidadão, o fortalecimento das relações dos grupos de interesse e de pressão com o poder foi de fundamental importância para a consolidação democrática no país, permitindo que grandes organizações, associações, sindicatos, partidos, das mais diversas naturezas e ideologias, se inserissem no contexto da atividade político-econômica do país.

É imprescindivel, que a atividade econômica seja focalizada como um instrumento de desenvolvimento social, e dessa forma, o acesso aos insumos básicos, como a energia elétrica, é considerada de fundamental importância.

Assim sendo, a questão da energia elétrica vem se colocar como fator decisivo no processo de emancipação do cidadão, e da sociedade.

Pode-se, mesmo, indagar se a continuidade de tal processo não poderia ser considerado como o indivíduo, evoluindo de uma fase de conquista da cidadania , para a de reconhecimento de seus direitos numa sociedade de consumo - como agentes consumidores.

A organização institucional e o processo decisório da instituição denominada setor elétrico se inserem na abordagem, sendo que cultivou, e ainda cultiva em suas estruturas grande parte das anomalias, próprias de um monopólio de serviço público essencial, e que esboça movimentos de ruptura com o seu passado. Neste particular, torna-se extremamente oportuna a formatação de uma nova ordem institucional, a partir de uma redefinição do seu papel. Nesta perspectiva, a participação dos agentes consumidores assume fundamental importância no processo.

A indústria de energia elétrica brasileira está entrando em uma nova era, que muito bem pode ser identificada como o retorno a iniciativa privada de algumas empresas estatais e privatização de outras, reconhecendo-se, entretanto, um novo cenário em que as empresas de serviço público estão se tornando cada vez mais 
diversificadas em função do avanço tecnológico, características de seus sistemas, mercados atendidos, concorrência e organização de consumidores.

A estrutura do mercado de energia elétrica está mudando e acreditamos que tão significativa quanto a evolução das mudanças estruturais fundamentais no setor elétrico é a mudança na relação básica entre a empresa de serviço público e o consumidor, bem como sua participação no processo decisório.

As transformações das relações entre as empresas de distribuição de energia elétrica e seus consumidores, estão caminhando, inclusive, para um ambiente competitivo onde a tarifa será fixada pelo mercado no que se refere aos grandes consumidores. $\mathrm{O}$ administrador da empresa distribuidora deve, portanto, considerar e entender como o consumidor em conjunto com o mercado determinam este tarifa, quais são os componentes dela e que instrumentos/técnicas são necessários para incorporar as expectativas do lado da demanda no processo de decisão empresarial.

Torna-se necessária uma reflexão sobre como se dará a representatividade dos consumidores individuais, no processo regulatório institucional do setor elétrico. Esses consumidores, cativos nas áreas de concessão das empresas, também podendo ser chamados de consumidores difusos, devem ser considerados no novo modelo institucional, em curso. Ressalte-se a necessidade diante do fato de que a partir do momento em que as empresas do setor elétrico passarem a ser administradas pelo capital privado, um novo monopólio poderá gradualmente se formar e caberá à sociedade como um todo, o papel fundamental, de fiscalizar, opinar, e exigir das empresas prestadoras dos serviços, a qualidade, confiabilidade, a modicidade das tarifas de energia elétrica e a diminuição dos custos na prestação dos serviços, garantindo que os aumentos de produtividade e eficiência empresarias sejam repartidos entre os agentes do mercado e as empresas. 
Os instrumentos para o cidadão fazer valer o seu direito de consumidor, começaram a evoluir no Brasil a partir do surgimento do Código de Defesa do Consumidor - CDC, em 1992. Muito embora, as recentes ocorrências relacionadas com o desabastecimento de energia elétrica verificadas nas áreas de concessão da LIGHT e da CERJ, no Estado do Rio de Janeiro, mostraram que a primeira instância de defesa dos interesses dos consumidores foi o PROCON dentro do contexto do CDC, julgamos, entretanto, que sua atuação tende a ser limitada, se considerarmos a abrangência e complexidade da indústria de energia elétrica.

Esta complexidade está representada pelos diversos fatores que impactam os níveis de qualidade na distribuição de energia elétrica, bem como pela diversificada gama de serviços associados, os quais estão ligados a cada consumidor.

Diante disso, novas instâncias e posturas deverão ser implementadas visando a aproximação do público consumidor, dos serviços públicos de eletricidade, garantindo os seus interesses. Além disso, vale ressaltar que somente numa sociedade democrática é que poderão surgir os elementos necessários para tal intento.

Em função da dinâmica das transformações da indústria de energia elétrica no Brasil, fixamos como referência para os dados e informações deste trabalho, o mês de Agôsto de 1998.

\subsection{METODOLOGIA}

O trabalho foi estruturado a partir de uma pesquisa bibliográfica dividida nas seguintes questões: a conceitual e política do tema proposto, a legislação da indústria de energia elétrica , a retrospectiva histórica dessa indústria no Brasil, e as experiências internacionais nos processos de regulação, focalizando dois 
estudos de caso americanos, o da empresa Pacific Gas \& Electric Company e o do Édison Electric Institute.

Em nossa pesquisa bibliográfica, buscamos responder de que forma e em que medida os autores ou entidades pesquisados abordavam a questão da participação pública no contexto das decisões relacionadas com a indústria de eletricidade, bem como quais os mecanismos colocados à disposição do público para comunicação e sua influência individual e coletiva, no processo decisório nos âmbitos empresarial e institucional.

$\mathrm{Na}$ questão conceitual e política, buscamos aprofundar 0 tema relacionando-o com o conceito de democracia direta e indireta, destacando, em certa perspectiva histórica, a abertura política no Brasil, projetando um caminho necessário para que a transição do cidadão, da condição de simples usuário dos serviços públicos de energia elétrica para a de consumidor revestido de seus direitos, venha se dar de forma concorrente com as transformações em curso. 0 advento do Código de Defesa do Consumidor é comentado como um instrumento essencial nessa direção. Uma abordagem conceitual a respeito do serviço público se fez necessária. Dessa abordagem resultou uma definição de serviço público, evoluindo na direção da teoria do monopólio natural, focalizando-se suas críticas e defesas. No sentido de introduzir o tema da regulamentação dos serviços públicos, fomos buscar na literatura suas raízes teóricas, destacando-se os pontos que demonstram sua pertinência no âmbito da indústria de energia elétrica.

A pesquisa da legislação da indústria de energia elétrica no Brasil permitiu recompor uma breve evolução histórica e identificar pontos de destaque no arcabouço institucional brasileiro. Exemplos desses pontos são as alternâncias do domínio da indústria da energia elétrica no Brasil marcados, ora por capital nacional, ora por capital, estrangeiro. 
Embora, a participação do público consumidor tenha sido incipiente no passado, identificamos a evolução da legislação relacionada aos direitos dos consumidores. Os princípios da regulamentação do serviço público de energia elétrica, já presentes no Código de Águas, são aqui demonstrados. Quanto a legislação vigente, buscou-se salientar aspectos que explicitam o desejo de proporcionar abertura institucional para a participação do público, como também promover o controle e fiscalização das empresas de energia elétrica , a partir de garantia de níveis de qualidade do produto e dos serviços prestados. Nesse particular, são de fundamental importância as reflexões a respeito das atribuições da Agência Nacional de Energia Elétrica - ANEEL, do Governo Federal, e da Comissão de Serviços Públicos de Energia - CSPE, do Governo do Estado de São Paulo, bem como as articulações previstas entre ambas. Um particular aspecto mereceu destaque: o nível de autonomia dessas instâncias de fiscalização e controle e a efetiva representação do público consumidor em suas estruturas funcionais. A título de complementação do processo legislativo, o trabalho cita a proposta do Conselho Estadual de Energia Elétrica, formulada pelo Deputado Rui Falcão (PT-SP), não aprovada pela Assembléia Legislativa do Estado de São Paulo.

As experiências internacionais foram objetos de investigação sob três aspectos. O primeiro diz respeito a cinco experiências, que de alguma forma poderiam fornecer subsídios para o caso brasileiro: a americana, por se tratar de um país com características institucionais e territoriais similares a brasileira; a inglesa, pelo seu caráter radical e inovador; a norueguesa, dadas as características semelhantes as brasileiras quanto a predominância do seu parque hidroelétrico; as duas latino-americanas , a argentina e a chilena pela similaridade do contexto econômico e social com nosso país. Buscou-se, sempre que possível identificar pontos de evolução relacionados a participação do público consumidor bem como evidenciar os instrumentos de regulação dos níveis de qualidade do produto e dos serviços prestados. 
O segundo aspecto refere-se ainda a indústria americana destacando a empresa Pacific Gas \& Electric e sua experiência nas relações com os consumidores, abordando exemplos de conflitos locais vivenciados. O terceiro aspecto está associado a descrição de um Plano de Ação de Participação Pública produzido pelo Edison Electric Institute, dos EUA. A partir de uma adaptação as peculiaridades brasileiras propõe-se sua adoção como recomendação nesse trabalho. 


\section{DEMOCRACIA, PARTICIPAÇÃO POLÍTICA, SERVIÇO PÚBLICO, SERVIÇO DE UTILIDADE PÚBLICA, MONOPÓLIO NATURAL E REGULAÇÃO: CONCEITOS}

Para BOBBIO (1992, p.12) a democracia pode ser definida como "... um conjunto de regras de procedimento para formação de decisões coletivas, em que está prevista e facilitada a participação mais ampla possivel dos interessados. Acrescente-se que, se se inclui no conceito geral de democracia a estratégia do compromisso entre as partes através do livre debate para a formação de uma maioria, a definição aqui sugerida reflete melhor a realidade da democracia direta: - referendum, não podendo colocar os problemas a não ser sob a forma de excludência, de escolha forçada entre duas alternativas, obstaculiza o compromisso e fortalece o choque, e exatamente por isto é mais adequado para dirimir controvérsias sobre princípios do que para resolver conflitos de interesses".

A questão central, portanto, da participação do público no processo decisório do setor elétrico assume duas dimensões. A primeira está relacionada com a representação desse público junto a instituições governamentais visando a definição dos princípios e regras mais gerais que conduzirão a montagem, regulação e fiscalização do arcabouço legal dos serviços públicos de energia elétrica. A segunda está relacionada com os conflitos de interesses que vão estar acontecendo no cotidiano das relações empresa - consumidor.

Quanto a primeira dimensão colocada, ela está alicerçada no voto do cidadão investindo poderes aos seus representantes. Cumpre, no entanto, chamar atenção, segundo BOBBIO (1992, p. 11) , para uma "promessa não cumprida da democracia", traduzida pela ausência da educação para a cidadania, segundo a qual o cidadão investido do poder de eleger os próprios governantes acabaria por eleger os mais sábios, os mais honestos e os mais esclarecidos dentre os seus concidadãos. 
A segunda dimensão considerada, está relacionada as trocas comerciais entre as empresas prestadoras dos serviços e os consumidores, representadas pelos conflitos de interesses que se multiplicam na medida da inexistência de canais de comunicação e instrumentos que permitam a participação do público no processo de decisão empresarial.

Nesse particular, vemos como obstáculo a ser transposto, o despreparo de muitas empresas de serviço público de energia elétrica em oferecer confiabilidade de seus produtos junto aos consumidores, que muito bem pode ser demonstrado pelo excesso de leis (não cumpridas ou cumpridas por conveniência) e tímidas iniciativas de se conquistar os consumidores através de um processo sistemático de aproximação e transparência de atitudes empresariais.

Vale ressaltar, também, que este despreparo, mencionado anteriormente, pode estar associado ao processo de modernização de nossas instituições , ainda em fase inicial de desenvolvimento.

Há, no entanto, um movimento de maior distribuição do poder político, abrindo portas para a democratização da sociedade e, enfim, esta democratização impõe a existência de diversas instâncias onde a participação do cidadão se torna imprescindível. É a única forma da democracia representativa compartilhar com a sociedade organizada, a responsabilidade pela condução dos interesses coletivos.

Segundo BOBBIO (1992, p. 56), "existem alguns sintomas encorajadores e outros nem tanto. Ao lado da necessidade de autogoverno existe o desejo de não ser de fato governado, de ser deixado em paz. O efeito do excesso da politização pode ser a revanche do privado". Está presente, portanto, a dicotomia público/privado a partir da qual questiona-se a necessidade da intervenção estatal na regulação dos comportamentos dos indivíduos em contrapartida a liberdade de comprar, de vender e de fazer outros contratos um com outro (HOBBES, 1651 apud BOBBIO, 1995), características fundamentais do privado e do livre mercado. 
No entanto, o cidadão ao cultivar o seu "particular" pode caminhar para o indiferentismo em relação as questões de ordem pública. Também Rousseau estava completamente ciente do fato, concluiu BOBBIO (1992, p.57): "Tão logo o serviço público deixa de ser a principal ocupação dos cidadãos e eles preferem servir com sua bolsa e não com sua pessoa, o Estado já se encontra próximo de sua ruína".

O que se poderia afirmar, a partir das reflexões até aqui estabelecidas e ao ser abordada a dicotomia público/privado, é que a evolução das transformações da indústria de energia elétrica no Brasil dependerá de um amplo processo de amadurecimento sócio-político onde será fundamental a participação do público consumidor, junto as empresas de distribuição de energia elétrica.

A participação do público consumidor é um processo pelo qual uma empresa de distribuição de energia elétrica pode consultar ou incluir pessoas, organizações, órgãos e entidades governamentais nas decisões a serem tomadas.

O processo de participação fornece um meio pelo qual as preocupações, necessidades e valores do público consumidor podem ser identificados antes das decisões, para que estas reflitam - até onde possível, dadas as limitações financeiras, legais e técnicas - os pontos de vista dos consumidores.

Quando a participação for bem sucedida, isto resulta em uma melhor compreensão pela empresa das necessidades e preocupações públicas e também resulta na educação do público com relação aos problemas e dificuldades empresariais. A participação do público é uma comunicação bilateral, sendo decisões melhores e mais bem aceitas.

A participação pública, como definido aqui, faz mais do que apenas informar o público, ela solicita respostas relacionadas às necessidades, valores e 
avaliações das medidas ou soluções propostas visto que as pessoas precisam de informações para avaliar, de maneira inteligente, as alternativas. Informar o público é ainda uma tarefa essencial para qualquer programa de participação. Mas a medida definitiva do sucesso de tal programa é se o público consumidor considera que as decisões das empresas respondem às suas preocupações.

De forma típica, o processo de participação do público consumidor envolve o uso de diversas técnicas, incluindo entrevistas, seminários, grupos de consultoria, conselhos de consumidores, folhetos informativos, reuniões e audiências públicas. Tais atividades em andamento podem garantir a compreensão contínua das empresas sobre diversas questões de preocupação do público.

Os chamados Serviços de Utilidade Pública exercem uma dependência absoluta no dia a dia das comunidades. Desde o uso da água doméstica, o transporte coletivo, o envio de uma correspondência e o acionamento de uma lâmpada elétrica estamos sendo atendidos por uma empresa de serviços de utilidade pública. $O$ fornecimento desses serviços, na quantidade suficiente, com qualidade adequada e a preço acessível, é de fundamental importância para a satisfação do público consumidor.

A definição de "Serviço Público" obtida em MEIRELLES (1989, p. 289), diz o seguinte: "Serviço Público é todo aquele prestado pela administração ou por seus delegados, sob normas e controles estatais, para satisfazer necessidades essenciais ou secundárias da coletividade ou simples conveniências do Estado."

Ainda, segundo o mesmo autor, vemos que se levarmos em conta a essencialidade, a adequação, a finalidade e os destinatários dos serviços, podemos, ainda, distinguir os serviços públicos, dos serviços de utilidade pública. Serviços públicos, propriamente ditos, são os que a Administração presta diretamente à comunidade, sendo essenciais e necessários para a sobrevivência 
do grupo social e do próprio Estado. São exemplos desses serviços, os de defesa nacional, os de polícia, os de preservação da saúde pública.

Em contrapartida, ainda segundo o autor, os serviços de utilidade pública são os que a Administração, reconhecendo sua conveniência para os membros da coletividade, presta-os diretamente ou autoriza que sejam prestados por terceiros (concessionários, permissionários ou autorizatários), em condições reguladas e sob seu controle, mas por conta e riscos dos prestadores. São exemplos desses serviços, os de transporte coletivo, energia elétrica, gás, telefone.

Ainda, segundo MEIRELLES, o serviço público visa satisfazer as necessidades gerais e essenciais da sociedade e o serviço de utilidade pública objetiva facilitar a vida do indivíduo na coletividade, pondo à sua disposição utilidades para o seu conforto e bem-estar. Conclui, ser o primeiro (serviço público), pró-comunidade e o segundo (serviço de utilidade pública), pró-cidadão.

No entanto, a legislação recente aborda a questão do serviço público, de uma forma abrangente, estando definido que a concessão de um determinado serviço público é a transferência da prestação desse serviço, por delegação contratual, feita pela Administração a terceiro, que irá executá-la por prazo certo e por sua conta e risco, mediante remuneração cobrada do usuário, ou seja a tarifa, conforme Lei 8987 , de 13.02.97.

As primeiras preocupações com o tema "Serviço Público", foram desenvolvidas pelos norte-americanos, nas décadas de 20,30 e 40, e desenvolveram uma variada literatura sobre as "Public Utilities", principalmente porque a tradição liberal dominante nos Estados Unidos, exigia justificativa jurídica e econômica bem fundamentadas. Essa preocupação é sentida nas inúmeras publicações de manuais sobre "Public Utilities", que dedicavam uma parte da obra, analisando detidamente os julgamentos da Suprema Corte americana, seguida de 
análises das condições econômicas que reiteravam a necessidade de intervenção no caso específico dos serviços de utilidade pública (JOHNSON et al., 1996).

Ainda, segundo JOHNSON et al. (1996, p. 9): "O caso mais clássico na literatura ocorreu em 1876 em Chicago: a firma Munn e Scott, era a única possuidora de silos de armazenagem de cereais daquela cidade. Tal situação levou-a à elevação dos preços cobrados, gerando uma reação contrária dos usuários. A municipalidade, em defesa dos usuários, impôs tarifas máximas. Munn e Scott recorreram da decisão até na Suprema Corte. Ao argumento da firma de que a municipalidade pretendia privá-la do livre uso de sua propriedade, a Suprema Corte opôs a noção de que aquele negócio envolvia o interesse público por ser essencial ao conjunto da coletividade (confirmando a sentença do Tribunal de Illinóis)".

O conceito de "interesse público" afetado por determinada atividade econômica passou a ser determinante, nos Estados Unidos, como critério para definir a legítima intervenção do Estado na esfera econômica, tendo sido utilizado como referência para definir os chamados "serviços de utilidade pública" e para justificar sua regulamentação e controle pelo Estado.

Numa análise das experiências internacionais, podemos verificar que existem duas vertentes básicas das atividades dos serviços de utilidade pública:

- Modelo norte-americano: é caracterizado pela forte presença de empresas privadas submetidas a algum tipo de regulação e controle por parte do governo.

- Modelo europeu: onde os serviços são prestados por órgão do governo ou por empresas públicas ( com eventual participação do capital privado).

Ressaltamos, que os modelos apresentados não possuem a abrangência geográfica que os nomes sugerem, mas servem para caracterizar as distintas 
formas de organização dos serviços de utilidade pública, como é o caso do Brasil, que possuía um modelo tipicamente americano até 1930, adotando depois um modelo tipicamente europeu, quando os serviços de utilidades pública passaram, progressivamente a serem geridos pelo Estado, pois a iniciativa privada mostrouse incapaz de manter o serviço, especificamente os serviços de energia elétrica, que necessitavam de grandes investimentos, para acompanhar a demanda crescente.

O monopólio natural nos serviços de energia elétrica é causado pelo fato de que a economia de escala na operação e expansão do sistema que serve a muitos clientes tem seus custos decrescentes por unidade quando ele atende a mais clientes, Como exemplo podemos verificar que as grandes empresa tem custos menores que pequenas empresas quando atendem a mesma área (caso Eletropaulo e Elektro em função da densidade atendida para uma mesma área).

Por outro lado verificamos que a duplicação da rede elétrica é muito cara, além do que existe a questão da insuficiência de espaço para multiplicar a distribuição do sistema de distribuição. Um outro aspecto é que a comunidade e as prefeituras não veriam com bons olhos esta duplicidade nas cidades, tendo só como objetivo as oportunidades de negócios que se apresentam às empresas.

Com o desenvolvimento econômico e técnico, um monopólio natural pode deixar de sê-lo. Exemplo disso é a telefonia celular, a prestação dos serviços de segurança etc. Seguramente se as pilhas de energia elétrica associadas ao desenvolvimento da supercondutividade avançarem, inclusive com a redução dos custos, a atividade de distribuição de energia elétrica para uso residencial deixará de ser um monopólio natural. Um outro exemplo é o Franchising nos EUA, onde, apesar da distribuição de energia elétrica ser um monopólio, alguns estados americanos possuem as chamadas "Franchising Area", sendo o serviço franqueado a quem oferecer melhores condições de preço, qualidade etc.. 
A diferença fundamental no ambiente de privatização dos serviços públicos, é que nele atua fortemente o binômio investimento e concorrência. Nesse contexto, no monopólio natural o consumidor não tem opção de escolha, daí a necessidade de regulação.

A importância da energia elétrica para a sociedade, faz com que exista a necessidade de um maior controle, por parte da sociedade, das empresas que geram transmitem e distribuem energia elétrica, pois envolvem uma gama variada de agentes, conforme esquematizado na Figura 2.1 (BORENSTEIN et al., 1997).

Figura 2.1 - Agentes ativos na indústria elétrica

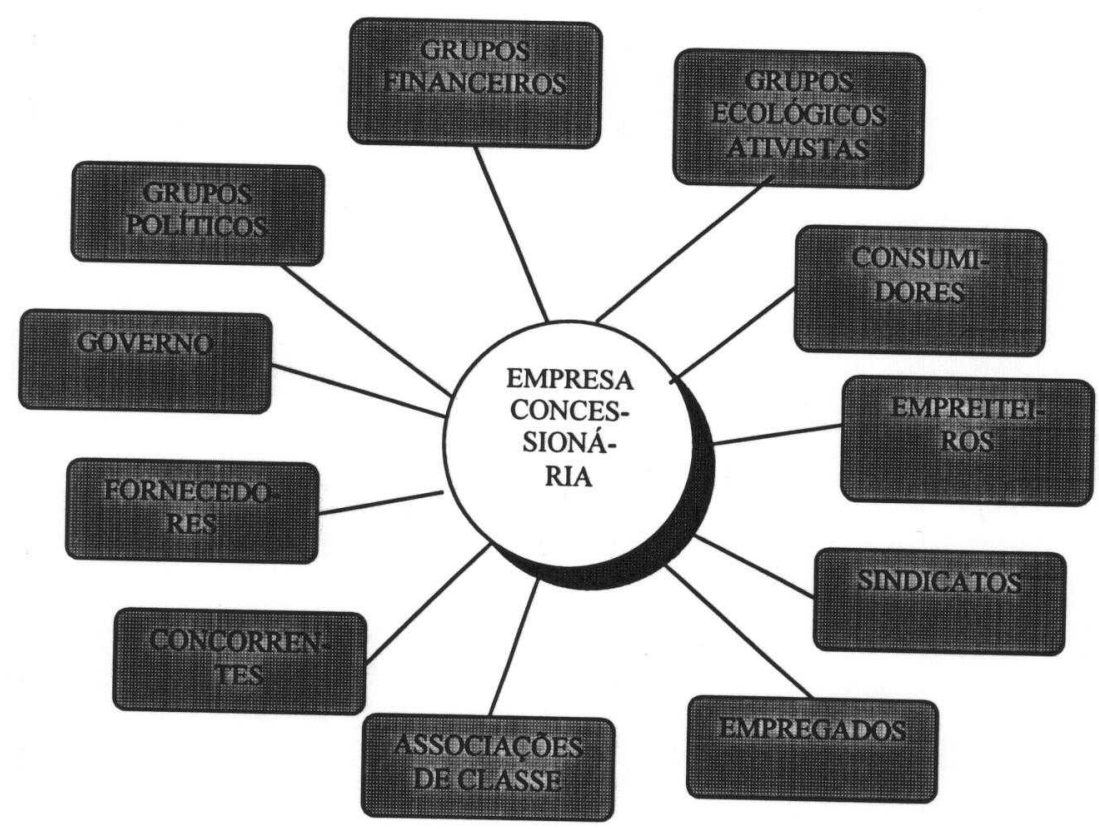

A regulação torna-se muito importante, efetiva e necessária quando o poder está baseado na disponibilidade de recursos, conhecimento privilegiado ou a ausência de competição, como no caso do monopólio natural, senão haverá o desequlíbrio entre o serviço e o consumidor. Ela é ainda útil quando as chamadas externalidades tornam-se nocivas à sociedade e podem ser atribuídas a corporações específicas. Uma das funções da regulação é democratizar a organização, sem destruir a sua eficiência. 
O contexto da regulação, no sentido de influenciar os resultados empresariais, nos remete a questão do poder das organizações. Nesse sentido denomina-se Poder Organizacional ao exercido pela organização sobre a sociedade. Verifica-se que, o poder das organizações tem crescido em relação à sociedade. Em contrapartida, tem crescido, igualmente, na sociedade movimentos para reequilibrar esta relação. Uma maior articulação dos agentes envolvidos visando influenciar no processo regulatório e a própria organização dos grande grupos econômicos atestam esses fatos. Existem 3 razões para tal crescimento:

- o poder econômica tornou-se concentrado;

- $\quad$ o aumento do poder econômico no setor privado e na grandes corporações levou a um acréscimo significativo nas suas conseqüências sociais;

- a expectativa da população em relação ao comportamento econômico e social destas organizações cresceu significativamente nos últimos anos ( $p$. ex., com o fim da demanda reprimida, as exigências de qualidade tornam-se cada vez maiores)

O poder das organizações pode se dar no contexto econômico, social e cultural, técnico, ambiental e político, contrapondo-se, portanto a regulação do seu comportamento junto a sociedade, conforme esquematizado na Figura 2.2 (BORESTEIN et al.,1997).

Figura 2.2 - Poder organizacional e sociedade

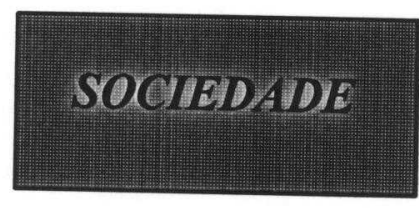

PODER ORGANIZACIONAL

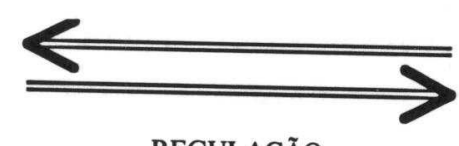

REGULAÇÃo

\section{ORGANIZACAO}

Daí, a necessidade do Estado, com seus instrumentos, promover o processo de regulação e controle da organização, buscando o equilíbrio dos interesses envolvidos. 
É evidente que dependendo do grau de amadurecimento sócio-político da sociedade e de seus cidadãos, o poder do Estado pode abrandar ou aumentar, de acordo com a concepção dos poderes políticos constituídos.

Na Babilônia, há mais de 4.000 anos o código de Hamurabi já estabelecia regras para a atividade mercantil. Na Grécia antiga e no Império Romano, foram concebidas as regras básicas de muitos códigos comerciais e de direito civil da civilização ocidental. Desde então, a intervenção do Estado na atividade das organizações foi-se ampliando, a ponto que entre os séculos 13 e 16 todas as atividades comerciais e industriais estavam sujeitas a regulação específica.

Regular significa sujeitar as regras, dirigir. A regulação portanto é a interferência nas atividades, no caso operação, distribuição, comercialização, tarifação de energia elétrica, determinando o comportamento a ser governado, alterado, controlado, guiado. Regular não é substituir a atividade, mas sim dirigí-la, não sendo portanto a regulação parte da atividade ou envolvida na sua realização. Ela participa das atividades de forma indireta, eventualmente até fazendo uma restrição intencional na atividade regulada, as vezes por uma entidade externa não envolvida diretamente nas atividade do regulado.

Portanto a regulação pode ser encarada como um processo entre o regulador e o regulado, em que o primeiro procura restringir a escolha do primeiro, e este, sofrendo a restrição, vai agir ou reagir em resposta a esta restrição. Portanto existe uma relação de poder entre os envolvidos.

A função precípua da regulação é a defesa do interesse público, que as vezes a coloca como protetora dos menos favorecidos. Ela pode ser exercida com o objetivo de :

- proibição de determinados comportamentos, vedando e impedindo a realização de certas ações expressas nos objetivos das regulações; 
- mediação, atuando como um filtro entre o público e o privado, evitando muitas vezes o conflito direto entre as partes, num processo de troca através de sua atividade reguladora;

- promoção, incentivando certos comportamentos através de benefícios ou estabelecendo programas de fomento e atendimento a carências regionais.

- Muitas vezes a intervenção regulatória é estabelecida pela necessidade de proteção do público. È muito comum a captura do órgão regulador pelo regulado, que passa a influenciar nas decisões do regulador, tornando interessante ao regulado a manutenção do status quo, tendo uma ação equivalente a um cartel sendo o controle exercido por um órgão governamental e não por um conselho de organizações privadas.

Algumas conseqüências da regulação podem assim serem resumidas:

- fornecimento de forma fácil de subsídios diretos;

- barreira para entrada de competidores e até a entrada de concorrentes, quando essa for uma política nacional;

- dificuldades de entrada de produtos com restrições;

- fixação artificial de preços, coordenando e gerenciando a competição, beneficiando empresas ineficientes em detrimento do consumidor.

- Pode servir para o estabelecimento de regras em benefício da segurança e bem estar dos cidadãos, controle da poluição, estabelecendo normas de segurança no transporte, e obrigando o fabricante/produtor a arcar com o custo social dos produtos que produz;

- estabelecer direitos do consumidor, frente ao fabricante e garantia de amparo legal, ressarcimento por eventuais problemas com a aquisição destes produtos ou serviços;

Em contrapartida, alguns problemas da regulação podem ser expressos como segue: 
- a regulação pode impor restrições genéricas, não distinguindo as vezes organizações com um comportamento social adequado daquelas com comportamento social inadequado;

- geralmente a aplicação e a administração da regulação não é uma tarefa fácil, exigindo períodos de adaptação do regulador, pressões sociais, de grupos econômicos organizados, ações judiciais ou ainda impossibilidade de aplicação prática;

- a regulação pode carregar consigo um aspecto de conservadorismo intrínseco, seja por radicalismo, seja por incompreensão que vai onerar economicamente ou socialmente aquele a que se quer proteger. 


\section{A INDÚSTRIA DE ENERGIA ELÉTRICA NO BRASIL}

A utilização da energia em sua forma elétrica como mercadoria se deu no decorrer da segunda Revolução Industrial ao final do século passado. A partir de meados do século XIX, a eletricidade deixa de fazer parte, apenas da curiosidade científica, evoluindo para uma seqüência de usos comerciais (ALMEIDA, 1980).

Thomas Edison, com a demonstração da lâmpada incandescente em 1879, possibilitou um enorme desenvolvimento da indústria de energia elétrica. Pode-se dizer que este foi o marco do surgimento da indústria de material elétrico. Com a utilização em escala crescente de lâmpadas elétricas viabilizou-se esse setor industrial, constituído pela geração, transmissão e distribuição e comercialização de energia elétrica e como consequência a indústria de material elétrico.

A utilização comercial de energia elétrica a partir de então propiciou o surgimento da indústria de material elétrico com forte impacto nos setores que se utilizavam da eletricidade em seus processos industriais.

A partir da formação das primeiras empresas do ramo, tais como a General Electric Company (GE), precedida pela criação durante a década de 1880/90 da Edison General Electric, pelo próprio Thomas Edison, já se observou claramente a concentração e a cartelizaçao da indústria (ALMEIDA , 1980).

O desdobramento da indústria de material elétrico, ocorreu tanto nos Estados Unidos, como na Europa baseado no monopólio tecnológico e no estabelecimento de filiais em outros países.

Verificou-se, portanto, que a rápida diversificação das empresas líderes baseou-se no monopólio tecnológico da produção e utilização de energia elétrica, mantendo uma estrutura extremamente oligopolizada a nível internacional através de vários tipos de acordos e licenciamentos mútuos. 
No entanto, uma das mais importantes vantagens das empresas que lideravam os mercados domésticos de equipamento, consistiu na montagem de um sistema de financiamento de suas vendas. Esta vantagem foi traduzida por uma estrutura de financiamento de equipamentos, tendo como cliente final companhias concessionárias.

Portanto, conforme afirma ALMEIDA (1980, p.13) “... a formação das concessionárias de energia elétrica, várias economias periféricas, em particular o Brasil, seria apenas um prolongamento marginal dos arranjos e acordos do oligopólio internacional de equipamentos elétricos".

\subsection{EVOLUÇÃO HISTÓRICA}

\subsubsection{Os primórdios da indústria de energia elétrica no Brasil - até 1930}

\section{a. A presença do Estado}

A interferência do Estado na indústria de energia elétrica durante a República Velha resumiu-se a medidas isoladas na regulamentação desses serviços. A Constituição Federal de 1891 reforçou o caráter eminentemente local da implantação e do desenvolvimento do parque elétrico.

Ao final de 1903, o orçamento da União incluía a disposição do governo em promover $\circ$ "... aproveitamento da Força Hidráulica para transformação em energia elétrica aplicada a serviços federais ..." (Lei 1145, de 31/12/1904).

Em 1904, aprovou-se o decreto 5407 que regulava a determinação anterior. Essa última medida procurava estabelecer as regras para os contratos de concessão de aproveitamento hidroelétrico aplicado a serviços federais: em primeiro lugar, o prazo da concessão seria no máximo de 90 anos, findo o qual as instalações reverteriam em benefício da União; em segundo lugar, a tarifa fixada 
em cada contrato seria revista ao final do terceiro ano de fornecimento e daí por diante a cada cinco anos, podendo também ser reduzida sempre que os lucros líquidos da concessionária superassem a remuneração anual de $12 \%$ sobre o capital aprovado pelo Governo (LIMA, 1984).

Considerado o embrião da legislação brasileira o decreto 5407 teve, na prática, um efeito muito reduzido, em relação às tarifas. Os contratos de concessão celebrados com o Grupo LIGHT, por exemplo, abriam a possibilidade de reduzir drasticamente o período de revisão, pois previam a aplicação da chamada cláusula-ouro, isto é, o pagamento pelo serviço prestado de metade em papel moeda e a outra metade em valores-ouro, ao câmbio médio do mês de consumo.

Conforme afirma LIMA (1984, p. 17): "Os contratos de concessão definiram a natureza e o regime de exploração dos serviços de eletricidade até a década de 1930. A União, com base na Constituição de 1891 , remetia às esferas estadual e municipal a competência para firmar tais contratos.... Dada a pequena dimensão do sistema nessa fase, a exploração desses serviços só poderiam atender aos interesses estritamente locais, municipais. Desta forma, pode-se identificar nos municípios o verdadeiro poder concedente desses serviços públicos, cuja exploração ficava à mercê do relacionamento entre as prefeituras e os concessionários locais".

A tentativa de revisão desse quadro institucional ocorreu em 1906, quando o então Presidente Afonso Pena desencadeou a organização das bases do Código Rural e Florestal e dos de Mineração e Águas da República. O jurista Alfredo Valladão foi encarregado de elaborar as bases para o Código das Águas da República, documento apresentado ao Congresso Nacional em 1907 (LIMA, 1984). 
Entretanto, como afirma LIMA, o projeto do Código de Águas de 1907 não foi à frente. Após longas discussões no Congresso, o projeto estancou na Câmara dos Deputados de 1923 a 1930. Em todo esse período de tramitação, destacou-se apenas a criação da Comissão de Estudos de Forças Hidráulicas em 1920 e a taxação dos serviços de eletricidade através de imposto, em 1923.

\section{b. A entrada do capital estrangeiro no Brasil}

A participação do capital estrangeiro no início da indústria de energia elétrica se dá, por praticamente dois grupos empresariais: o Grupo LIGHT, canadense e o Grupo AMFORP, americano atendendo aos mercados mais promissores, enquanto que as concessionárias nacionais e as outras empresas estrangeiras atendiam a mercados consumidores localizados em regiões menos desenvolvidas economicamente (VIANNA, 1991).

Em 1899, em Toronto, Canadá, foi criada a Empresa São Paulo Railway Light and Power Company Limited, ou Grupo LIGHT, como se tornou conhecida.

Em 17 de julho de 1899, o Grupo LIGHT recebeu autorização do Presidente Campos Sales para que sua subsidiária atuasse no país. Sendo assim, o Grupo Light deixaria de operar com serviços de transporte ferroviário, oferecendo, além da geração de energia elétrica, serviços de transporte urbano de tração elétrica.

Em 1905, o Grupo Light através da empresa Tramway Light and Power passa a operar no Estado do Rio de Janeiro, onde se localizava o maior centro urbano do país, consequentemente, com grande demanda de energia elétrica.

Em pouco tempo, o Grupo LIGHT tornar-se-ia monopolista do fornecimento de energia elétrica no Rio de Janeiro, através do aumento da geração própria de eletricidade, somado à estratégia de incorporação de diversas pequenas empresas privadas. 
Pouco antes do final de 1910, a LIGHT criaria, também com sede em Toronto, a São Paulo Electric Co.. Esta nova empresa serviu de instrumento para a entrada do Grupo Light no interior de São Paulo, e através da compra de empresas regionais, a Light estendia gradativamente seu raio de atuação.

Em 1912, as três empresas: São Paulo Light, Rio Light e São Paulo Electric Co., seriam reunidas na holding Canadá Brazilian Traction, Light and Power, Co. Ltd., onde cada empresa mantinha sua identidade jurídica. Ressalte - se que o domínio da LIGHT já não era canadense a essa época, mas inglês, estreitamente articulada aos bancos de negócios. A LIGHT não deve ser entendida simplesmente como uma empresa estrangeira de energia elétrica que se instalou no Brasil, mas sim como parte integrante de um vasto conglomerado financeiro e industrial (ELETROBRÁS, 1988, apud VIANNA, 1991).

$\mathrm{Na}$ segunda metade dos anos 20 , surgiu um outro grupo estrangeiro na indústria elétrica brasileira: o Grupo AMFORP. Criada nos Estados Unidos em 1923, a American \& Foreign Power Company - AMFORP, era uma subsidiária da norte - americana EBASCO - Electric Bond and Share Company, com a finalidade de centralizar as atividade desta empresa no exterior. Em setembro de 1927 foi criada a holding do Grupo - Empresas Elétricas Brasileiras - , que viria posteriormente chamar Companhia Auxiliar de Empresas Elétricas Brasileiras CAEEB, em vista da necessidade de controle e centralização das atividades que estavam dispersas pelo país.

Não podendo atuar no eixo metropolitano Rio - São Paulo, área de concessão da LIGHT, o Grupo AMFORP incorporaria, até 1930, diversas concessionárias no interior paulista.

Dessa forma, como afirma LIMA (1994), já se podia notar claramente a divisão de mercado entre os Grupos LIGHT e AMFORP: enquanto aquela passou 
a dominar a região entre o Vale do Paraíba e Campinas, a AMFORP estendeu seu domínio a partir de Campinas ( inclusive ), em direção ao norte e noroeste do Estado, por meio da compra da Companhia Paulista de Foça e Luz, do Grupo Armando Salles de Oliveira e de inúmeras outras empresas de âmbito municipal.

Ainda, nesse particular, salienta, BRANCO ( 1975 ): "A Light and Power e a Bond and Share formaram assim suas holdings no Brasil. A primeira comprando todas as empresas existentes entre Jundiaí e Rio de Janeiro, e a segunda, quase todas as do interior do estado de São Paulo “.

Contando com recursos para investir, detendo Know how técnico e administrativo, gerando, transmitindo e distribuindo eletricidade para as principais cidades do país, as empresas de capital estrangeiro chegariam a ter participação expressiva, na década de 30 , na indústria de energia elétrica brasileira.

Assim, em 1930, praticamente todas as áreas mais desenvolvidas do país e também aquelas que representavam maiores possibilidades de desenvolvimento, caíram sob o virtual oligopólio das duas grandes empresas estrangeiras.

O que ficou fora do alcance da LIGHT e da AMFORP era pouco expressivo. De um modo geral, os Estados das regiōes do Norte e Nordeste, os mais pobres das Federação, certamente não ofereciam nenhum atrativo especial de investimento para as duas companhias.

\subsubsection{A era Vargas e o Código de Águas}

A crise econômica de 1929 e a Revolução de 1930 provocaram profundas transformaçōes na estrutura política e econômica do país, responsáveis por fundamentais reformas da administração pública. Essas reformas fortaleceram o Poder Central em detrimento do dos estados (LEITE, 1997). 
A Revolução de 1930, que conduziu Getúlio Vargas ao poder, assinalou, portanto, a queda do regime oligárquico da Primeira República, marcando o início de uma nova etapa da história do país e abriu caminho para profundas transformações em todos os setores da vida nacional, inclusive em energia elétrica (ARANHA, 1991).

A reordenação Institucional do Setor de Eletricidade começou de fato em 1931, quando foram suspensos todos os atos de alienação ou transferência de qualquer curso perene ou queda d'água. Foi o primeiro passo para a afirmação da União como Poder Concedente em matéria de energia elétrica. Nesse sentido, a medida tendia a refrear o intenso processo de concentração do Setor Elétrico verificado na segunda metade da década de 1920, comandado pelos grupos LIGHT e AMFORP.

Em 1934, quase simultaneamente com a nova Constituição, surgiu o Código de Águas, constituindo-se em um marco fundamental na legislação da indústria de energia elétrica introduzindo modificações substanciais na sistemática dos aproveitamentos hidrelétricos (CALABI, 1983).

Destacam-se os seguintes pontos:

- separou a propriedade das quedas d'água, daquela das terras em que se encontram, incorporando-as ao patrimônio da Nação;

- atribui à União a competência de outorga de autorização e concessão para o aproveitamento da energia elétrica para uso privado ou de serviço público;

- instituiu o princípio de custo histórico e do "serviço pelo custo" de lucro limitado e assegurado ;

- iniciou a nacionalização dos serviços, restringindo sua concessão a brasileiros ou empresas organizadas no país. Ressalvou, no entanto, os direitos adquiridos. 
Em 1939, Getúlio Vargas criou, pelo decreto-lei 1.285, o Conselho Nacional de Águas e Energia, transformado, no mesmo ano, em Conselho Nacional de Águas e Energia Elétrica (CNAEE). Com a instituição do CNAEE, o governo objetivava a regulamentação do Código de Águas e promover o desenvolvimento do setor elétrico. O CNAEE ficou diretamente subordinado à Presidência da República, à exemplo dos inúmeros organismos criados após 1937 (LEITE, 1997).

\subsubsection{A formação da indústria de energia elétrica nacionalizada}

A década de 40 se caracterizou pelas divergências entre aqueles que eram favoráveis à nacionalização do setor elétrico e aqueles que defendiam o capital estrangeiro e o liberalismo (RODRIGUES \& DIAS, 1992).

O pós-guerra foi marcado pela crescente urbanização da população brasileira, com o consequente avanço da indústria, do comércio e dos serviços. Nesse momento, os serviços de eletricidade deterioraram-se e instalou-se a crise de energia elétrica no país, passando o racionamento a ser prática corrente ao longo de toda a década de 50 e anos iniciais da seguinte. Destacaram-se os seguintes motivos, segundo LEITE, 1997:

- os impactos da nova legislação de 1934 e da Constituição de 1937 no quadro institucional do país;

- o longo período de dificuldade de importações e a fragilidade do parque industrial nacional para suprir os equipamentos necessários à manutenção e expansão dos serviços;

- a alta inflação no período.

A questão da energia elétrica torna-se o tema central da grande discussão nacional. Os governos se sucedem tomando medidas paliativas, pressionados por duas correntes opostas: a associativa (privatista) que, por princípio, rejeita a intervenção direta do Estado na produção de bens e serviços, e a nacionalista, que condenando a atuação das empresas estrangeiras, reivindica a 
intervenção do Estado e a própria encampação dessas empresas (RODRIGUES \& DIAS, 1992). Ao longo das divergências entre essas duas correntes, os Governos Federal e dos Estados se aliam na reorganização do sistema elétrico em bases estatais.

Inicialmente surgiu a CHESF, em 1945, a fim de promover o aproveitamento do rio São Francisco, para fornecer energia ao esforço nascente de industrialização do Nordeste. Ás Centrais Elétricas de Minas Gerais S/A - CEMIG, fundada em 1952, foi a primeira empresa estadual de economia mista a ser criada no Brasil, para realizar o Plano Global de Eletrificação, pois, até a sua criação, o serviço de energia elétrica do estado baseava-se em um sem número de pequenas empresas que atendiam a centenas de localidades e a numerosas indústrias de pequeno porte.

O processo de criação da CESP - Companhia Energética de São Paulo, foi bem diferente. Até 1950, a São Paulo Light e a Companhia Paulista de Força e Luz - CPFL, eram as detentoras do fornecimento para a maior parte do território paulista. Contudo, o crescimento da demanda de energia elétrica provocava a sobrecarga dos sistemas, em virtude dos reduzidos investimentos realizados pelas concessionárias.

O Governo do Estado de São Paulo decidiu, então, entrar no Setor, iniciando em 1949, o aproveitamento do rio Paranapanema, área fora das concessões dos dois grupos e, mais tarde, em 1953, criando a Usinas Elétricas do Paranapanema - USELPA. Em 1951, organizou o Departamento de Águas e Energia Elétrica DAEE e no ano seguinte a Comissão Interestadual da Bacia do Paraná - Uruguai CIBP. O DAEE dedicou-se, inicialmente, a executar um plano de aproveitamento do rio Tietê e a CIBPU empreendeu estudos no rio Paraná, fazendo o levantamento das corredeiras de Urubupungá, dos quais resultou, mais tarde, o grande complexo de llha Solteira e Jupiá. Para a construção das duas usinas foi 
criada pelo Governo de São Paulo a CELUSA - Centrais Elétricas Urubupungá S.A. .

A conveniência de um planejamento estadual que reunisse as várias empresas estaduais em uma só, resultou na criação da CESP. Foram incorporadas a CELUSA, a USELPA, a CHERP, a BELSA (Bandeirantes de Eletricidade S/A) e a COMEPA (Companhia de Melhoramentos do Paraibuna) e ainda diversas empresas menores.

Furnas foi criada em 1957 pela necessidade do Governo Federal ingressar no campo de produção de energia elétrica na Região Centro-Sul do país, a fim de superar a crise de suprimento que já era sentida e tendia a agravar-se no maior centro econômico do Brasil.

No Rio Grande do Sul, em 16.02.43, foi criada a Comissão Estadual de Energia Elétrica - CEEE, com a finalidade de prover um plano geral para todo o Estado e o aproveitamento do seu potencial hidráulico, em conexão com as reservas carboníferas.

No setor privado, além das duas grandes empresas do Grupo Light (Rio e São Paulo) e das Companhias que integravam a CAEEB (Grupo AMFORP), a participação do Setor dos Serviços Públicos de Eletricidade limitava-se, no início dos anos 60, a um número reduzido de pequenas empresas de capital nacional, concentradas no Sudeste e no Sul do País.

A criação desse grande elenco de empresas estaduais, seguida da execução simultânea de obras de vulto e de longa maturação, exigindo orçamentos plurianuais de investimentos, evidenciou, desde cedo, que tais programas não poderiam ser executados apenas com dotações orçamentárias. Por outro lado, a demanda de participação financeira federal, mesmo em programas estaduais, indicava a necessidade de uma coordenação, a nível nacional, a fim de 
contabilizar os diversos empreendimentos programados, não somente entre si, como os mercados consumidores.

Estas empresas estaduais passaram a atuar, como as grandes distribuidoras de energia, de fomento social, totalmente monopolistas, sendo que suas decisões dependiam diretamente dos interesses políticos, muitas vezes em detrimento de opções técnicas mais viáveis. A alternância no poder de grupos políticos diferentes, fatalmente influía na tomada de decisões das empresas estatais, prejudicando dessa forma o processo de solução de continuidade em projetos que em vez de beneficiar toda sociedade, atendia a interesses de grupos ou regiōes politicamente aliadas.

A constituição efetiva da ELETROBRÁs, em junho de 1962, deu início a profundas transformações na estrutura do Setor de Energia Elétrica. Essas mudanças se fizeram sentir sobretudo a partir da segunda metade da década de 1960. O planejamento do Setor, até então regional e assistemático, foi adquirindo uma feição mais definida e organizada, tanto institucionalmente, quanto em termos hierárquicos.

Com o movimento revolucionário de 1964, o Governo Federal criou uma comissão interministerial, sob a coordenação do presidente ELETROBRÁs, que ultimou as negociações para compra das ações pertencentes às concessionárias estrangeiras controladas pela AMFORP. A operação foi aprovada pelo Congresso Nacional em 06.10.64. Oito dias depois foi sancionada a Lei 4.428 e, em 12 de novembro, foi assinado em Washington o tratado de compra e venda das empresas do Grupo Americano.

A partir de 1965, encontramos disposições acerca da estruturação do MME quando a Divisão de Águas do Departamento Nacional de Proteção Mineral (DNPM) se transformou em Departamento Nacional de Águas e Energia (DNAE). Em 1968, com a extinção do CNAEE, o DNAE absorveu suas atribuições, 
passando a ser denominado Departamento Nacional de Águas e Energia Elétrica. (CALABI, 1983). Com essa reforma, teve início a consolidação da estrutura básica do Setor Elétrico no Brasil tendo como seu centro a ELETROBRÁs e o MME Ministério de Minas e Energia, que progressivamente iam se transformando em órgãos coordenadores do Setor de Energia Elétrica.

A partir de então, a política de energia elétrica no país passou a ser traçada pelo Ministério das Minas e Energia e executada pela ELETROBRÁs. financiando, coordenando e supervisionando os programas de construção, ampliação e operação dos sistemas de geração, transmissão e distribuição de energia elétrica, assistindo técnica e administrativamente suas empresas controladas e coligadas, promovendo o desenvolvimento global do Setor.

Consolida-se, portanto, um esquema de financiamento do setor, tanto ao nível fiscal, como a nível de capacidade de autofinanciamento das empresas. Estas condições promoveram um processo de expansão contínua do setor(CALABI, 1983).

\subsubsection{O período pós-1973}

A crise do petróleo, em 1973 trouxe mudanças significativas no quadro institucional e nas relações e responsabilidades dos agentes do setor elétrico. Uma modificação das mais relevantes é que sob o argumento da necessidade de fortalecer a interconexão dos sistemas, promoveu-se a equalização tarifária.

Até 1974, as tarifas de energia elétrica eram diferenciadas por regiōes, levando-se em conta o custo de serviço de cada empresa (RODRIGUES \& DIAS, 1994).

Segundo LEITE (1997), vinha de longe a idéia da utilização do poder de fixação das tarifas como instrumento ora demagógico, como no caso da 
equalização, ora de política antiinflacionária, inclusive com intensa disputa entre o MME e o Ministério da Fazenda e Seplan em 1969, resultando na preservação do poder aquisitivo da tarifa, até 1975, quando se deu nova intervenção dos ministérios da Fazenda e do Planejamento. Tal intervenção está explicitado no Decreto no. 79.706 , de 18 de maio de 1977, que estabelecia que o ato de fixação de qualquer preço, ou tarifa, por órgãos ou entidades da administração federal, direta ou indireta, mesmo nos casos em que o poder para tal fixação seja decorrente de lei, dependeria, para sua publicação efetiva, de prévia aprovação do Ministro de Estado Chefe da Secretaria do Planejamento.

Ainda, segundo LEITE, enquanto o Brasil deixava cair as tarifas, a maioria dos países adaptava-se à nova conjuntura, reconhecendo a elevação real do custo da energia e a necessidade de modificações da estrutura de preços relativos dos energéticos em geral. Nesse sentido, os governos militares, de então, sinalizavam o barateamento da energia elétrica desestimulando os esforços para sua conservação.

É bem verdade, que em 1973, como afirma LEITE, a tarifa residencial encontrava-se exageradamente alta, principalmente se levado em conta o baixo nível de renda da maioria dos consumidores. Justificou-se, portanto, como parte de uma política social, a concessão, em 1978 o desconto de $30 \%$ nas tarifas aplicáveis aos consumidores residenciais nos primeiros $30 \mathrm{kwh}$ de consumo. Em 1985, foram estabelecidos descontos significativamente elevados, atingindo consumidores de maior poder aquisitivo. Misturavam-se questões econômicas e sociais dentro do contexto da equalização tarifária, num momento em que ocorria - segundo choque nos preços do petróleo, a alta de juros no mercado internacional, da inflação americana e da inflação brasileira.

Os fundamentos do quadro institucional do setor de energia elétrica mantiveram-se estáveis durante um longo período, que compreendeu, todavia, uma fase de aperfeiçoamento e consolidação e outra de deterioração. Um 
processo de intensas modificações, iniciou-se com a Constituição de 1988. Algumas disposições constitucionais tiveram intensa repercussão no quadro institucional do setor de energia elétrica como mostrado a seguir:

Artigo 175: Incumbe ao Poder Público, na forma da lei, diretamente ou sob regime de concessão ou permissão, sempre através de licitação, a prestação de serviços públicos.

Este artigo cancelou todas as concessões vigentes para aproveitamentos hidrelétricos que não estavam implantados no país, e desencadeou discussão abrangente sobre a regulamentação das concessões, somente concluída em julho de 1995, com a caracterização, também, do produtor independente.

Os artigos 153 e 155 determinaram o fim dos impostos únicos, que estavam vinculados à aplicação dos recursos arrecadados em alguns setores.

Desde o final da década de 80 já se falava no processo de privatização dos serviços de eletricidade, até então sob o controle do Estado. Esse processo tinha como objetivo, reduzir a presença do Estado como agente econômico direto e também era motivado pela interferência política na administração das empresas e pela incapacidade dos governos em proverem investimentos necessários no setor (LEITE, 1997). Nessa época o setor elétrico figurava como o responsável pelo atendimento de $87 \%$ das residências, constituindo-se no serviço público mais abrangente do país (ELETROBRÁs, 1991).

Instalou-se nesse período, intensas discussões a respeito dos novos rumos do setor elétrico nacional, dentro do programa Revisão Institucional do Setor Elétrico - REVISE, envolvendo ampla gama de agentes. As discussões no Congresso, não sinalizavam convergência, prevalecendo o jogo de forças regionais. 
Em março de 1993, a partir da Lei no. 8.631, foi dado importante passo que modificou o sistema tarifário, determinando o fim do serviço pelo custo com remuneração garantida e o fim da equalização tarifária, além do equacionamento das dívidas intrasetoriais.

Em setembro de 1993, outro dispositivo legal, o Decreto no. 915, permitiu a formação de consórcios entre concessionários e autoprodutores para exploração de aproveitamentos hidrelétricos e construção de usinas. Ainda, neste mesmo ano, foi instituído o Sistema Nacional de Transmissão de Energia Elétrica SINTREL, com o objetivo de possibilitar o intercâmbio de energia entre concessionários e produtores independentes ${ }^{1}$

A Lei no. 8987, de fevereiro de 1995, complementada pela Lei 9074, de julho de 1995 regulamentou o art. 175 da Constituição Federal, concluindo importante etapa legislativa do setor, estabelecendo além de outras questões, as normas para outorga e prorrogação das concessões e permissões de serviços públicos e criando a figura do produtor independente.

As modificações iniciadas, de modo geral, vieram favorecer oportunidades operacionais no setor, anteriormente inexistentes. Do ponto de vista econômico, pode-se considerar, que a médio prazo, com a efetivação do processo de privatização e com o surgimento de produtores independentes, o mercado apresentará novidades, que influenciarão, definitivamente o desempenho das empresas.

Ainda, sob os efeitos dos últimos dispositivos legais que mudariam o setor elétrico, o Governo Federal acabou por contratar a consultoria inglesa Coopers \& Lybrand, para propor a reorganização do setor, a ser objeto de reflexão no item 6.1 deste trabalho.

\footnotetext{
${ }^{1}$ Decreto no. 1009, de dezembro de 1993 e portaria no. 337, de abril de 1994 - criam o Sistema Nacional de
Transmissão de Energia Elétrica - SINTREL.
} 


\subsection{CARACTERÍSTICAS GERAIS DA INDÚSTRIA DE ENERGIA ELÉTRICA NO BRASIL}

Segundo a ELETROBRÁS (1996) o serviço público de energia elétrica cobre cerca de $90 \%$ dos domicílios do país, constituindo-se no serviço mais difundido, empregando cerca de 250 mil pessoas. A Tabela 3.1, abaixo, demonstra as grandezas econômicas principais do Brasil relacionando-as a energia.

Tabela 3.1 - Grandezas de energia e economia do Brasil

\begin{tabular}{|c|c|c|c|c|c|c|c|c|c|}
\hline & 1970 & \begin{tabular}{|c|} 
Var. \\
$\%$ \\
$70 / 80$
\end{tabular} & 1980 & $\begin{array}{c}\text { Var. } \\
\% \\
80 / 90\end{array}$ & 1990 & $\begin{array}{c}\text { Var. } \\
\% \\
90 / 94\end{array}$ & 1994 & $\begin{array}{c}\text { Var. } \\
\% \\
94 / 96\end{array}$ & 1996 \\
\hline População (milhão hab.) & $\begin{array}{c}93 \\
-\end{array}$ & $\begin{array}{c}- \\
2,5\end{array}$ & $\begin{array}{c}119 \\
-\end{array}$ & $\begin{array}{c}- \\
1,9\end{array}$ & $\begin{array}{c}143 \\
-\end{array}$ & $\begin{array}{c}- \\
1,9\end{array}$ & $\begin{array}{c}154 \\
-\end{array}$ & $\begin{array}{c}- \\
1,6\end{array}$ & $\begin{array}{c}159 \\
-\end{array}$ \\
\hline $\begin{array}{c}\text { PIB (US\$ bilhões/95) } \\
.\end{array}$ & $\begin{array}{c}238 \\
- \\
\end{array}$ & $\begin{array}{c}- \\
8,6\end{array}$ & $\begin{array}{c}543 \\
-\end{array}$ & $\begin{array}{c}- \\
1, .5\end{array}$ & $\begin{array}{c}630 \\
-\end{array}$ & $\overline{2}$ & $\begin{array}{c}689 \\
-\end{array}$ & $\begin{array}{c}- \\
3.6\end{array}$ & $\begin{array}{c}739 \\
-\end{array}$ \\
\hline US\$/Hab. & $\begin{array}{c}2559 \\
- \\
\end{array}$ & $\begin{array}{c}- \\
6,0\end{array}$ & $\begin{array}{c}4563 \\
- \\
\end{array}$ & $\begin{array}{c}- \\
-0,3\end{array}$ & $\begin{array}{c}4406 \\
- \\
\end{array}$ & 0,4 & $\begin{array}{c}4474 \\
- \\
\end{array}$ & $\begin{array}{c}- \\
1,9\end{array}$ & $\begin{array}{c}4648 \\
- \\
\end{array}$ \\
\hline Milhão tEP & $\begin{array}{c}69 \\
-\end{array}$ & $\begin{array}{c}- \\
6,4\end{array}$ & $\begin{array}{c}128 \\
-\end{array}$ & $\begin{array}{c}- \\
2,8\end{array}$ & $\begin{array}{c}169 \\
-\end{array}$ & $\begin{array}{c}- \\
3.1\end{array}$ & $\begin{array}{c}191 \\
-\end{array}$ & $\begin{array}{c}- \\
3,6\end{array}$ & $\begin{array}{c}205 \\
-\end{array}$ \\
\hline (Cons./PIB) & - & 0,74 & - & 1,87 & - & 1,35 & - & 1,0 & - \\
\hline TEP/Hab. & $\begin{array}{c}0,74 \\
- \\
\end{array}$ & $\begin{array}{c}- \\
3.9\end{array}$ & $\begin{array}{c}1,08 \\
-\end{array}$ & $\begin{array}{c}- \\
0,7\end{array}$ & $\begin{array}{c}1.18 \\
-\end{array}$ & $\begin{array}{c}- \\
1,3\end{array}$ & $\begin{array}{c}1,24 \\
-\end{array}$ & $\begin{array}{c}- \\
2,0\end{array}$ & $\begin{array}{c}1,29 \\
-\end{array}$ \\
\hline Elasticidade (Cons./PIB) & $\begin{array}{l}40 \\
-\end{array}$ & $\begin{array}{c}- \\
11,8\end{array}$ & $\begin{array}{c}122 \\
-\end{array}$ & $\begin{array}{c}- \\
5,9\end{array}$ & $\begin{array}{c}216 \\
-\end{array}$ & $\begin{array}{c}- \\
3,7\end{array}$ & $\begin{array}{c}250 \\
-\end{array}$ & $\begin{array}{c}- \\
5,1\end{array}$ & $\begin{array}{c}276 \\
-\end{array}$ \\
\hline & - & 1,37 & - & 3,93 & - & 1,61 & - & 1,42 & - \\
\hline TWh/Hab. & $\begin{array}{c}430 \\
- \\
\end{array}$ & $\begin{array}{c}- \\
9.1\end{array}$ & $\begin{array}{c}1025 \\
-\end{array}$ & $\begin{array}{c}- \\
4,0\end{array}$ & $\begin{array}{c}1510 \\
-\end{array}$ & $\begin{array}{c}- \\
1,8\end{array}$ & $\begin{array}{c}1623 \\
-\end{array}$ & $\begin{array}{c}- \\
3,4\end{array}$ & $\begin{array}{c}1736 \\
-\end{array}$ \\
\hline
\end{tabular}

Pode-se observar que o consumo de energia elétrica tem crescido acima do PIB e do consumo de energia global. 
O mercado de energia elétrica brasileiro teve seu crescimento acentuado após as crises do petróleo dos anos 70 e 80 . A estratégia governamental da época foi basicamente sustentada pela substituição da dependência externa do petróleo por fontes renováveis de energia. Para o setor de transportes a opção utilizada foi o álcool, produzido a partir da cana de açúcar como substituto da gasolina e para o setor industrial e rural a energia elétrica substituía o óleo. Foram criados então programas de incentivo nestes setores, em alguns casos basicamente subsidiados pelo Governo.

No caso da energia elétrica, em função das sobras de energia, tarifas especiais foram oferecidas a clientes que optavam pela substituição de caldeiras e fornos a óleo por eletricidade. A partir de então o setor aumentava seu nível de endividamento, uma vez que novas usinas, principalmente hidrelétricas, iniciavam suas construções. Enquanto as novas usinas não ficam prontas, e em função do descompasso em relação a infraestrutura entre as regiões do Brasil vários estados, particularmente os do Norte convivem com a fragilidade dos sistemas de transmissão ficando vulneráveis aos racionamentos de energia elétrica.

Segundo a ELETROBRÁS (1997), o consumo e o faturamento de eletricidade no Brasil, em 1997 estão distribuídos conforme Figura 3.1 abaixo:

Figura 3.1 - Distribuição do consumo final de energia elétrica no Brasil - 1997

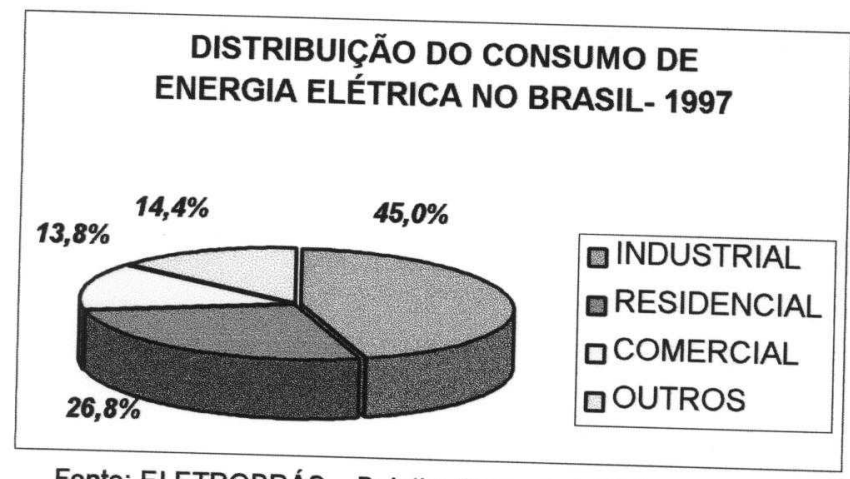

Fonte: ELETROBRÁS - Boletim Semestral, Síntese 1997. 
O reaquecimento econômico proporcionado pelo Plano Real vem provocando um crescimento no consumo de energia, em todas as regiões do país. Em 1997, o mercado total de energia elétrica foi de $277,0 \mathrm{TWh}$, ou seja $6,5 \%$ superior ao ano anterior, sendo $7,3 \%$ na classe residencial, $9,8 \%$ na comercial e $5,0 \%$ na industrial (ELETROBRÁS, 1998) ${ }^{2}$.

A capacidade instalada total de energia elétrica, em 1997, é de 59,3 GW, proporcionando atendimento a cerca de 41,4 milhões de clientes, sendo que mais de 85\% (35,3 milhões) são clientes residenciais (ELETROBRÁS, 1998).

Em agosto de 1998 a produção de energia elétrica no Brasil está estruturada, operacionalmente, a partir de 03 geradoras federais: CHESF, ELETRONORTE e FURNAS, 01 geradora binacional - ITAIPU e geradoras estaduais que acumulam, ora os serviços de transporte de energia, ora os de distribuição. Este panorama encontra-se em plena transformação em razão do processo de desverticalização e privatização em curso.

A Distribuição de energia elétrica é essencialmente desempenhada por 61 concessionárias, sendo $65,6 \%$ (40 empresas) de propriedade privada, $26,2 \%$ (16 empresas) de propriedade dos governos estaduais e $8,2 \%$ (5 empresas) de propriedade das municipalidades ${ }^{3}$ além de inúmeras cooperativas de eletrificação rural, que em alguns casos também atuam atendendo núcleos urbanos.

Os agentes setoriais que atuam na indústria de energia elétrica no Brasil são os seguintes:

\footnotetext{
${ }^{2}$ Sistema de Informações Empresariais do Setor de Energia Elétrica - SIESE/ELETROBRÁS, Boletim
Semestral - Síntese 1997.

${ }^{3}$ Dados obtidos das seguintes fontes:

jornal "A Gazeta Mercantil" de 4 e 5 de abril de 1998, página B-3;

revista "Eletricidade Moderna" no. 280, julho de 1997;

obs. : Os dados foram atualizados para agosto de 1998 em função da evolução das privatizações.
} 
- Ministério das Minas e Energia - MME: é o órgão responsável pela elaboração das políticas referentes ao setor energético, fixando as diretrizes políticas do setor, em concordância com a política energética definida pelo governo.

- A ANEEL - Agência Nacional de Energia Elétrica, sucedânea do Departamento Nacional de Águas e Energia Elétrica - DNAEE, órgão criado em 1968, foi, por longo período o regulador das atividades setoriais, sendo extinto em 1997. A Agência Nacional de Energia Elétrica - ANEEL, órgão criado recentemente será analisada no ítem 6.2.

- A Centrais Elétricas Brasileiras - ELETROBRÁS, desde a sua criação em 1964, exerceu papel fundamental em todo o setor elétrico nacional e deverá Ter seu papel reduzido em função das transformações em curso. Essencialmente, dentre suas funções básicas destacam-se o papel de holding das empresas estatais elétricas e banco de financiamento setorial, além das funções de coordenação do planejamento dos investimentos setoriais e da operação dos sistemas interligados. São os seguintes os comitês coordenados pela Eletrobrás:

- Grupo Coordenador de Planejamento Setorial dos Sistemas Elétricos GCPS, responsável pelo planejamento de longo prazo e pelo programa
decenal de obras do setor elétrico;

- O Grupo Coordenador de Operação Interligada - GCOI, responsável pela definição do regime de operação das unidades de geração que participam dos sistemas interligados Sul-Sudeste e Norte-Nordeste;

- O Conselho de Meio Ambiente do Setor Elétrico - COMASE, responsável por adequar o programa de expansão e o regime de operação interligada à legislação ambiental;

- O Grupo Coordenador para a Conservação de Eletricidade - GCCE, responsável pelas metas definidas pelo Programa de Conservação de Energia Elétrica - PROCEL (ROSA \& OUTROS, 1997). 
Os mesmos autores, destacam outros agentes que surgiram dentro do processo de redemocratização do pais, num movimento de descentralização das decisões, historicamente concentradas na Eletrobrás, tais como: a Associação Brasileira das Distribuidoras de Energia Elétrica - ABRADEE e seus Comitês técnico-operacionais, na qual participam empresas das regiões Sul-Sudeste e do Centro-Oeste; a Associação Brasileira das Concessionárias de Energia - ABCE; a Associação das Empresas de Distribuição de Energia das Regiões, Norte, Nordeste e Centro-Oeste - AEDENNE; E a Associação Brasileira dos Grandes Consumidores de Eletricidade - ABRACE. 


\section{ALGUMAS EXPERIÊNCIAS INTERNACIONAIS DE REGULAÇÃO DOS SERVIÇOS DE ENERGIA ELÉTRICA}

O processo de privatização é provavelmente o fenômeno político e econômico mais importante dessa década, segundo TENENBAUN et al. (1991). O setor de eletricidade, ainda, segundo os autores, cresce continuamente e deverá crescer ainda mais em diversos países, particularmente naqueles em desenvolvimento, como por exemplo nos países da América Latina.

A expansão do uso de eletricidade nesses países se dá em um contexto contrário à capacidade de investimento na infraestrutura elétrica. Os recursos necessários à expansão são limitados na medida em que os países se encontram em situação de elevado endividamento.

As restrições na obtenção de recursos externos agravam a solução dos problemas energéticos desses países. Dessa forma, a privatização da indústria elétrica parece surgir com a expectativa de ser a solução necessária para o desenvolvimento econômico e social (TENENBAUN et al., 1991).

Sugerem, os mesmos autores, a consideração de cinco questões básicas quanto a privatização da indústria elétrica:

1. quais os segmentos dessa indústria devem ser privatizados ?

2. qual deve ser a estrutura da indústria a ser privatizada ?

3. onde e como deve haver a competição ?

4. como deve ser regulada a indústria privatizada?

5. qual método ou processo de privatização deve ser usado ?

Quanto aos modelos de estrutura da indústria elétrica, de forma geral, podem ser assim traduzidos:

Modelo 1: consiste em uma ou mais companhias privadas de eletricidade. verticalmente integradas; 
Modelo 2: complementa a estrutura do modelo 1, com aquisição de geração competitiva. A lei americana de 1978 (PURPA) deu início a esse modelo nos EUA;

Modelo 3: amplia o modelo 2, introduzindo a prestação de serviços de transmissão;

Modelo 4: é o novo modelo britânico. Exige a separação vertical completa da geração, transmissão e distribuição.

A questão central, é até que ponto é desejável que a competição se dê em toda a estrutura da indústria elétrica. Há relativo consenso quanto a potencialidade de competição na geração de eletricidade.

Há também certa aceitação de que a transmissão e a distribuição sejam em muitas circunstâncias, monopólio natural. Portanto, fica caracterizada a questão de onde o serviço deveria continuar sendo fornecido por um monopólio.

A função de distribuição em muitos países é apresentada como monopolista. Isto significa que a empresa de serviço público tem o direito de monopólio quase exclusivo. Diante disso, muitos consumidores não tem acesso a outros fornecedores.

Duas opções podem ser adotadas: o acesso no atacado, permitindo apenas aos geradores e às empresas de serviço de distribuição o acesso a rede de transmissão e o acesso do varejo, o que significa permitir o acesso aos consumidores finais.

O que se observa, na prática é que só os grandes clientes têm se beneficiado, até agora do processo de competição estabelecido na indústria elétrica no mundo inteiro. Eles são chamados de consumidores livres. Os pequenos consumidores continuam vinculados às suas distribuidoras, 
constituindo-se no chamado mercado cativo, segmento que se comporta como um monopólio natural ( BAJAY et al., 1996 a).

Verifica-se, no entanto, uma regulação bastante rigorosa do mercado cativo, com destaques em termos de controle tarifário e fiscalização da qualidade do serviço.

Visando apreender o que de mais significativo ocorreu no mundo, quanto as transformações da indústria elétrica e os processos de regulação, passamos a abordar as experiências de alguns países.

\subsection{A EXPERIÊNCIA DA INGLATERRA}

A indústria elétrica inglêsa foi quase que completamente desverticalizada, acabando com a prática de fixação das tarifas com base nos custos e no lucro permitido. Este critério foi substituído pela formação das tarifas com base no preço vencedor de uma licitação, adotado pelo Brasil conforme a lei federal no. 8987/95 ( BAJAY et al., 1996 a).

Como primeiro estágio da privatização, o monopólio da CEGB - Central Electricity Board na geração foi encerrado em 1989 através do "Ato de Eletricidade", o qual levou a uma nova configuração da indústria elétrica britânica. A geração foi dividida em três novas companhias: National Power, PowerGen e Nuclear Electric ( ATKINSON, 1996).

Uma companhia separada ( National Grid ) foi criada para ser a única responsável pela transmissão. Ela não foi envolvida na compra ou venda de eletricidade. 
A propriedade da National Grid Company fio dada às 12 companhias distribuidoras ( RECs), que substituíram as estatais, com a responsabilidade pela distribuição e suprimento aos consumidores em suas regiões.

O novo sistema britânico criou a possibilidade dos clientes com demanda superior a $1 \mathrm{MW}$ negociarem diretamente com os geradores ou distribuidores os preços da eletricidade, com liberdade de escolha de seu supridor.

Adicionalmente, a partir de 1994 o nível de potência requerido para o acesso ao mercado competitivo diminuiu para $100 \mathrm{~kW}$, permitindo maior liberdade de escolha a um número maior de consumidores. Para 1998, planeja-se que qualquer consumidor, inclusive os residenciais, possa esclher o fornecedor de eletricidade que desejar.

O Office of Electricity Regulation - OFFER é o órgão regulador britânico só controlando a qualidade dos serviços das empresas. A qualidade do produto é supervisionada sem muito rigor e não há nenhum controle de custos (BAJAY et al., 1995).

As distribuidoras (REC) são obrigadas, segundo HENRIQUES (1994), a se reportarem trimestralmente ao OFFER, com respeito às suas performances diante dos padrões estabelecidos sob as cláusulas 39 e 40 do "Ato de Eletricidade", de 1989. Existem dois tipos de padrões, conhecidos como padrões garantidos e padrões genéricos.

Os padrões garantidos estabelecem garantias individuais de qualidade aos clientes e os padrões genéricos estão relacionados as áreas de serviços onde os clientes em geral têm o direito de esperar níveis mínimos predeterminados. 
Os padrões são estabelecidos pelo OFFER anualmente e foram introduzidos em julho de 1994. O OFFER estabelece os padrões com base no conselho de clientes e em pesquisas, junto aos clientes e representações de classe.

- Padrões Garantidos : são em número de dez e descritos qualitativamente a seguir:

1. Tempo para restabelecer em caso de falha no sistema de distribuição (11,4 KV);

2. Tempo para restabelecer no caso de falha no sistema de AT (acima de $11,4 \mathrm{KV}$ );

3. Tempo para avisar sobre desligamento programado;

4. Tempo para solucionar problemas de tensão;

5. Tempo para ligação de novos clientes;

6. Tempo para responder a reclamações sobre o medidor;

7. Tempo para responder a reclamações sobre contas;

8. Tempo para responder a outras reclamações;

9. Manter o dia e hora agendados para leitura, entrevista, etc.;

10. Carta ao cliente notificando que existe crédito por quebra de garantia.

- Padrões Genéricos : embora não exista penalidade financeira pelo não atendimento desses padrões, o Offer tem poderes legais para obrigar as RECs a cumpri-los (inclusive com possibilidade de suspensão da licença). Esse padrões não são números absolutos e sim percentuais de cada atividade, estabelecidos anualmente e variam de empresa para empresa. São definidos e dimensionados segundo pesquisa anual junto aos clientes dessas empresas.

As distribuidoras estão livres para criar todo tipo de serviço junto aos clientes. Os mais comuns existentes são: 
- Serviços nas instalações internas dos clientes, quer sejam em execuções de novas ligações ou inspeções periódicas em ligações existentes.

- Atendimento 24 horas por dia via fax, micro ou telefone (centrais de atendimento)

- Contratos de risco para conservação e/ou gestão de energia onde o cliente paga o serviço com a economia obtida no consumo.

- Projeto civil para novas construções ou reformas, visando à conservação de energia.

- Venda de materiais elétricos e eletrodomésticos (em regime de franchising em algumas empresas)

- Implantação de software de controle de carga da instalação na rede de computadores do cliente.

- Suprimento de gás a parques industriais.

- Formas de pagamentos em períodos e preços diferenciados.

O OFFER, como observado, dá uma ênfase particular à qualidade do serviço aos consumidores, dedicando tratamentos especiais para idosos e deficientes e fornecimentos a áreas remotas e, depende essencialmente de comparações entre as empresas distribuidoras para a sua avaliação do desempenho deste segmento da indústria elétrica. Uma compensação é dada aos consumidores quando de um serviço inadequado.

\subsection{A EXPERIÊNCIA DA NORUEGA}

Uma lei, promulgada em 01/01/91, implantou mudanças na estrutura da indústria elétrica do país, objetivando diminuir as diferenças de tarifas entre as regiões, reduzir as discriminações entre os diversos tipos de consumidores e fomentar uma maior eficiência na produção e na distribuição de eletricidade.

governo dividiu a empresa estatal Starkraft (responsável por $33 \%$ da geração do país), anteriormente integrada verticalmente em uma empresa 
somente de geração e uma empresa de transmissão e criou-se a agência de regulação - Norwegian Water Resources And Energy Administration (Norges Energiverkforbund) -NVE. Os demais segmentos da estrutura industrial, incluindo suas dimensões regionais e municipais, não foram alterados (ROSA et al., 1998).

Apesar das medidas adotadas, a reforma norueguesa não alterou o caráter de propriedade pública dos ativos, compreendendo 90 produtores de energia elétrica, 20 empresas concessionárias regionais e 230 concessionárias locais. A geração de energia elétrica na maioria das 537 usinas operando no país é hidráulica (BAJAY et al.,1996 b).

O órgão regulador NVE tem a responsabilidade de regular o mercado monopolista e supervisionar os segmentos sujeitos a concorrência, visando promover a eficiência econômica de toda a indústria.

A geração e o suprimento ao consumidor final não são regulados, pois são considerados mercados concorrenciais necessitando, apenas, de uma autorização, enquanto que os serviços de transmissão e as redes de distribuição são objeto de concessão. Através das concessões, pode-se controlar a estrutura tarifária, sendo que o Ministério de Energia e Indústria funciona como uma espécie de corte de apelação para as empresas recorrerem das decisões do NVE. Esta instância tem a palavra final no que diz respeito a regulação (ROSA et al., 1998).

Cumpre registrar, que a bibliografia consultada não aborda a regulação referente a qualidade dos serviços prestados, fazendo, no entanto, referências apenas aos aspectos concorrenciais. Neste aspecto, dois fatos são citados como consequência do ambiente competitivo para o mercado cativo: a entrada de novos agentes (traders) e corretores (brokers); e a redução e reestruturação dos preços para os consumidores. 


\subsection{A EXPERIÊNCIA DA AMERICA LATINA}

A experiência da América Latina é demonstrada pelas reformas da indústria elétrica do Chile e da Argentina, as quais adquirem particular importância pelo fato

de terem sido aplicadas nesses países em desenvolvimento, diversas experiências verificadas nos países desenvolvidos (ROSA et al., 1998).

Ainda, segundo os autores, no Chile, a partir de 1982, foram introduzidas diversas modificações em sua indústria elétrica, dentre as quais destacam-se, numa primeira fase, a divisão das empresas Endesa e Chilectra em doze e três, respectivamente; a criação da Comissão Nacional de Energia (CNE), com a responsabilidade pela coordenação dos investimentos das empresas, determinar os valores das tarifas e determinar o planejamento indicativo do sistema; e a criação do Centro de Despacho Econômico de Carga (CDEC), subordinado a CNE.

Numa Segunda etapa, ocorreu a privatização de cada uma das empresas criadas, com a venda pulverizada das ações, com forte participação das administradoras de Fundo de Pensão (AFP).

As reformas objetivaram criar competição na geração com preços livres para consumidores com demanda acima de $2000 \mathrm{~kW}$, sendo que os segmentos de transmisssão e distribuição são considerados cativos, com suas tarifas daministradas pela CNE. A regulação estabelece padrões de desempenho a serem observados pelas distribuidoras, que têm autonomia na realizaçãso de seus investimentos.

A exemplo do Chile, a Argentina inicialmente efetuou um processo de reestruturação setorial, dividindo as empresas federais em diversas unidades de negócios, para, após proceder a privatização. 
Desse processo resultaram três empresas de distribuição, seis empresas de transmissăo e vinte e uma empresas de geração, além das vinte e uma empresas de distribuição de propriedade das províncias e seiscentas minicooperativas municipais já existentes.

Outras medidas merecem destaque, tais como a criação do Mercado Electrico Mayorista (MEM), com o objetivo de criar ambiente competitivo no mercado de energia elétrica; criação de um órgão regulador, independente, denominado Ente Nacional de la Eletricidad (ENRE), com as atribuições de definir as niveis tarifários para o mercado cativo, compreendido por consumidores com demanda inferior a $1 \mathrm{Mwh}$ anual; impedir a concentração do mercado e estimular o fim de preços ineficientes, a partir do fim dos subsídios para os consumidores (ROSA et al., 1998).

\subsection{A EXPERIÊNCIA DOS ESTADOS UNIDOS}

O setor de energia elétrica nos Estados Unidos é uma fusão de mais de 3.200 diversas entidades, incluindo: empresas de serviço público dos investidores (IOU), empresas de serviço público pertencentes ao público, cooperativas de energia, órgãos governamentais, cogeradores e produtores independentes de energia (IEPs) (STALON, 19991).

As empresas de serviço público fornecem energia elétrica a mais de 100 milhões de residências, estabelecimentos comerciais e operações industriais. A tabela I, mostra o número aproximado de cada tipo de empresa de serviço público e a capacidade instalada de geração de cada uma. As informações sobre os cogeradores e IEPs, não estão incluídas na Tabela 4.1. 
Tabela 4.1 - Número de Empresas de Serviço Público de Eletricidade e sua Capacidade Nominal de Geração - 1991

\begin{tabular}{|c|c|c|}
\hline Classe de Proprietário & $\begin{array}{l}\text { No. de Empresas } \\
\text { de Serviço Público }\end{array}$ & $\begin{array}{c}\text { Capacidade } \\
\text { Instalada } \\
\text { GW }\end{array}$ \\
\hline Capital Privado & 262 & $\overline{569,8}$ \\
\hline Federal & 10 & 66,6 \\
\hline Municipais e Estaduais & 2017 & 74,0 \\
\hline Cooperativas & 943 & 29,6 \\
\hline$\overline{\text { TOTAL }}$ & 3.232 & $\overline{740,0}$ \\
\hline
\end{tabular}

- Empresa de Serviço Público do Investidor

As empresas de serviço público do Investidor (IOUs) abrangem o maior segmento do setor de energia elétrica, gerando $78 \%$ da energia elétrica disponivel nos Estados Unidos e atendendo $76 \%$ dos consumidores totais.

Os sistemas pertencentes ao investidor, geralmente recebem franchises territoriais exclusivos dos órgãos regulamentadores governamentais locais ou estaduais. Como sugere a classificação, os investidores da empresa, isto é, compradores de ações, são os proprietários. Devido à natureza especial das franquias de empresa de serviço público de eletricidade, a administração das empresas de serviço público deve ser suscetível as necessidades de seus consumidores. 
- Cooperativas Rurais de Eletricidade

A administração da Eletricidade Rural (REA) foi fundada como um órgão dentro do Ministério da Agricultura em 1935 pelo Ato do Executivo 7037. A Lei de Eletrificação Rural de 1936 autoriza o Administrador da REA a fazer empréstimos para Cooperativas Rurais de Energia Elétrica com a finalidade de financiar a construção e operação das usinas de geração e das linhas de distribuição e transmissão. A maior parte das aproximadamente 1.000 cooperativas rurais de eletricidade tem sistemas de distribuição, mas há cerca de 60 cooperativas que geram e/ou transmitem energia aos membros do seu sistema de distribuição. (G \& T's).

- Sistemas Públicos não Federais

Há mais de 2.000 sistemas públicos não Federais nos Estados Unidos que consistem em autoridades Estaduais, municipais e distritos especiais da empresa de serviço público.

As empresas de serviço público municipais que tem aproximadamente 1.800 sistemas, são a forma mais comum de entidade pública de energia não Federal. Além disso, há autoridades ou distritos que atendem territórios especificamente estaduais.

\section{- $\quad$ Órgãos Federais}

Os órgãos Federais produzem e comercializam aproximadamente $9 \%$ da energia elétrica do país.

Para que possamos entender como funciona o setor elétrico nos Estados Unidos, temos que abordar aspectos históricos, em que as prefeituras foram os primeiros reguladores das empresas de eletricidade e ainda são reguladores 
importantes para muitas empresas públicas e particulares. Ao exercer o poder municipal para exigir que as empresas de serviço público obtenham uma franquia antes de fornecerem serviços em uma cidade, elas continuam exercendo poderes de regulação sobre a localização das linhas de distribuição, estações transformadoras e usinas de geração nas áreas urbanas.

Os governos municipais, em contraste com outras unidades do governo, eram controladores lógicos deste monopólio com franquia por muitos motivos: (1) os pioneiros sistemas de corrente contínua atendiam pequenas áreas, portanto, 0 governo municipal podia exigir representar todos os consumidores, (2) muitos dos primeiros sistemas eram de propriedade dos municípios, e, provavelmente, os mais importantes, (3) todas as empresas de eletricidade, mesmo as particulares, usavam o ativo do município como o espaço aéreo e/ou terrestre sob ou sobre as ruas, calçadas e parques municipais. A legitimidade política da regulamentação municipal foi severamente enfraquecida quando as empresas de serviço público de eletricidade, explorando a física da corrente alternada, cresceram para atender os consumidores rurais e urbanos (STALON,1991).

Nos EUA a regulação das empresas de serviço público de eletricidade é efetuada basicamente pelos governos federais e estaduais e alguma regulamentação a nível local, contudo, esta geralmente toma forma de autorizações de usos especiais. A regulação a nível estadual varia de estado para estado, mas geralmente inclui aprovação de tarifas e a emissão de certificados de necessidade e conveniência para a construção de novas instalações.

\section{a. Regulação Federal}

Nos EUA, a Comissão Federal de Regulamentação de Energia Elétrica (FERC) é o órgão federal basicamente responsável pela regulamentação das empresas de serviço público de eletricidade. A FERC regulamenta as transações interestaduais de uma empresa de serviço público, operações por atacado e 
autorização para construção de uma usina hidroelétrica. A regulamentação do Ministério de Energia (DOE) das empresas de serviço público de eletricidade é limitada à emissão de autorizações (autorizações presidenciais) para a construção de linhas de transmissão de eletricidade internacionais e a autorização de exportações de energia elétrica para um país estrangeiro. O Governo Federal não regulamenta as importações de eletricidade.

\section{- $\quad$ Ministério de Energia}

São necessárias autorizações presidenciais para construir instalações de transmissão de eletricidade através de uma fronteira dos EUA. O Ato do Executivo no. 10485 declara que, antes que a autorização presidencial possa ser emitida, a ação deve ser considerada em conformidade com o interesse público. O DOE estudou a coerência com o "interesse público" para pedir uma constatação de que as instalações propostas não causarão um impacto negativo na confiabilidade técnica do sistema de fornecimento de energia elétrica nos EUA. Consequentemente, a confiabilidade técnica da eletricidade é o critério básico usado para determinar se a autorização deve ou não ser concedida.

A aprovação da Lei de Políticas Ambientais nacionais de 1969 (NEPA) impôs uma exigência em cada órgão federal de que qualquer ação federal mais importante seja tomada apenas após a consideração plena de todas as conseqüências ambientais dessa ação.

- Comissão Federal de Regulação de Energia

Todas as operações interestaduais por atacado (venda ou revenda) das empresas de serviço público estão sujeitas à jurisdição da Comissão Federal de Regulação de Energia, anteriormente à Comissão Federal de Energia (FPC). A Lei Federal de Energia de 1935 concedeu à FPC autoridade para regulamentar as 
vendas interestaduais de energia elétrica. Com a aprovação desta Lei, a FPC e sua sucessora, a FERC, recebeu autoridade sobre:

- A disposição, fusão ou consolidação das instalações e a aquisição de títulos de uma outra empresa de serviço público.

- Emissão de títulos.

- As tarifas de venda no atacado e serviços das empresas sob sua jurisdição.

- Contratos de compra de energia e acordos de interligações.

\section{b. Regulação Estadual}

Todos os estados nos EUA possuem órgãos de regulação (normalmente chamados de Comissões da Empresa de Serviço Público) que exercem graus variados de autoridade sobre as atividades da empresas de serviço público de eletricidade. A maioria das comissões estaduais estabelece tarifas que as empresas podem cobrar dos seus consumidores a varejo, aprovar (ou reprovar) a construção de novos projetos e determinar as condições dos contratos de compra/venda de energia da empresa de serviço público.

Um exemplo dessas comissões, em âmbito estadual, citamos a Comissão das Empresas de Serviço Público da Califórnia (CPUC), que regulamenta as tarifas e a qualidade dos serviços das empresas de eletricidade privadas (IOUs) que operam dentro da Califórnia.

Além da CPUC, a Comissão de Energia da Califórnia (CEC) também exerce jurisdição sobre as operações das empresas de serviço público de eletricidade. A CEC aprova a construção e operação das instalações de geração termoelétrica de $50 \mathrm{MW}$ ou mais, dentro do estado.

A CEC é também o órgão de liderança no estado para a previsão de demanda a longo prazo e planejamento de recursos, desenvolvimento de padrões de conservação de energia, desenvolvimento de novas tecnologias de energia, e 
localização de linhas de transmissão que levam desde instalação de geração propostas até o primeiro ponto de interligação da empresa de serviço público. Como a CPUC, a CEC leva em consideração o interesse público e os impactos ambientais ao examinar um pedido de localização.

Ao examinar os pedidos de localização de instalações ou de moderação de contratos de energia comprada, a CEC e a CPUC realizam seus estudos em fóruns públicos.

Na primeira década do século $X X$, a junção dos reformadores progressistas $\mathrm{e}$ dos lideres do setor elétrico, persuadiram muitos estados a substituir a regulamentação estadual pela municipal das IOUs (empresas particulares). Os governos municipais, logicamente, receberam a autorização, na maioria dos estados, para continuar a controlar as empresas de serviço público municipais em quase todas as dimensões de suas atividades e a continuar a controlar as IOUs nas atividades que afetam diretamente a propriedade municipal. A maioria das dimensões do controle econômico, contudo, foi concedido a um órgão estadual, freqüentemente chamado de Comissão de Empresa de Serviço Público - PUC.

O compromisso pelas partes conflitantes comprovou ser durável e ainda demonstra uma grande força. Os órgãos federais de regulação freqüentemente refletiram o mesmo compromisso, portanto, ele merece explicação. 0 compromisso tem quatro características decisivas:

- A propriedade privada de empresas de serviço público de eletricidade com amplos poderes de monopólio protegida e estimulada pelo governo é aceita como uma organização ou forma desejável quando as economias de escala, podem ser eficientemente exploradas melhor desta forma, do que através de competição de mercado não controlado. 
- O controle total dos preços das empresas de serviço público de eletricidade, qualidade dos serviços e a estrutura financeira são conferidos a um órgão estadual "independente".

- "Independência" significa que o órgão tem vários membros, (geralmente denominados comissários, mas ocasionalmente denominados membros da comissão ou juizes), tem um mandato fixo, razoavelmente longo (de 4 a 6 anos), freqüentemente alternado, de forma a fornecer aos comissários a proteção contra pressões políticas de curto prazo. A independência também significa que o órgão possui um quadro de pessoal com peritos técnicos que são diretamente responsáveis pelas decisões.

- O arbítrio do órgão é limitado, possibilitando que as interpretações constitucionais e da legislação geral:

a) forneçam a cada empresa de serviço público amplas oportunidades para apresentarem provas e argumentos para persuadir o órgão quanto à visão da empresa de serviço, de seu interesse e do interesse do público;

b) exijam que ele permita que a empresa de serviço público, se eficientemente administrada, ganhe uma taxa de retorno "justa e razoável" sobre o ativo voltado aos serviços públicos; e

c) dêem o direito às empresas de serviços públicos de recorrer aos tribunais federais e estaduais para examinar as decisões da PUC.

Este direito tem sido de grande importância para as empresas de serviço público e na prática o controle econômico tem sido uma operação conjunta das PUCs e tribunais.

Em meados da década de 20, a maioria das empresas de serviço público estava operando como monopólios sancionados pelo estado com a obrigação geral de prestar serviço a todos os consumidores em seus territórios a preços aprovados pela PUC. Estas empresas de serviço público eram de responsabilidade das PUCs pela maior parte de suas atividades. Quarenta e nove 
estados atualmente possuem PUCs. Nos últimos estados, Texas e Minnesota, as PUCs foram criadas na década de 70. A única exceção, o estado de Nebraska, não tem quaisquer IOUs para controlar.

A medida que os aperfeiçoamentos nas tecnologias de geração e de transmissão de energia tornaram comuns as transações interestaduais e entre as empresas de serviços públicos, os controladores estaduais tentaram impor controle sobre as vendas das empresas de serviço público aos consumidores em outros estados, e sobre as compras das empresas de serviço público em outros estados. Em 1927, O Supremo Tribunal Americano sustentou que estes controles do estado sobre as transações de venda no atacado interestadual impõe um ônus direto sobre o comércio interestadual, violando a Cláusula Comercial da Constituição Americana. Este aspecto somente foi regulamentado a partir da Lei Federal sobre energia em 1935 (FPA), onde o Congresso concedeu à Comissão Federal de Energia (FPC) predecessora da FERC, autoridade para controlar a "transmissão de energia elétrica no comércio interestadual".

Este esforço para preservar a regulamentação estadual foi reforçado pelo outro componente principal da Lei de 1935. A Lei de Empresas Holding de Serviços Públicos (PUHCA). Antes desta legislação, a eficácia das PUCs estaduais fora depreciada por incorporações horizontais de empresas holding, e pelas incapacidades legais e práticas das PUCs de penetrarem nas estruturas complexas de empresa holding e pelas proibições legais contra o controle estadual das relações entre matrizes.

Em 1978 o Congresso promulgou a PURPA - Lei das Políticas de Regulamentação de Empresas de Serviço Público, cujas principais alterações, segundo STALON (1991), foram as seguintes: 
- Incorporou o interesse do governo federal no projeto de tarifa a varejo, uma área de controle previamente considerada como sendo uma questão totalmente estadual.

- Determina que as empresas de serviço público comprem energia dos cogeradores e dos pequenos produtores que atendam algumas especificações.

O modelo da PURPA, parte da regulamentação tradicional da empresa de serviço público, sendo que ele centraliza o regulamento tarifário sobre a empresa compradora e não sobre a empresa vendedora. Visto que a prudência da PUC examina tipicamente os enfoques nas empresas compradoras, dar aos estados um grande papel no estabelecimento das políticas de aquisição dos compradores, parece intuitivamente racional (STALON, 1991).

As empresas de energia elétrica, portanto, foram obrigadas a comprar energia elétrica dos novos produtores e dos cogeradores a um determinado preço representado pelo custo/kWh da eletricidade ou o custo/kW de capacidade referenciado ao próximo projeto de expansão da geração da concessionária, também chamado de custo evitado da concessionária. Este custo seria determinado pelas PUCs.

De acordo com o PURPA dois tipos de produtores eram qualificados aos benefícios acima citados: os cogeradores e os pequenos produtores que utilizassem como fonte de energia primária, pelo menos $75 \%$ de energia renovável e se subordinassem a certos critérios de propriedade, operação e eficiência, estabelecidos pela FERC. Estes são as chamadas "Qualifying Facilities - QFs" (SANTOS, 1997).

A PUHCA e a FPA foram bem sucedidas ao restabelecer a eficácia das PUCs, que atualmente são uma força regulamentadora poderosa em muitos 
Estados. Seu órgão nacional a Associação Nacional de Comissárioa de Controle das Empresas de Serviço Público (NARUC), é uma força poderosa na moldagem da política nacional.

Três cláusulas da FPA descrevem razoavelmente a divisão de trabalho entre os controladores estaduais e federais a seguir expressas:

a) impõe controle federal sobre a transmissão de energia no comércio interestadual e na venda desta energia no atacado no comércio interestadual. Contudo, conclui que este controle federal (deve) abranger apenas aquelas questões que não estão sujeitas ao controle estadual.

b) declara que os controladores federais "não devem ter jurisdição (com algumas pequenas exceções) sobre as instalações usadas na distribuição local ou (apenas para transmissão da energia elétrica no comércio interestadual), ou sobre as instalações para transmissão de energia elétrica consumida totalmente pelo transmissor.

c) concede à FERC o poder de criar executar normas de contabilidade para as IOUs. Nega à FERC qualquer jurisdição sobre as POUs.

Em resumo, a jurisdição da FERC inclui a fixação de preço da energia vendida pelas IOUs e IEPs para revenda, e fixação de preços de serviços de transmissão interestadual "no varejo" das IOUs. 


\section{A VISÃO EMPRESARIAL DA PARTICIPAÇÃO DO PÚBLICO NA INDÚSTRIA ELÉTRICA AMERICANA: ESTUDOS DE CASO}

\subsection{ESTUDO DE CASO 1: PACIFIC GAS \& ELECTRIC ${ }^{4}$}

A Pacific Gas and Electric Company (PG\&E) é a maior empresa de serviço público de eletricidade e gás dos Estados Unidos da América do Norte, possuída por investidores oficialmente em 1905, traz consigo as características de uma empresa de gás que iniciou em 1852 e de uma empresa de eletricidade de 1879. Seus primeiros líderes eram empresários e financiadores que foram os pioneiros na venda de ações ordinárias para os consumidores, inaugurando o conceito de propriedade do consumidor da empresa de serviço público.

\subsubsection{Antecedentes históricos}

O caso em estudo está relacionado com a PG\&E no final da década de $70 \mathrm{e}$ início da década de 80 quando a empresa atendia aproximadamente 3,5 milhões de consumidores de eletricidade e 3 milhões de consumidores de gás em 48 das 58 regiões da Califórnia. Isto representa a maioria das partes norte e centro daquele estado. Atendia a uma população com uma renda per capita mais alta do que a média nacional. A área da economia é bem diversificada, constituída de pesquisa e fabricação de produtos eletrônicos e aeroespaciais, processamento de alimentos, refinaria de petróleo e agricultura.

Em 1981, diversos eventos combinaram-se para galvanizar a opinião pública em protestos contra as tarifas crescentes. O pano de fundo para os protestos foi uma grande recessão econômica que provou ser difícil, de forma particular, para uma série de setores industriais chaves na área de concessão da PG\&E. Foram especialmente atingidos a habitação, a indústria automobilística e os produtores florestais. Um grande número de trabalhadores foi dispensado. Muitos dos 
desempregados eram consumidores da PG\&E que moravam em casas com energia elétrica, nas áreas das encostas do estado, e portanto, particularmente vulneráveis a qualquer aumento de tarifa.

Ainda no cenário estava uma série de questões não relacionadas com as tarifas que tinham gerado uma quantidade incomum de publicidade desfavorável à empresa. No outono de 1981, a empresa recebeu uma licença da NCR para encher de combustivel e testar a Unidade I da Usina Nuclear de Diablo Canyon.

Ocorre, que um erro de engenharia foi descoberto seis dias depois, levando a suspensão da licença em meados de novembro. $O$ erro que a administração da PG\&E caracterizou no Relatório Anual de 1981, como "uma falha imperdoável por não seguir nossos procedimentos de controle de qualidade bem estabelecidos", tornou-se rapidamente uma causa célebre na mídia local e, inquestionavelmente serviu para destruir a confiança pública na empresa. Outra publicidade negativa incluiu a crítica aos contratos de longo prazo da empresa (iniciados em 1976 durante a estiagem) para comprar petróleo a preços mais altos do que no mercado corrente. Nesse particular, um grupo de consumidores apelou para o Supremo Tribunal do Estado que fez com que os bancos envolvidos, que suportaram aqueles contratos, (que adiantaram recursos), retirassem aqueles recursos até que a apelação fosse resolvida. A apelação também buscava averiguar o que havia de verdade numa série de reportagens apresentada pela televisão, sobre as práticas e precisão de faturamento/leitura de medidores.

Foi neste contexto que a questão da tarifa surgiu no cenário. No último semestre de 1980, a PG\&E tinha preenchido pedidos para um aumento de tarifas geral para 1982, com um aumento tarifário intermediário para 1981, visando cobrir o déficit provocado pelo aumento, concedido à empresa em 1980, e diversos aumentos de reajuste do combustivel.

${ }^{4}$ Relatório do EDISON ELECTRIC INSTITUTE, Vol. 8, 1982. 
Foi concedido à empresa um aumento provisório de tarifa geral em fevereiro de 1981,e logo a seguir, recebeu dois aumentos de reajuste de combustível, um em vigor em junho e outro em outubro.

Em 30 de dezembro de 1981, a CPUC aprovou um reajuste geral de tarifas para a PG\&E, em vigor em primeiro de janeiro de 1982. Como parte de sua decisão, a CPUC inesperadamente pediu que a estrutura tarifaria fosse revisada. O efeito desta mudança estrutural fêz aumentar a conta mensal do grande consumidor de eletricidade sem qualquer aumento nas próprias tarifas. De acordo com a CPUC, a finalidade da revisão foi "mandar sinais de conservação mais corretos aos consumidores".

O efeito conjunto de vários aumentos tarifários aprovados em 1981, juntamente com mudanças na estrutura tarifaria, foi o de aumentar as contas de grandes consumidores de eletricidade em quase $97 \%$ para o mesmo consumo. Além disso, para muitos consumidores que moravam nas encostas das montanhas, janeiro de 1982 foi muito mais frio que 1981, e como conseqüência, muitos desses consumidores tiveram suas contas de janeiro, aproximadamente 200\% mais caras do que as do mesmo período de 1981.

Se muitas contas pareceram "estar saindo pelo telhado", muitos consumidores também. Os protestos começaram no dia em que a CPUC anunciou o aumento geral de tarifa. Os protestos anteriores eram previsiveis a partir dos grupos de consumidores que tinham acompanhado o caso. Eles foram seguidos rapidamente por reclamações de contribuintes individuais. Os escritórios das empresas foram inundados de chamadas telefônicas, consumidores irados e enraivecidos, com recados obscenos nas contas de luz.

O que começou como reclamações individuais tornou-se rapidamente em protestos organizados. Grupos de protestos de consumidores locais e dos arredores foram formados quase da noite para o dia em cerca de 40 a 50 
comunidades. Os protestos tiveram várias formas: piquetes nos escritórios das empresas, encontros na cidade para os quais, os representantes das empresas eram convidados apenas para serem vaiados, repreendidos e insultados, "black outs" voluntários e demonstrações de "desligar a tomada". A certa altura, uma federação livre de grupos de consumidores, denominando-se "A REUNIÃO DA CALIFÓRNIA", apresentou-se na capital do estado apossando-se de uma ampla cobertura de notícias pela televisão e manchetes em todo o estado.

\subsubsection{0 atendimento ao consumidor como estratégia empresarial}

Há muitas razões pelas quais a empresa que está com problemas ( ou que realmente não está com problema) deveria seguir em frente com sua própria força. Então, foi dessa forma que a PG\&E, enfrentou a rebelião dos consumidores de grandes proporções no início de 1982 e chegou ao que a administração e os consumidores perceberam como sendo uma das forças da empresa ATENDIMENTO AO CONSUMIDOR.

É claro que a PG\&E não é a única dentre as empresas de serviço público que dê ênfase sobre $O$ atendimento ao consumidor. $\mathrm{Na}$ verdade, os demonstrativos das missões das empresas de serviço público no país estão repletos de referências ao atendimento ao consumidor e, na maioria dos casos, o atendimento é considerado uma meta empresarial importante. Mas a longa batalha da PG\&E em relação as manifestações públicas emprestou uma urgência especial para garantir um alto nível de atendimento e satisfação do consumidor.

A ética do serviço foi reiterada no primeiro demonstrativo formal das metas empresariais publicadas em dezembro de 1981, um mês antes do tumulto público sobre os aumentos de tarifa ocorridos no cenário. A primeira das nove metas estabelecidas no demonstrativo centralizou-se no serviço: 
"Fornecer o nivel mais elevado de confiabilidade, segurança, energia eficiente e serviços de conservação aos consumidores da empresa, permitido pelas tarifas autorizadas pela Comissão das Empresas de Serviço Público da Califórnia, com ênfase especial no fornecimento de serviço cortês em todas as ocasiōes".

A ênfase da empresa no serviço ao consumidor ao longo dos anos já deixou suas marcas.

As pesquisas do consumidor deram coerentemente boas notas a PG\&E pelo serviço, e mesmo durante o auge do tumulto no início de 1982, os resultados da pesquisa mostraram pouca ou nenhuma deterioração na avaliação do consumidor da qualidade dos serviços da PG\&E. Na verdade, esta expressão positiva contínua das atitudes do consumidor serviu para reafirmar a conviç̧ão da administração que ela "deveria continuar com sua própria força" na tentativa de diminuir e, se possível, alterar a insatisfação do consumidor sobre aumentos tarifário recentes.

A administração na ocasião também tinha o beneficio de vários programas voltados para o consumidor, que foram realizados por vários escritórios regionais no triênio 79/81. Um destes programas envolveu a divisão de Berkeley. Em 1979, os gerentes regionais de Berkeley ficaram preocupados sobre o possivel impacto das tarifas mais elevadas. A preocupação deles originou-se de cinco acontecimentos que tinham ocorrido na área de Berkeley em 1979:

- Uma maioria radical foi eleita para o Conselho da cidade com base em plataformas que foram potencialmente desfavoráveis à empresa;

- Diversos elementos da comunidade demonstraram raiva e atitudes negativas voltadas à empresa;

- Aproximadamente $3 / 4$ dos cargos de gerência da PG\&E de Berkeley foram assumidos por novos titulares; 
- As reclamações do consumidor, particularmente com relação às leituras do medidor, indicaram que existiam problemas importantes de performance entre o pessoal da divisão; e

- Existiu uma incidência maior de dissabores, reviravolta religiosa e absenteísmo entre o pessoal da divisão.

A força tarefa realizou uma ampla análise da área de concessão e concluiu que a conservação de energia oferecia uma área de interesse mútuo para a empresa, seus consumidores de Berkeley e uma área específica para a prestação de serviços adicionais. A força tarefa constatou a este respeito que :

- Os consumidores na área de Berkeley mostraram um nível particularmente elevado de interesse na conservação de energia;

- A empresa estava posicionada para desenvolver uma ampla variedade de serviços tangiveis de conservação voltados às necessidades específicas dos principais segmentos de mercado.

- A comunidade, por meio de sua orientação ativista, estaria receptiva a uma campanha de conservação pró-ativa, altamente visível, feita pela empresa; e

- Os consumidores de Berkeley estavam voltados para à visão de grupo, e assim, as câmaras municipais de comércio e outros grupos comunitários ofereceram apoio para os esforços da empresa.

A força tarefa também examinou as operações internas do escritório de Berkeley e constatou que:

- A performance de leitura do medidor estava realmente ruim afetava negativamente a performance de outras áreas;

- Existiam desequilíbrios de demanda de trabalho entre as diversas áreas;

- Muitos empregados foram treinados inadequadamente para seus cargos;

- Os empregados perceberam que estavam trabalhando em uma área difícil, com consumidores exigentes; 
- Os empregados queriam um retorno de performance específico e maiores informações sobre as operações da empresa;

- Os empregados sentiram que o reconhecimento dos esforços individuais e do grupo era inadequado; e

- Que havia um consenso quase geral de que o escritório estava subdimensionado em seus recursos.

Entre as recomendações específicas oferecidas e implantadas pela força tarefa com relação às operações internas estavam:

- Desenvolvimento de treinamento, programas de auditoria e de assistência especial nas áreas de leitura de medidor;

- Criação de dois cargos adicionais administrativos e um representante temporário para contatos na comunidade, e a redistribuição das cargas de trabalho administrativo;

- Estabelecimento de vários programas de reconhecimento dos empregados envolvendo visitas dos gerentes de distrito e divisionais, almoços e cafés da manhã especiais, programas de prêmios e similares; e

- Esforços de maiores informações como boletins, jornais de empresas, reuniōes gerais e em grupo, distribuição de artigos, oradores externos da empresa.

\subsubsection{Os resultados da PG\&E}

O que impressionou a administração da empresa no início de 1982 foi o impacto aparente do programa de Berkeley sobre as relações empresa/consumidor. Pesquisas relacionadas a reclamações sobre contas de energia recebidas pelo escritório de Berkeley em 1980 diminuíram 26,4\% a partir de 1979 e diminuíram 10,5\% em 1981 (a partir de 1980). Talvez, de forma mais significativa, no auge do protesto no início de 1982 , as reclamações no escritório 
de Berkeley aumentaram apenas $9,5 \%$ comparadas com o aumento de $25 \%$ no restante da área de concessão da PG\&E.

A partir do ocorrido em Berkeley, o que se constatou foi que em todos os casos onde foram feitos esforços especiais para ampliar os serviços ao consumidor a fim de satisfazer as necessidades individuais de diversos segmentos de mercado, o nível dos protestos recebidos durante o inverno de 1981 a 1982 foi mais baixo.

Os administradores da PG\&E incumbidos de desenvolver uma estratégia empresarial para lidar com o protesto público no início de 1982 confiaram muito na experiência obtida com os programas anteriores. Conforme observou um dos membros da administração da empresa, na ocasião:

"Primeiro, nossos serviços são a nossa força: os consumidores detestam nossas tarifas, mas ainda adoram o nosso serviço - ou seja, aqueles que foram atendidos ou ajudados pessoalmente por um de nossos empregados".

"Segundo, a participação visivelmente grande e pró-ativa da comunidade pareceu produzir melhor resultado do que as políticas fechadas da empresa. Esforços extras para se comunicar com os consumidores pareceram contribuir para melhorar a aceitação e a compreensão da empresa ( e nossas tarifas mais elevadas). Saindo do nosso hábito, para estar bem à frente e avisar os consumidores que suas contas iriam aumentar, pareceu a longo prazo resultar em menos reclamaçōes do que voltar e deixar que os consumidores sentissem o impacto total em suas contas".

"Terceiro, nossos empregados, ao lutarem corajosamente para lidar com o grande número de consumidores insatisfeitos, nem sempre foram conscientes como deveriam ter sido sobre os programas e políticas atuais da empresa. Como conseqüência, eles nem sempre estavam aptos a dar as 
melhores respostas às perguntas do consumidor ou oferecer a eles a ampla variedade de assistência que a empresa tinha para oferecer".

"Finalmente, os escritórios e as divisões mencionadas anteriormente mostraram que os escritórios distritais e locais poderiam eficazmente executar sob medida os recursos da empresa para liberar um pacote de serviços que atendiam às necessidades e situações locais. Era bem claro que os escritórios que faziam um planejamento pró-ativo foram mais bem sucedidos do que outros ao atingir todos os departamentos - gás, eletricidade, marketing, conservação, e serviços ao consumidor - na mesma proporção. Mas, esquemas de planejamento e know-how não foram distribuídos igualmente na empresa. Muitos escritórios estavam tão ocupados em não se deixarem atingir - que não tiveram tempo de desenvolver e implantar planos de comunicação de serviço local abrangentes (EEI, 1982) ${ }^{5}$.

A estratégia proposta apresentava dois elementos chaves:

1) Descentralização da autoridade e responsabilidade pelo desenvolvimento dos planos locais às divisões e distritos, deixando que eles decidissem quais serviços deveriam ser enfatizados e promovidos dentro de suas respectivas áreas de concessão; e

2) Desenvolvimento, pelo pessoal da empresa, de programas de inventário, serviços, e outros instrumentos que o pessoal da divisão e distrito poderia esboçar para entregar serviços feitos de acordo com as necessidades individuais de vários segmentos de mercado dentro de seus territórios. A estratégia, neste ponto, não era para acelerar o desenvolvimento de novos programas e serviços, mas para fazer uso total daqueles já existentes. Além do mais, a estratégia permitiu uma ênfase na diversidade local ao invés de

\footnotetext{
${ }^{5}$ Relatório do EDISON ELECTRIC INSTITUTE, 1982 - tradução do autor.
} 
solicitar aderência a uma fórmula geral.

Como um primeiro passo na realização de catalogação de programas relacionados com o serviço, o pessoal da empresa, em meados de 1982, elaborou um manual intitulado "The Tool Kit" (O Conjunto de Ferramentas). O manual foi designado aos representantes divisionais e distritais de serviço ao consumidor e continha uma descrição de todos os programas de conservação e serviço ao consumidor oferecidos pela empresa. Estes incluíam cerca de 35 programas de serviço residenciais, 11 programas de serviços comerciais, e 15 programas educacionais e diversos. O manual foi complementado por uma série de seminários, relatórios e um boletim informativo quinzenal - Hot Line - os quais oferecem respostas às questões do consumidor e empregados.

Mas para alguns, as medidas tomadas não podiam, de forma significativa, ser medida para outros fenômenos no futuro em termos de redução das reclamações do consumidor. Eles argumentavam que a empresa estava passando por uma mudança fundamental em como ela percebia a si mesma e seus consumidores. Eles caracterizavam esta mudança como um movimento da orientação do fornecimento ou produção para uma orientação do marketing $\mathrm{e}$ consumidor, e eles acreditavam que todas as empresas de serviço público, teriam eventualmente que passar por esta mudança. Eles ainda argumentavam que o serviço era a chave para a reorientação.

Assim, a administração da PG\&E definia sua estratégia empresarial:

"Estamos agora comercializando o próprio conceito de serviço - a idéia de que nossa razão de existir é para atender às necessidades do consumidor, para procurar satisfação fornecendo uma variedade de escolhas, e escolhas que irão, acima de tudo, possibilitar a ele exercer mais controle sobre sua conta de luz e gás... Este conceito de comercializar o serviço... está coerente com nossos valores empresariais básicos. Na PG\&E, este compromisso tem suas origens nos 
Velhos Acendedores de Lampião de uma de nossas empresas predecessoras aqui em São Francisco, a San Francisco Gas Co.

Todas as noites sem exceção, os acendedores de lampião pegavam suas tochas, escada e subiam e desciam as ruas de Bar Say Coast, que era aqui ao longo da praia, e acendiam as lâmpadas a gás da rua. A área era ameaçadora com o crime, e comerciantes e cidadãos que obedeciam a lei, contavam com a luz para sua segurança. Nosso pessoal era confiável, fidedigno e consciente sobre a sua responsabilidade perante a comunidade. Desde então, o compromisso de nossos empregados de oferecer serviços de qualidade tem sido a meta principal de nossa empresa, algo que permaneceu constante mesmo que muito tenha mudado no ambiente externo".

\subsection{ESTUdO DE CASO 2: PROPOSTA DE PLANO DE PARTICIPAÇÃo PÚBLICA DO EDISON ELECTRIC INSTITUTE ${ }^{6}$}

A privatização do setor elétrico não se afigura, em si, como uma solução para os problemas de eficiência das concessionárias de energia elétrica. Desenvolvendo-se por longo período como monopólio e sujeito ao estatuto da concessão, o setor elétrico, em muitos países, não vivenciou um mercado concorrencial de energia, razão pela qual não teve, até agora, neste, o veículo indutor de eficiência, presente em outros setores não monopolizados da economia.

Nos Estados Unidos, na década de 70 foram implantados os programas de participação pública, sendo que esta foi uma decisão pragmática, quando era necessário manter o apoio do público numa época de aumento dos custos de energia.

\footnotetext{
${ }^{6}$ Relatório : Public Participation do EDISON ELECTRIC INSTITUTE, 1982
} 
Dessa forma, julgamos oportuno descrever o que é uma participação pública e como ela funciona em uma empresa de serviços públicos.

\subsubsection{A necessidade da participação pública}

As principais razões das empresas de serviço público desenvolverem e manterem os programas efetivos de participação pública são os seguintes:

- Reduzir o atraso e os custos relacionados com o litígio e controvérsia política;

- Manter a credibilidade e apoio público; e

- Desenvolver programas e políticas que são responsáveis pelas preferências e preocupações públicas.

Os custos das instalações de transmissão e geração aumentaram muito quando ocorreram atrasos devido a controvérsia, fiscalização reguladora aumentada ou litígio. Projetos foram interrompidos após terem começado, sem retorno das resoluções judiciais pendentes. Em resposta à preocupação pública, os órgãos reguladores passaram a exigir documentação técnica mais ampla que antes. O litígio ampliado poderá produzir não apenas demora e incerteza, mas a total inviabilização de projetos. $\mathrm{O}$ ambiente regulador e legislativo é afetado pela opinião pública e pode ter impacto inclusive sobre a capacidade de alavancar capital.

Há também custos menos tangíveis que são, não obstante, reais. Em uma democracia, o poder origina-se basicamente do "consentimento dos governados". Sempre que as empresas de serviço público são vistas pelo público em geral como não atendendo de forma eficaz o interesse público, são levantadas questões sobre a licença que foi concedida à empresa de serviço público, algumas vezes na forma de demandas judiciais. 
Os aumentos bruscos nas tarifas de eletricidade levaram muitos indivíduos e grupos a questionar com que eficácia as empresas estão atendendo o interesse público. Os resultados foram medidas cada vez mais legislativas que podem afetar a maneira das empresas de serviço público operarem. Em uma época de custos de energia crescentes, em que a incerteza sobre a demanda e a controvérsia social/ambiental continua, a boa vontade do público é essencial para o setor da empresa de serviço público.

A participação pública tenta reduzir os custos da tomada de decisão e restabelece a credibilidade respondendo às necessidades e preocupações públicas antes das decisões serem tomadas. A melhor maneira possível de atingir a tal objetivo, seria chegando ao consenso em cada decisão. Na realidade, contudo, isto nem sempre é possível. Em alguns casos, a divisão entre diversos grupos de interesse pode ser tão severa que é impossível responder a alguns grupos sem desagradar outros. As limitações financeiras, legais, ou técnicas podem excluir algumas soluções que poderiam ser aceitas pelo público. Contudo, mesmo quando não for possível um consenso, é ainda possivel reduzir os custos e atrasos identificando os problemas, reconhecendo as preocupações que exigem estudos técnicos adicionais, sendo sensível aos valores expressos por diferentes grupos de interesse, e minimizando os impactos vistos pelo público como negativos. A participação pública precoce pode também reduzir a pressão para procedimentos reguladores protelados, se as questões forem abordadas de forma eficaz antes de serem levadas a um órgão regulador.

Embora seja raramente possivel a uma empresa de serviço público tomar decisões que satisfaçam todas as pessoas, a maneira pela qual uma decisão é tomada, é sempre importante. Durante períodos de intensa controvérsia política, a maneira de uma empresa atingir e manter a legitimidade é se engajar em um processo de tomada de decisão que seja visível e de confiança do público. Quando isto acontece, as pessoas que se opõem a uma decisão particular irão pelo menos reconhecer que a maneira em que a decisão foi tomada foi justa e 
aberta. Isto pode não ser suficiente para satisfazer os grupos adversários, mas preserva a legitimidade da empresa com o público em geral, e tem um efeito cumulativo ao conquistar a credibilidade dos grupos que freqüentemente se opõem às medidas da empresa.

\subsubsection{As metas da participação pública}

Um programa eficaz de participação pública é projetado para atender as cinco metas a seguir:

a. coleta de informações

Indivíduos e grupos que freqüentemente possuem importantes informações que a empresa de serviço público precisa para tomar uma decisão sábia. Isto pode incluir normas de consumo de energia; efeitos econômicos, sociais e ambientais das medidas alternativas propostas: ou planos a longo prazo de comunidades ou entidades governamentais que afetam a demanda futura.

b. Identificação dos valores e preocupações públicas

Além das informações concretas que o público pode fornecer às empresas de serviço público, se as decisões da empresa atenderem ao público, elas devem ser baseadas em uma compreensão mais completa possível das preferências, preocupações e valores públicos. Visto que diversos indivíduos e grupos de interesse têm diferentes pontos de vista, eles vão avaliar as medidas propostas a partir de diferentes perspectivas. A participação pública fornece um mecanismo pelo qual as empresas de serviço públicos podem compreender problemas, questões, e possíveis soluções a partir das perspectivas dos indivíduos e grupos interessados. 
c. Informações ao público

Para que o público participe de forma eficaz, as pessoas precisam ter acesso às informações confiáveis sobre a natureza dos problemas que estão sendo abordados e das alternativas que estão sendo consideradas.

Também, por serem algumas decisões da empresa muito complexas e técnicas, pode também haver uma necessidade de fornecer informações ao público sobre como as empresas operam e sobre as restrições técnicas, reguladoras e econômicas que as afetam. Deve-se observar que existe diferença entre fornecer informações às pessoas e tentar persuadilas do ponto de vista da empresa.

d. desenvolvimento de um consenso

Visto que o público mantém pontos de vista muito divergentes, nenhuma filosofia de participação pública pode dirigir todas as ações de uma empresa, e deve-se chegar a um consenso em base questão por questão. Ao fornecer uma oportunidade de diálogo entre os diversos grupos de interesse, a participação do público pode promover, de forma eficaz, um consenso sobre os planos propostos da empresa e resultar em um acordo sobre os cursos da ação que são aceitáveis para todos os interesses envolvidos.

e. Desenvolvimento e manutenção da credibilidade

Ao criar um processo de tomada de decisão visível e aberto ao qual todos os interesses têm acesso igual, a participação pública fornece um meio de tornar o processo de tomada de decisão confiável aos grupos com pontos de vista muito diferentes, mesmo quando eles não concordam com a própria decisão. 


\subsubsection{Tipos de participação pública}

Os métodos de participação pública estão evoluindo rapidamente. Destacamos três tipos geralmente utilizados pela maioria das empresas nos EUA.

a) Participação Reguladora

As oportunidades do público de comentar e testemunhar as medidas ou políticas propostas, são feitas na maioria dos processos regulamentadores da empresa de serviço público. Historicamente a audiência pública foi o principal veículo para receber comentários públicos. No entanto, a audiência pública recebeu críticas nos seguintes pontos:

- Os consumidores não são capazes de operar em condições de igualdade com as empresas de serviço público nas audiências, porque eles não têm o mesmo acesso aos dados financeiros e técnicos e também não têm recursos (para viajar, acomodações, etc.), que possibilitariam que eles participassem plenamente;

- As audiências públicas reguladoras chegam muito tarde no processo de tomada de decisão, depois que a empresa de serviço público já está "fechada" em uma alternativa simples ou propôs um método de ação.

Embora as comissões reguladoras tenham sido originalmente estabelecidas para representar os consumidores, as preocupações sobre as "condições iguais" dos consumidores com as empresas de serviço público levaram mais de 30 estados a indicar um "conselho do consumidor" cujo trabalho é representar os interesses do consumidor perante a comissão reguladora. O conselho do consumidor é também capaz de solicitar divulgação total das informações técnicas e financeiras em áreas de controvérsia. Tipicamente, o conselho do consumidor é estabelecido para operar independentemente da comissão reguladora, e está localizado no escritório do procurador geral do estado ou dentro do escritório de 
um órgão de proteção ao consumidor. Normalmente, os recursos são fornecidos através do estado, embora tais recursos também possam ser derivados a partir da avaliação de uma empresa de serviço público.

Um exemplo de programa para representação pública no processo regulador pode ser citado o do Citizen Utility Board (CUB) do estado do Winsconsin. O CUB foi estabelecido por lei estadual para representar os interesses do consumidor perante a comissão reguladora estadual. Quatro vezes por ano, solicita-se que as empresas de serviços públicos dentro do estado, que anexem um pedido de associação ao CUB em seus envelopes do faturamento. Os diretores da CUB são eleitos pelos associados que recebem boletim informativo periódico que os esclarecem sobre os tópicos em estudo pela comissão reguladora e os informa sobre as posições que estão sendo tomadas pelo CUB.

A resposta mais eficaz pelas empresas de serviço público às críticas de que as audiências reguladoras chegaram muito tarde no processo de tomada de decisão foi desenvolver programas de participação pública que incluem o público na tomada de decisão bem antes que quaisquer audiências sejam realizadas.

b) Continuação do diálogo

Diversas empresas de serviço público estabeleceram programas através dos quais é mantido um diálogo contínuo com o público. Nestes casos, os programas não se centralizam nas decisões dos indivíduos, mas são projetados para garantir que a administração compreenda as preocupações e valores dos grupos que freqüentemente questionam as decisões da empresa de serviço público. No passado, as empresas mantiveram contatos formais e informais com os principais consumidores, ficando dessa forma completamente familiarizadas com as necessidades destes consumidores. Contudo, as redes informais que trabalharam de forma eficaz para grandes consumidores não atingiram os grupos mais novos de ambientalistas e consumidores que surgiram na década de 70. Como 
conseqüência foram desenvolvidos novos mecanismos de comunicação com os simpatizantes tradicionais da empresa e com os grupos mais novos. Alguns destes mecanismos são:

- Grupos de consultaria

A técnica mais freqüente empregada para manter um diálogo com o público foi aquela dos grupos de consultoria do cidadão. Em meados da década de 70 diversas empresas de serviço público fixaram grupos de consultoria. Estes grupos normalmente representam uma ampla variedade de interesses, e é solicitado a eles que façam recomendações sobre os problemas da empresa de serviço público a partir da orientação de um consumidor. Muitos foram formados para abordar questões processuais e de serviço relacionadas ao consumidor. Outros estão envolvidos com preocupações políticas e sociais mais amplas como estruturas tarifárias, previsão de carga e opções de capacidade, contratação e emprego, questões ambientais e de segurança e problemas relacionados à energia de cidadãos de baixa renda e mais velhos. Ainda outros grupos são projetados para manter os altos funcionários diretamente informados sobre as preocupações de vários grupos de interesse e de consumidores pelo amplo espectro das atividades da empresa.

- Conferência do diálogo

O Edson Electric Institute patrocinou diversos fóruns projetados para estimular o diálogo entre os líderes do setor da empresa de serviços público e os líderes dos grupos de consumidores e ambientalistas. $O$ atendimento neste fóruns é cuidadosamente equilibrado para garantir representação igual do valor e dos grupos interessados e o formato é projetado para dar a todos uma oportunidade plena de serem ouvidos. Os representantes do setor da empresa de serviço público e de diversos segmentos do público concordam que estes esforços foram 
bem sucedidos na abertura de comunicações e tiveram à cooperação aumentada entre os grupos.

\section{- Relatórios trimestrais}

Diversas empresas começaram a elaborar relatórios periódicos onde elas descrevem as principais questões que surgem e as decisões atuais para líderes de grupos de usuários, consumidor e ambientalistas. A finalidade destes relatórios é dar uma visão geral das operações da empresa, fornecer um fundamento lógico para as decisões recentes, informar os grupos sobre as questões que surgem e ouvir os grupos sobre suas preocupações e as questões que eles acreditam que as empresas estão abordando.

c) Participação nas decisões ou projetos individuais

Muitas empresas implantaram programas de participação pública relacionados a projetos ou decisões específicos. Na maioria dos casos, estes programas são projetados para começar bem antes do processo formal regulador ou de permissão, de modo que a empresa leva em conta as preocupações públicas quando planeja suas ações. Exemplos de tais programas incluem o seguinte:

\section{- Localização das Instalações de Transmissão ou Geração}

Diversos programas de participação pública patrocinados pelas empresas de serviço público envolveram a localização das instalações de geração ou transmissão. Estes programas se focalizaram em todas as etapas do processo de localização, incluindo previsão de carga e opções de capacidade, avaliação dos locais alternativos; avaliação do impacto de desenvolvimento nas comunidades locais; mitigação dos efeitos de um influxo dos trabalhadores de construção, redução de barulho, problemas de segurança ou tráfego relacionados à 
construção; obtenção de acordos com entidades locais ou estaduais, para apresentação às comissões reguladoras a revisão das condições de licenciamento.

É claro que os programas de participação pública como estes, são freqüentemente eficazes na diminuição de atrasos e custos relacionados com controvérsia política adversa e litigação. É também provável que os órgãos reguladores vão começar a estabelecer exigências para participação pública antes do processo regulador formal. Os órgãos reguladores freqüentemente sentem que eles assumem a "questão" política quando as empresas de serviço público não fizeram um serviço adequado da participação pública nas primeiras etapas do planejamento ou formulação do projeto. Por causa disso, é provável que no futuro os órgãos reguladores irão insistir para que os esforços bem intencionados na participação pública sejam um pré-requisito na avaliação das empresas.

\subsubsection{Outras práticas propostas}

a) Planejamento estratégico de longo prazo

Tradicionalmente, o planejamento estratégico ou de longo prazo foi reservado para departamentos de planejamento das empresas ou para a alta administração. Em muitas empresas, uma imagem voltada ao crescimento do futuro se desenvolveu durante as décadas de 50 e 60 e tornou-se quase uma versão "oficial" do futuro, com todo o planejamento da empresa voltado para satisfazer estas demandas de crescimento. Contudo, projetar os padrões futuros de crescimento e decidir como responder aos acontecimentos relacionados às questões de crescimento não são apenas atividades técnicas, mas freqüentemente envolvem muitas hipóteses políticas sobre como "deve" ser o futuro. Há portanto uma necessidade de obter a participação de indivíduos e 
grupos que estão preocupados com a visão do futuro no qual o planejamento da empresa está baseado.

A experiência mostrou que é muito difícil obter a participação do "homem na rua" nas questões que envolvem planejamento de longo prazo. Por esta razão, a participação pública nessas áreas é freqüentemente limitada a um grupo de elite de líderes ou de representantes de interesses organizados, utilizando grupos de consultoria como o principal mecanismo para participação. Como exemplo, citamos uma empresa de serviço público, denominada Puget Soud Power \& Light Company, a qual envolveu mais de 750 cidadãos em estudo de cinco meses da "Estratégia de Energia da Empresa para a década de 80". O público foi convidado a participar de um seminário de um dia e aqueles que demonstraram interesse contínuo foram nomeados para 13 conselhos com a finalidade de estudar os planos da empresa. O programa teve um sucesso tão grande que os grupos de consultoria foram estabelecidos para cada uma das cinco divisões operacionais da empresa.

b) Avaliação das políticas e estruturas tarifárias

Visto que muitas empresas de serviço público tiveram e ainda terão que enfrentar aumentos nas tarifas, a política e a estrutura tarifária se tornaram um tópico extremamente controverso. Diferente de outras questões, que são principalmente de preocupação dos interesses organizados, as tarifas são de interesse do público em geral, uma vez que afeta a todos.

A complexidade das questões sobre tarifa pode apresentar problemas na realização de programas de participação pública. Por esta razão, as principais técnicas de participação pública usadas para este tipo de problema foram geralmente aquelas dos grupos de consultoria ou forças tarefas. Estas técnicas fornecem a continuidade que os participantes precisam para se familiarizarem com as complexidades das estruturas tarifárias e para sugerir alternativas razoáveis. 
Muitas preocupações expressas pelo público - como a distribuição relativa dos custos entre os consumidores residenciais e industriais - exigem que as empresas de serviço público considerem as preocupações sociais que vão bem além dos critérios estritamente econômicos. Trabalhar com o público nestas questões requer uma abertura por parte das empresas para lidar com algumas questões que não consideraram no passado a responsabilidade das empresas de serviço público.

c) Práticas de emprego

Os métodos de participação pública também foram usados no emprego ou contratação de minorias, contratação e promoção de mulheres. Estas são áreas onde a credibilidade da empresa pode ser substancialmente aumentada oferecendo aos grupos interessados nestas questões a oportunidade de estudar os programas da empresa.

Uma outra questão de "empregos" que surgiu durante os programas de participação pública é a questão dos contratos de "primeira fonte" ou outros tipos de compromissos para admitir mão-de-obra local como um meio de mitigar os impactos de um influxo de trabalhadores de construção, ou como um meio de garantia que a comunidade local receba uma participação justa dos benefícios de um projeto. Estes tipos de contratos freqüentemente exigem consulta mais profunda com os sindicatos de trabalhadores, que podem vê-los como uma ameaça a seus membros.

d) Questões ambientais e de segurança pública

Claramente, entre os projetos de participação pública mais controversos para o futuro próximo estarão aqueles que envolverem questões ambientais e de segurança. Nestas duas áreas, o público observa preocupações significativas e exigirá oportunidades plenas para ser ouvido. A ampla variedade de técnicas de 
participação pública deve ser empregada para responder às preocupações do público e para manter a viabilidade econômica do setor.

e) Questões de serviço ao consumidor

Muitas empresas constataram que a participação pública é eficaz ao abordarem as questões de serviços ao consumidor. Há questões que já receberam muita atenção de grupos organizados de consumidores e resolvê-los irá necessitar de diálogo entre diversos interesses. Estas discussões podem também envolver o papel da empresa de serviço público para atingir as metas sociais ao invés de somente entregar energia. 


\section{EVOLUÇÃO RECENTE DA REGULAÇÃO DA INDÚSTRIA DE ENERGIA ELÉTRICA NO BRASIL}

As principais mudanças na legislação sobre o setor elétrico mais recentemente, começaram a ocorrer durante o governo Collor e culminaram com a Lei 9427 de 12/96, e são as seguintes:

- Lei 8631 e Decreto 774 - Março de 1993

Primeiro importante passo para a restruturação do setor, estabeleceu a desequalização tarifária, a extinção da remuneração garantida, o acerto de contas com a CRC, a obrigatoriedade de contratos de suprimento, a reativação da RGR e a criação da CCC - Conta Nacional de Combustíveis, da Política de Conservação de Energia e do Conselho de Consumidores.

- Decreto 915 - Setembro de 1993

Permite a formação de consórcios entre concessionários e auto-produtores para exploração de aproveitamentos hidrelétricos.

- Decreto 1009 - Dezembro de 1993 e Portaria 337 de Abril de 1994 Cria o Sintrel - Sistema Nacional de Transmissão de Energia Elétrica; permite o livre acesso à malha federal de transmissão; incentiva a competição no segmento de geração; define os conceitos e requisitos básicos a serem utilizados e define as condições de comercialização e contabilização.

- Lei 8987 - Fevereiro de 1995

Regulamenta $\circ$ Artigo 175 da Constituição Federal; obriga a licitação das concessões de geração, transmissão e distribuição; e define os critérios gerais a serem aplicados nas licitações e nos contratos de concessão.

- Decreto 1503 - Maio de 1995 
Inclui o sistema Eletrobrás no PND - Programa Nacional de Desestatização e orienta a privatização dos segmentos de geração e distribuição do sistema Eletrobrás.

- Lei 9074 - Julho de 1995

Complementa a Lei 8987, no que diz respeito aos serviços de energia elétrica; cria a figura do produtor independente de energia elétrica; libera grandes consumidores do monopólio comercial das concessionárias; assegura livre acesso aos sistemas de transmissão e distribuição.

- Decreto 1717 - Novembro de 1995

Estabelece normas para prorrogação de concessões de serviços públicos de energia.

- Decreto 2003 - Setembro de 1996

Regulamenta a produção de energia elétrica por produtor independente e autoprodutor.

- Lei 9427- Dezembro de 1996

Institui a ANEEL - Agência Nacional de Energia Elétrica, disciplina o regime de concessões de serviços públicos de energia elétrica.

- Lei Complementar no. 833, de 17 de Outubro de 1997

Cria a autarquia Comissão de Serviços Públicos de Energia - CSPE.

- Portaria no. 349 de 28 de Novembro de 1997

Aprova o Regimento Interno da Agência Nacional de Energia Elétrica ANEEL.

- Decreto Estadual no. 43036 de 14 de Abril de 1998 
Aprova o regulamento da Comissão de Serviços Públicos de Energia CSPE.

- $\quad$ Lei 9648 - Maio de 1998

Autoriza o Poder Executivo a promover a reestruturação da Centrais Elétricas Brasileiras e de suas subsidiárias e dá outras providências quanto ao regime de concessão e permissão da prestação de serviço público, alterando a lei 8987, de Fevereiro de 1995. Altera, também, a Lei 9074 de Julho de 1995, que trata das prorrogações das cocessões e permissões dos serviços públicos. As atribuições da ANEEL, definidadas pela Lei 9427, de Dezembro de 1996, também foram objetos de modificação.

\subsection{O RELATÓRIO COOPERS \& LYBRAND ${ }^{7}$}

Com base na nova legislação, o Ministério da Minas e Energia , encomendou ao consórcio de consultorias, encabeçado pela Coopers \& Lybrand, um relatório do Projeto de Reestruturação do Setor Elétrico Brasileiro, que foi concluído em junho de 1997.

O relatório da consultoria procurou definir o maior número possível de aspectos legais, estruturais, comerciais, jurídicos, regulamentares e institucionais, de modo a implementar a efetiva competição na indústria de energia elétrica, notadamente nos extremos da geração e consumo. Todas as recomendações contidas no documento estão voltadas à estruturação de um novo modelo mercantil, cuja eficácia, segundo os consultores depende de:

- Total neutralidade em planejamento operacional, programação e despacho, atividades que devem ser realizadas de acordo com procedimentos acordados; 
- Política de livre acesso de todos os agentes do mercado ao sistema de transmissão, o que segundo o relatório, exige a segregação vertical de geração e transmissão;

- A existência de um número adequado de geradores e empresas de distribuição e de comercialização de energia (varejo), de portes semelhantes, para estabelecer um mercado atacadista competitivo, sem cartéis ou participações dominantes;

- A separação limitada da geração nas empresas hoje verticalmente integradas, para garantir o acesso ao mercado por parte de outras empresas; e

- A separação das funções de operação e desenvolvimento da rede de distribuição, de um lado, e da comercialização de energia, de outro, nas empresas de distribuição, para possibilitar o desenvolvimento da concorrência no varejo numa etapa futura.

Todas as empresas hoje integradas seriam, dessa forma, obrigadas a separar em empresas distintas suas atividades de geração e transmissão, e, no mínimo contabilmente, as funções de distribuição e de comercialização de energia (que a proposta chama de "varejo"). Como se percebe, tanto a segregação da transmissão com relação à geração, quanto a da distribuição em relação varejo, visam claramente os encargos pelo uso das redes.

Assim, o relatório propõe, em linhas gerais, a seguinte divisão das atividades, que seria reconhecida por regulamentação:

\footnotetext{
${ }^{7}$ Informações extraídas do Projeto de Reestruturação do Setor Elétrico Relatório Brasileiro. Vol. 1 - Sumário Executivo. Rio de Janeiro, Junho de 1997.
} 
- Geração - hídrica, térmica ou a partir de qualquer fonte, incluindo autoprodução e co-geração, a geração seria realizada por companhias de geração (GENCOS);

- Transmissão - transporte em grosso em níveis de tensão de $230 \mathrm{KV}$ ou superiores, dos geradores para os sistemas de distribuição de tensão inferior, realizadas por companhias de transmissão (TRANSCOS);

- Distribuição - transporte local de eletricidade em redes com tensão inferior a $230 \mathrm{KV}$ ( incluindo o que se chama de subtransmissão), desde o ponto de saída do sistema de transmissão até os consumidores finais, realizado por empresas de distribuição (D);

- Varejo - compra no atacado, tanto de energia quanto de serviços de transmissão e distribuição, e sua revenda aos consumidores finais, incluindo as atividades correlatas de faturamento, cobrança e gerenciamento de reclamações, realizadas por empresas de varejo (V).

\subsubsection{O Mercado Atacadista de Energia}

No que tange às transações com energia para garantir a competição, o atual sistema de preços regulamentados de geração e contratos renováveis de suprimento será substituído por um sistema completamente diferente, chamado de MERCADO ATACADISTA DE ENERGIA (MAE), que é a base do novo modelo mercantil proposto pela consultoria.

A entidade principal do MAE será o OPERADOR NACIONAL DO SISTEMA (ONS), administrado conjuntamente pelos agentes, sob a supervisão do Ministério de Minas e Energia e regulamentação da Aneel. Entidade sem fins lucrativo, o ONS será responsável, entre outras coisas, pela rede de transmissão. Suas funções abrangerão o planejamento operacional da geração e transmissão em 
horizontes de até cinco anos; a programação e despacho da geração; cobrança de encargos pelo uso da rede e remuneração dos prestadores dos serviços de transmissão; planejamento do investimento em transmissão em horizonte de tempo de até cinco anos; assegurar novos investimentos em transmissão; e a contabilização e liquidação de energia em nome do MAE.

\subsubsection{Distribuição e varejo}

A desverticalização das funções de distribuição e varejo em todas as empresas de $\mathrm{D} N$ (exceto as de pequenos sistemas isolados), por meio de separação contábil, virá complementar a proposta de criação formal de subsidiárias para deter os ativos de geração e transmissão. A contabilidade separada mostrará claramente o encargo pelo uso das redes de distribuição, permitindo identificar uma tarifa que será aplicada também a transações com varejistas concorrentes de outras empresas e, assim, garantindo acesso á rede em igualdade de condições para todas as partes.

Mas, fora isso, o relatório não propõe ações imediatas de divisão das empresas de distribuição/varejo, dado que já existem hoje um grande número delas e que outras deverão ser criadas com a divisão das empresas estaduais de São Paulo e do Rio Grande do Sul. Recomenda, porém, que nos Estados com maior número de consumidores, em que uma empresa de $\mathrm{D} N$ possa, com o tempo, se tornar dominante, sejam mantidas duas ou três concessões juridicamente distintas, ou seja, uma empresa seria responsável por todas as concessões a curto prazo, mas haveria possibilidade de divisão posterior, caso venha a ser necessário.

Embora desde junho de 1995 (Lei 9074) o Brasil já disponha de legislação sobre o livre acesso aos sistemas elétricos, na prática ele nunca aconteceu. $\mathrm{Na}$ visão dos consultores, tão importante quanto "permitir" o livre acesso é estabelecer tarifas pelo uso das redes de transmissão e distribuição (monopólios 
naturais) que dêem sinais econômicos apropriados e proporcionem retornos razoáveis, e não excessivos, sobre o investimento.

Além disso, para garantir de fato o livre acesso às redes, não basta que se tenham os encargos publicados, mas é também necessário que existam regras claras e transparentes para aprovação de novas conexões. Por esse motivo, o relatório estabelece procedimentos e modelos de documentos que reconhecem os interesses das diferentes partes e esclarecem quem é o responsável em cada estágio.

A definição de transmissão e distribuição é baseada no nível de tensão e não no papel exercido. Assim, para fins de formulação e regulamentação tarifárias, propõe-se que todos os ativos em $230 \mathrm{KV}$ e acima sejam tratados como de transmissão e os inferiores a esta tensão, como de distribuição. Essa definição também será utilizada para fixar o ponto de entrega de eletricidade ao (ou de retirada de eletricidade do) mercado de atacado (MAE), bem como para identificar os ativos de rede sobre os quais o operador independente do sistema teria controle operacional direto (apesar do ONS também ter responsabilidade sobre a programação e despacho de usinas acima de $50 \mathrm{MW}$ conectadas à distribuição) e estabeleceria e administraria encargos de transmissão. Por fim, a definição viria também substituir a de "rede básica" atual, determinando os ativos aos quais seria garantido acesso sobre encargos fixados pela ANEEL.

\subsubsection{Encargos da Distribuição}

Diferentemente de para a transmissão, em que se prevêem encargos diferenciados quanto à localização da conexão ao sistema, a metodologia proposta para os encargos de acesso às redes de distribuição é definida pelas relatividades de preço entre níveis de tensão. A abordagem básica para a derivação de encargos de uso do sistema para cada nível de tensão deve ser a de atribuição de custo incremental de longo prazo, com base em um modelo de rede 
projetado para refletir as características do sistema de cada concessionária de distribuição.

Pela proposta, os encargos devem ser publicados e aplicados ao uso do sistema em períodos de sobrecarga máxima, além de ajustados para recuperar a receita permitida, dada por fórmulas de controle de preços. Ademais, só pagará encargos a carga conectada à distribuição (e não a geração), e os encargos seriam aplicados de maneira idêntica a todos os varejistas, inclusive à área de varejo da empresa de DN possuidora da rede em questão. Os varejistas concorrentes que desejassem utilizar a rede de distribuição firmarão um Contrato de Uso do Sistema de Distribuição.

\subsection{A AGENCIA NACIONAL DE ENERGIA ELÉTRICA - ANEEL}

A ANEEL, uma autarquia criada com a finalidade principal de regular e fiscalizar a produção, transmissão, distribuição e comercialização de energia elétrica, tem a missão de zelar pela qualidade desse serviço, fixar tarifas, estimular a concorrência entre as concessionárias, podendo, para atingir seus objetivos, punir as empresas que não cumprirem o contrato de concessão e não estiverem em linha com as normas e a legislação em vigor.

Com o processo de Reestruturação do Setor Elétrico, a Agência tem um papel fundamental na evolução dos direitos dos consumidores, quando passa a exercer de forma independente o poder regulador e de fiscalização. Apesar de vinculada ao MME, ela tem autonomia financeira e administrativa. Seus diretores têm mandato e não são subordinados ao Ministro ou ao Presidente. As decisões são tomadas de forma colegiada e suas deliberações são públicas.

Deve-se destacar o papel da ANEEL, quanto à regulamentação técnica e de atendimento aos consumidores a seguir discriminado: 
- $\quad$ estabelecer padrões nacionais nas situações em que haja necessidade de uniformidade nos sistemas;

- $\quad$ estabelecer padrões mínimos nas situações onde as Comissões Estaduais possam estabelecer padrões específicos;

- a fiscalização, sempre que possível, com resultados mensurados;

- $\quad$ serão instituídas penalizações financeiras pelo não atendimento de padrões específicos de consumidores;

- as penalidades serão devidas aos consumidores afetados;

- penalizações pela inobservância de padrões genéricos (médias) serão incluídas nas fórmulas de regulação;

- haverá regulação técnica de procedimentos de rede que interfiram no planejamento e operação do sistema principal de geração, transmissão e distribuição, tais como: exigências para conexão à transmissão, critérios de desligamento para manutenção, critérios para planejamento, operação e despacho;

- haverá regulamentação técnica dos procedimentos de competição no varejo, como por exemplo, os relacionados com a transferência de um consumidor livre de um varejista para outro.

Com independência financeira para tomada de decisões e a segurança de pleno e integral exercício do mandato de seus dirigentes, a ANEEL está provida dos recursos necessários para responder às necessidades de um mercado, que com o programa de privatização já realizado, passa a ser atendido em maior parte por empresas de serviço público controladas pelo capital privado.

Um dos diretores da autarquia tem a incumbência de, na qualidade de ouvidor, receber, apurar e solucionar as reclamações, e coordenar as ações de proteção e defesa dos consumidores de energia elétrica, conforme estabelece com clareza o Art. 17 do Regimento Interno da Agência, aprovado pela Portaria $\mathrm{n}^{\circ}$ 349, de 28.11.97. 
Outro ponto de grande interesse ao consumidor é o Art. 20 da Lei $n^{\circ} 9.427$, estabelecendo que "a execução das atividades complementares de regulação, controle e fiscalização dos serviços e instituições de energia elétrica poderá ser descentralizada pela União para os Estados e Distrito Federal, mediante convênio de cooperação", o que pode garantir maior agilidade no atendimento da demanda e qualidade do serviço adequada às características de cada região.

\subsection{A COMISSÃO DE SERVIÇOS PÚBLICOS DE ENERGIA - CSPE: AS PERSPECTIVAS REGULATÓRIAS NO ESTADO DE SÃO PAULO}

As privatizações no setor elétrico, começaram efetivamente em 1995, com a venda da Excelsa no estado do Espirito Santo, da CERJ e da LIGHT no estado do Rio de Janeiro, e até Agosto de 1998 as privatizações já atigiram 14 empresas distribuidoras, e a concessão para a construção de 01 hidroelétrica, conforme demonstrado no ANEXO I. Este resultado, para o Estado de São Paulo significa dizer que grande parte da distribuição de energia elétrica está nas mãos da iniciativa privada.

Como podemos observar, algumas das principais empresas de distribuição do Brasil, já estão privatizadas. Isto significa que dos 35,3 milhões de consumidores residenciais existentes no Brasil em dezembro de 1997, cerca de $60 \%$ foram diretamente envolvidos no processo de privatização, perfazendo um total de 21,3 milhões de consumidores.

A reestruturação da indústria elétrica paulista busca criar as condições necessárias para compatibilizar a imprescindível participação de capitais privados nos negócios de energia elétrica, com a recuperação da capacidade reguladora e fiscalizadora do Estado.

No Estado de São Paulo a Comissão de Serviços Públicos de Energia CSPE, criada pela Lei Complementar $n^{\circ} 833$, de 17 de outubro de 1997, deverá 
exercer o papel de regulador e fiscalizador, atuando sobre os serviços públicos de energia elétrica, em convênio com a ANEEL, e adicionalmente sobre o serviço de distribuição de gás canalizado.

Segundo ASSAD $(1997)^{8}$, os principais pontos da Lei que criou a CSPE abaixo relacionados, os quais ao nosso ver, deverão ser concretizados para o desempenho dessa instância regulatória:

- coibir a ocorrência de discriminação no uso e acesso a energia;

- $\quad$ proteger o consumidor no que respeita a preços, continuidade e qualidade do fornecimento de energia;

- aplicar metodologias que proporcionem a modicidade das tarifas;

- assegurar à sociedade amplo acesso a informações sobre a prestação dos serviços públicos de energia e as atividades da Comissão, assim como a publicidade das informações quanto à situação do serviço e aos critérios de determinação de tarifas;

- regular, controlar e fiscalizar a geração, produção, transmissão, transporte e distribuição de energia, naquilo que the couber originariamente ou por delegação;

- fazer observar, pelos concessionários de geração, o funcionamento do sistema interligado no Estado;

- aprovar níveis e estruturas tarifárias e homologar tarifas relativas aos serviços públicos de energia, tendo por objetivo a modicidade das tarifas e o equilíbrio econômico-financeiro das concessões e permissões;

- atuar no sentido de impedir práticas abusivas contra os interesses dos usuários de energia;

- moderar e dirimir conflitos de interesses, relativos ao objeto das concessões, permissões e autorizações, envolvendo concessionários, permissionários e

\footnotetext{
${ }^{8}$ Anotações do autor de palestra apresentada no Seminário: Qualidade de Serviços ao cliente. CESP, Atibaia,
1997.
} 
autorizados, podendo se valer do apoio de peritos técnicos especificamente designados.

A CSPE buscará cumprir o seu papel a partir de um modelo de regulação da qualidade, através do controle de variáveis elétricas do produto e dos serviços comerciais prestados pelas empresas de distribuição de energia elétrica.

Os princípios do modelo proposto estão baseados no estabelecimento de um sistema que permita apurar, aferir e corrigir as variáveis observadas e na transparência e objetividade no controle da qualidade.

Para isso, destaca-se que com a Resolução SEE n 06, de 27 de fevereiro de 1997, São Paulo instituiu o Programa Estadual de Qualidade de Energia Elétrica.

Com enfoque na qualidade do produto, do serviço e do atendimento comercial, o controle sobre as empresas será executado em cima de indicadores e padrões aplicáveis a um único consumidor ou a grupos de consumidores, sendo implantado em etapas, de forma a conciliar diferentes estágios de performance existentes hoje entre as empresas, e atingir no futuro uma homogeneização da qualidade em todo o Estado. As concessionárias estatais já estão obrigadas a cumprir as metas de desempenho estabelecidas e para as privatizadas os mesmos procedimentos e regras integram o anexo aos contratos de concessão firmados com o Poder Concedente, conforme demonstrado no ANEXO II.

Ainda, segundo ASSAD, as diretrizes e premissas do novo modelo, podem ser assim traduzidos :

- maior atenção ao consumidor atendido em baixa e média tensões;

- $\quad$ regras definidas previamente;

- $\quad$ aprimoramento dos instrumentos de avaliação usuais; 
- $\quad$ preservação dos atuais níveis de qualidade;

- política de consequências pelo descumprimento das regras estabelecidas;

A legislação, até aqui vigente, no que tange a regulação da qualidade, apresenta padrões deslocados do mercado, com indicadores que apenas funcionam como meros sinalizadores, tais como: duração de interrupções, frequência de interrupções, niveis de tensão e principais prazos comerciais.

Além disso, os critérios de apuração são inadequados ou insuficientes. Outro fato que merece destaque é a total ausência de fiscalização e responsabilização pelo órgão regulador. A inexistência de canal de comunicação entre os consumidores atendidos e o órgão regulador, completa o ciclo frágil da prestação dos serviços de distribuição de energia elétrica.

A organização da Ouvidoria pela CSPE, expediente também utilizado pela ANEEL, deverá criar as condições necessárias a comunicação dos consumidores com o órgão regulador. Deve-se esperar, também, que uma ação efetiva da CSPE, venha promover o incremento da participação dos Conselhos de Consumidores já implantados nas empresas distribuidoras.

A proximidade do órgão regulador do mercado, deverá tornar mais fácil e efetiva a mediação de conflitos entre as empresas e os consumidores.

Ainda, no intuito de criar um instrumento de regulação dos serviços de energia, no novo ambiente pós privatização, tramitou na Assembléia Legislativa do Estado de São Paulo, um Projeto de Lei do Deputado Rui Falcão para instituição do CONSESPE - Conselho Estadual de Serviços Públicos de Energia, cujos pontos de destaque constam do ANEXO III. 


\subsection{A REGULAÇÃO E A DEFESA DA CONCORRÊNCIA}

De forma a garantir um adequado funcionamento do novo modelo da indústria de energia no Brasil, o Sistema Brasileiro de Defesa da Concorrência SBDC, integrado pela Secretaria de Acompanhamento Econômico - SEAE (Ministério da Fazenda), a Secretaria de Direito Econômico - SDE e o Conselho Administrativo de Defesa Econômica - CADE (Ministério da Justiça), tem a função de estimular práticas e estruturas competitivas de mercado, coibindo abusos e buscando permitir que a sociedade usufrua dos benefícios proporcionados pelas mudanças.

Com a promulgação da Lei no. 9648 , de Maio de 1998, foi estabelecido no texto que a ANEEL deveria articular-se com a SDE para propiciar a concorrência efetiva entre os agentes e a impedir a concentração econômica nos serviços e atividades, cabendo também à ANEEL zelar pelo cumprimento da legislação de defesa da concorrência. Dentro desse princípio o CADE está desenvolvendo um projeto para estruturar o seu relacionamento com as agências reguladoras dos setores de infra-estrutura, prevendo o treinamento de pessoal, troca de informações e elaboração de convênio operacional com as três agências já instaladas: ANEEL, de telecomunicações - ANATEL, e de petróleo - ANP.

$O$ trabalho do projeto mencionado não se limita às agências reguladoras na esfera federal. A Agência Estadual de Regulação dos Serviços Públicos Delegados do Rio Grande do Sul - AGERGS, está firmando um convênio com o CADE para troca de informações, que a ajudará na obtenção de dados sobre o andamento de questões concorrenciais em diversas áreas. A agência gaúcha atua na regulamentação de serviços públicos em rodovias, portos, hidrovias, distribuição de energia elétrica e de gás canalizado, saneamento, irrigação e inspeção de veículos. 
Como fruto de articulações, iniciadas anteriormente pelo DNAEE, com o CADE, a SDE e a SEAE, a ANEEL emitiu a Resolução $n^{\circ}$ 094, de 30 de março de 1998, estabelecendo condições relativas à participação dos Agentes de Geração e de Distribuição nos serviços e atividades de energia elétrica, limitando a determinados percentuais a atuação no mercado nacional e no sistema regional.

Com isso, poderão estar criadas as condições essenciais parar uma efetiva concorrência entre os agentes, impedindo a concentração econômica nos serviços e atividades de energia elétrica, de modo a proteger e defender os interesses do cidadão e do consumidor.

\subsection{A INDÚSTRIA DE ENERGIA ELÉTRICA NO BRASIL E OS DIREITOS DO
CONSUMIDOR}

\subsubsection{Antecedentes históricos}

A exposição de motivos, constante do anteprojeto do Código de Águas, demonstra a extensão dos estudos para formular aquele trabalho, contemplando a situação existente em outros países, como os Estados Unidos, Alemanha, Inglaterra e Canadá, e o cuidado com o controle do Poder Público sobre a exploração da indústria hidrelétrica (CÓDIGO DE ÁGUAS, 1980).

Tal controle enfatizava a possibilidade de uma socialização potencial, avaliada pelo autor em função da afirmação de Frederic Sackett, embaixador americano na Alemanha, feitas na Segunda Conferência Mundial de Energia, realizada em Berlim, em 1930: "Se o Governo Federal possuísse e operasse as usinas de seus rios navegáveis, ligadas como podiam ser em uma numerosa rede, os benefícios dos preços baixos seriam imediatamente transferidos para o público consumidor" (CHAVES, 1998).

A mesma exposição de motivos cita a observação de Frederic Sackett de que "não existe outra indústria em que $\circ$ preço de venda seja tão 
extraordinariamente desproporcionado com o de produção, para a maioria dos consumidores, como sucede com a indústria do fornecimento de energia elétrica".

Exemplificando tal observação, foi mencionado que, na maioria dos centros populosos dos Estados Unidos, os consumidores pagavam em suas casas cerca de 6 cents, por kWh, que representava 15 a 20 vezes o seu custo.

São citados, no mesmo documento, outros exemplos de preços altos e a comparação com preços mais baixos praticados em países como a Alemanha, Inglaterra e Canadá, onde parte da exploração era feita pelo próprio Estado e já existia cooperação deste com as empresas.

Dando continuidade a sua exposição de motivos, o CÓDIGO DE ÁGUAS, referindo-se à questão no Brasil, dedicou todo um item sobre a concessão como caminho para a socialização, abordando prazos, amortização de capital e reversão para o Estado dos bens das empresas beneficiadas.

O CÓDIGO DE ÁGUAS destacou, ainda, a importância das Comissões de Serviços Públicos nos sistemas de controle sobre as empresas de utilidade pública, e não apenas das existentes nos Estados Unidos, mas em países como Itália e França onde se intensificava o controle do Estado sobre as empresas hidrelétricas, instituindo-se para isso órgãos especiais.

Concluindo a exposição com respeito ao Brasil, os autores do CÓDIGO DE ÁGUAS mencionaram a dificuldade encontrada na remodelação do seu projeto, pela vastidão e complexidade do assunto, por afetar os diversos ramos do direito e profundamente o interesse social e econômico, acrescentando que a regulamentação das empresas de utilidade pública era completamente desconhecida na literatura jurídica do País. 
Em síntese, a edição do Código de Águas (Decreto ${ }^{\circ} 24.643$, de 10 de julho de 1934) representava, segundo seus autores, "a ampliação do domínio público e do domínio federal sobre as águas e a regulamentação da indústria hidrelétrica", concretizando os cuidados com os aspectos econômicos e o interesse social.

O Código de Águas preocupava-se em regular o uso dos recursos hídricos, e dentro de um cenário institucional da indústria elétrica com predominância do capital estrangeiro, reforçava a posição do Estado no exercício do controle sobre as empresas, principalmente do ponto de vista econômico-financeiro. A introdução de estrutura tarifária baseada no custo do serviço, no qual já está incluso a remuneração do capital, mesmo encontrando, por um longo período, inúmeras barreiras para sua implementação, evitou exageros e impediu a evolução de preços como pretendiam as empresas (CHAVES, 1998).

Além dos aspectos relacionados à tarifa, a legislação ocupou-se mais intensamente da ação fiscalizadora sobre as empresas, mesmo quando no art. 178 do Código especifica o objetivo de "assegurar serviço adequado", que é explicado no art. 179:

"Quanto ao serviço adequado a que se refere a alínea "a" do artigo precedente, resolverá a administração, sobre:

a) qualidade e quantidade do serviço;

b) extensões;

c) melhoramentos e renovações das instalações;

d) processos mais econômicos de operação."

Com a regulamentação do Código de Águas através do Decreto n 41.019, de 26 de fevereiro de 1957, surgiram princípios mais claros sobre os cuidados com a qualidade dos serviços e 0 atendimento aos consumidores, conforme se verifica em parte do artigo 119 e do artigo 120 : 
"Art. 119. O regime legal e regulamentar da exploração dos serviços de energia elétrica tem por objetivo:

a) assegurar um serviço tecnicamente adequado às necessidades do País e dos consumidores;

b) estabelecer tarifas razoáveis para a sua remuneração;

c) garantir a estabilidade econômica e financeira das empresas.

Art. 120. Compete à Administração Pública resolver sobre:

a) as condições técnicas, a qualidade e quantidade do serviço;

b) as condições de utilização mais racional e econômica das instalações;

c) o acréscimo da capacidade das instalações e o seu equipamento mais eficiente;

d) a extensão do serviço."

No capítulo II, que trata das Normas Técnicas dos Serviços, nos artigos 123 ao 130 estão listados vários critérios e determinações sobre a freqüência e tensão de fornecimento, sobre medição da energia e características de sua precisão e, ainda, a restrição aos concessionários de não modificarem, por sua própria iniciativa, quaisquer características dos fornecimentos de energia elétrica (art. 130).

O Decreto $n^{0} 62.724$, de 17 de maio de 1968, alterado posteriormente pelos Decretos $n^{\text {os }} 75.887$, de 20.06.75, 86.463, de 13.10.81, e 95.459, de 10.12.87, mudou dispositivos do Código de Águas, mas ficou restrito mais às normas gerais de tarifação e classificação de consumidores(CHAVES,1998).

Entretanto, o início de um tratamento mais detalhado dos direitos e deveres do consumidor passou a existir com a edição da Portaria Ministerial $n^{\circ} 670$, de 08 de outubro de 1968, que estabeleceu condições de fornecimento de energia elétrica. 
Este documento, aprimorado com as revisões pelas Portarias do MME de $n^{\circ}$ 378, de 26.03.75, e as do Diretor Geral do DNAEE, de ${ }^{\text {os }} 095$ de 17.11 .81 (também abrangendo a classificação de consumidores, antes contidas nas Portarias MME 377, de 26.03.75, e 958, de 06.08.76); 222, de 22.12.87, e atualmente a 466, de 12.11.97, que entrou em vigor no dia 01 de janeiro deste ano, hoje denominada Condições Gerais de Fornecimento de Energia Elétrica.

\subsubsection{O Código de Defesa do Consumidor}

A evolução recente foi, sem dúvida, muito influenciado pelo Código de Defesa do Consumidor, determinado pela Constituição Federal promulgada em 05 de outubro de 1988, que no art. 48 do Ato das Disposições Transitórias estabeleceu o prazo de 120 dias para elaboração do código, editado pela Lei $n^{\circ}$ 8.078 de 11 de setembro de 1990 , e que entrou em vigor após 180 dias. Seus pontos de atenção constam do ANEXO IV, dos quais destacamos os seguintes:

a. Definições de Consumidor, Fornecedor, Produto e Serviço.

O Setor Elétrico possui legislação específica. Daí surgirem dúvidas quanto a abrangência das concessionárias e seus consumidores pelo texto do Código de Defesa. Essas dúvidas aumentam quando se faz a leitura dos artigos $37 \mathrm{e}$ 175 da Constituição Federal. O parágrafo 3 do art. 37 estabelece que "as reclamações relativas à prestação de serviços públicos serão disciplinadas em lei" e ou inciso II , do parágrafo único, do artigo 175 determina que a lei disporá sobre os direitos dos usuários de serviços públicos.

Porém, não é esta a devida interpretação a ser dada ao texto constitucional, pois, lei própria estabelecerá os direitos dos usuários, assim como a obrigação de ser mantido o serviço adequado, as tarifas e outras, independentemente da lei de âmbito geral e social, como traduzida no Código de Defesa do Consumidor. 
Assim, e tendo em vista, ainda, que a energia elétrica é um bem móvel e imaterial e, portanto, um produto, se dá como inquestionável a inclusão dos usuários e concessionárias desse produto nas definições de consumidor e de fornecedor dadas pelo Código.

Por ser o consumidor o destinatário final, as concessionárias distribuidoras estão excluídas dessa condição, inviabilizando reivindicações baseadas no Código. Isto, é obvio, somente no que diz respeito à compra de energia elétrica das produtoras. Nas demais relações de troca com o mercado (aquisição de bens e serviços) as concessionárias em geral podem se valer do Código para garantir seus direitos.

O art. 10 da Portaria DNAEE 222, de 22/12/87, define como consumidor "a pessoa física ou jurídica, ou comunhão de fato ou de direito legalmente representada, que solicitar ao concessionário o fornecimento e assumir a responsabilidade pelo pagamento da contas e pelas demais obrigações legais, regulamentares e contratuais". (destaques nossos).

O texto da Portaria deverá ser alterado para ficar em consonância com a lei 8078 (Código de Defesa do Consumidor).

b. Direitos Básicos do Consumidor

O Setor fornece ao mercado um produto extremamente útil e versátil: A energia elétrica. É também um produto seguro desde que utilizado de forma adequada. Pode ser que, a partir do advento do Código, esse detalhe tenha se tornado um elo frágil nas relações concessionárias e consumidores, visto que, estes nem sempre estão conscientizados dos riscos que a eletricidade oferece. 
Por ser subjetivo, o conceito de "prestação adequada e eficaz dos serviços públicos em geral" leva a crer que os parâmetros serão definidos em legislação própria. No caso do Setor Elétrico, esses parâmetros já estão estabelecidos por exemplo, pelas Portarias DNAEE no. 046 e no. 047, ambas de 17/04/78, esta última alterada pela Portaria DNAEE no. 404 de 10/01/84. Evidentemente tais parâmetros deverão ser revisados dada a evolução das exigências dosa consumidores e avanços tecnológicos.

A inversão do ônus da prova tem sido um dos aspectos mais polêmicos do Código de Defesa do Consumidor. A impressão geral era de que essa questão impunha ao fornecedor reclamado em qualquer circunstância a obrigação de produzir provas que o isentassem de responsabilidade. Assim, fosse o caso apresentado em qualquer esfera, judicial ou administrativa, submetia-se o fornecedor a julgamento por critérios meramente subjetivos, posto que a defesa dos consumidores realizava-se segundo as regras ordinárias da experiência.

Contudo, após análise mais atenta das disposições contidas no inciso VIII do Art. 6., da Lei $8078 / 90$ e de discussões sobre o tema mantidas com profissionais do PROCON/SP, podemos dizer que o Código considera direito básico do consumidor a facilitação da defesa dos seus direitos, permitindo até mesmo a inversão do ônus da prova a seu favor somente no processo civil, quando o juiz entender ser verossímil a alegação do consumidor e este não puder, dadas as suas condições pessoais, demonstrar que o produto ou serviço foi o causador do dano. Caberá então ao fornecedor, provar que não foi.

Isto significa que o texto legal não determina a inversão automática do ônus da prova, admitindo-a apenas no processo civil segundo critério s condições que especifica. 
Em termos práticos, o ponto em debate não acarretará prejuízo às para fundamentar suas defesas.

C. Responsabilidade por Danos

Quer na qualidade de produtoras, de distribuidoras ou de prestadoras de serviço público, as concessionárias poderão com base no Código de Defesa do Consumidor, ser responsabilizadas por danos causados e responder pela reparação dos mesmos.

Os art. 12, 13, 14 e 22 tratam da responsabilidade civil, respondendo pela reparação as pessoas jurídicas. No entanto, o art. 28 estabelece que "o juiz poderá desconsiderar a personalidade jurídica da sociedade quando, em detrimento do consumidor, houver abuso de direito, excesso de poder, infração da lei, fato ou ato ilícito ou violação dos estatutos ou contrato social. A desconsideração também será efetivada quando houver falência, estado de insolvência, encerramento ou inatividade da pessoa jurídica, provocados por má administração".

Apesar de não estar explicita, a ocorrência de casos fortuitos ou de força maior é válida para efeito de justificativa de eventuais problemas, que resultarem em danos para os consumidores.

Via de regra, as concessionárias investigam administrativamente os dados reclamados e suas causas, para fins de ressarcirem os casos em que se evidencie sua responsabilidade. Alias, este procedimento, de certo modo, já atende a inversão do ônus da prova.

Parece evidente e o bom senso assim recomenda, que não se espera de um serviço com tal envergadura e complexidade técnica, como é o caso da 
produção, transporte e distribuição de energia elétrica, manter-se absolutamente invulnerável à ocorrência de falhas de qualquer natureza.

Em função dessas características, o setor possui legislação própria que define o seu padrão de qualidade. É o caso das já citadas portarias DNAEE no. 046 e no. 047 , de 17/04/78, que estabelecem índices de continuidade e limites do oscilação de tensão, para o fornecimento de energia elétrica.

É nesse contexto que analisamos o artigo 22 do código, quando obriga os fornecedores de serviços públicos essenciais a fazê-lo de forma contínua.

Entretanto, as concessionárias em geral, mas principalmente aquelas que operam em sistemas isolados, devem se precaver ao máximo, evitando interrupções de fornecimento que possam ser interpretadas como decorrentes de falhas de cunho administrativo ou técnico, perfeitamente previsíveis e evitáveis.

Deve-se ter em conta, que os pedidos de indenização podem se estender para além do valor do bem danificado, incluindo danos pessoais e lucros cessantes.

O art. 26 estabelece que o direito de reclamar pelos vícios aparentes ou de fácil constatação ( problemas surgidos após a entrega do produto: variação de tensão, medição a maior, etc.) caduca em 30 dias contados a partir da entrega efetiva do produto (produto não durável).

Obstam a decadência:

- a reclamação comprovadamente formulada pelo consumidor perante o fornecedor, até a resposta negativa correspondente, que deve ser transmitida de forma inequivoca; 
- a instauração de inquérito civil, até seu encerramento.

O art. 27 determina que a pretensão à reparação pelos danos causados por fato de produto ou serviço (problemas na fabricação: não fornecimento - ou informaçōes insuficientes ou inadequadas sobre sua utilização e riscos) prescreve em 5 anos, contados a partir do conhecimento do dano de sua autoria.

d. Cobrança de Dívidas

Em princípio, pode-se ficar com a impressão de que a cobrança de contas de energia elétrica em atraso, mas principalmente o corte do fornecimento por falta de pagamento, tornar-se-iam procedimentos de execução, no mínimo, delicada, se analisados à luz dos artigos 42 e 71 do Código.

Na verdade, porém, suspender o fornecimento não se caracteriza como uma coação ao pagamento. Configura-se, isto sim como uma rescisão de contrato, visando proteger o patrimônio do fornecedor, no caso a concessionária, posto que interrompe o fornecimento futuro, face à inadimplência do consumidor.

De qualquer maneira, apesar de muitas concessionárias adotarem expedientes diversos no sentido de evitar a medida drástica do corte, deverão ser intensificados os cuidados com as tarefas relativas à cobrança de débitos, principalmente no que tange aos contatos pessoais com os consumidores.

Importante, também, a posterior organização do Sistema Nacional de Defesa do Consumidor - SNDC disposto no Decreto $n^{\circ} 861$, de 09.07.93, revogado pelo Decreto $n^{0} 2181$ de 20 de março de 1997. Como exemplo, destaca-se 
que entre os 14 casos que o SNDC passou a considerar como ações abusivas em março/98, dois afetam diretamente os prestadores de serviços de energia elétrica, que não poderão interromper o fornecimento por atraso no pagamento sem antes notificar o consumidor, e impor prazos de carência para retomar a prestação do serviço.

\subsubsection{Controle dos níveis de qualidade do produto e serviços}

A fixação das condições técnicas e dos parâmetros de qualidade do serviço de energia elétrica teve início com a edição das Portarias $n^{\circ s} 46$ e 47, de 17 de abril de 1978, estabelecendo as disposições relativas à continuidade dos serviços e aos níveis de variação de tensões, respectivamente. Aprimoradas com pequenas alterações pelas Portarias DNAEE $n^{\text {os }} 31$, de 11.04.80, 87, de 01.08.80, e 04 , de 10.01.89, foram os instrumentos de medição utilizados até hoje pelo órgão fiscalizador.

No âmbito do Estado de São Paulo, com a criação da Comissão de Serviços Públicos de Energia - CSPE, a qualidade do fornecimento de energia elétrica das empresas concessionárias, será controlada através de regras, padrões e procedimentos específicos. Serão implantados indicadores, de modo a não haver retrocesso nos niveis de qualidade, sendo os padrões, definidos e controlados de forma gradual e evolutiva.

Será requerida gradativamente a desagregação na base de cálculo dos indicadores, exigindo - se a apuração por tipo de atendimento - urbano e rural - e por agrupamentos ou segmentos de rede, sem descuidar do estabelecimento de valores máximos admissíveis a nível individual.

A relação dos indicadores, bem como os niveis dos padrões e critérios a serem exigidos das empresas distribuidoras de energia elétrica no Estado de São Paulo, encontram - se detalhados no ANEXO II. 


\subsubsection{O Conselho de Clientes}

Outro evento de fundamental importância foi a criação dos Conselhos de Consumidores, conforme determina o Art. 13 da Lei $n^{\circ} 8.631$, de 04.03 .93 , sendo regulamentado pela Portaria DNAEE $\mathrm{n}^{\circ} 519$, de 01.06.93, composto com representantes das principais classes de consumidores. Embora tenham caráter consultivo, os Conselhos, inclusive com a presença de representante do PROCON, estão voltados para a orientação, análise e avaliação das questões ligadas ao fornecimento, tarifas e qualidade dos serviços prestados ao consumidor final.

A título de exemplo descrevemos a seguir a composição do Conselho de Clientes da ELEKTRO Eletricidade e Serviços S/A, com representantes das seguintes entidades:
FIESP - Federação das Indústrias do Estado de São Paulo FCESP - Federação do Comércio do Estado de São Paulo PROCON
CONSABESP - Conselho das Associações de Bairros do Estado de São Paulo
FAESP - Federação de Agricultura do Estado de São Paulo
SECRETARIA DE ENERGIA
ELEKTRO

Participam, como observadores, representantes das seguintes entidades:

FECOERESP - Federação das Cooperativas de Eletrificação Rural do Estado de São Paulo

O funcionamento do Conselho de Clientes da ELEKTRO está baseado em seu regimento interno, conforme ANEXO V. 
O que se pode observar ao longo desses quase 5 anos de existência do Conselho, é que a sua origem, por estar vinculada ao cumprimento de um dispositivo legal, a participação dos representantes das diversas classes de consumidores, nem sempre foi caracterizada por um interesse espontâneo. Nos primeiros momentos de seu funcionamento, predominaram as iniciativas das Empresas concessionárias. Isso nos faz refletir sobre a necessidade de replicarmos os Conselhos de Clientes ao nível regional, no mínimo, para se garantir o envolvimento essencial dos clientes o mais próximo possível da prestação dos serviços. 


\section{CONCLUSÕES}

Do exposto neste trabalho infere-se que a organização do setor elétrico apresenta variantes ao longo da história quanto sua modelagem. No fim do século passado a exploração das quedas de água para fins de utilização de energia elétrica iniciou-se em nosso país sob a forma de concessões de serviço público. Os aspectos legais a ela pertinentes obedeciam ao sistema doutrinário europeu, sobretudo francês, enquanto modernamente, as concessões no campo da energia elétrica já passaram a receber o influxo da doutrina norte americana caracterizada pelo mecanismo das comissões regulamentadoras e ultimamente pelas correntes neo-liberais desenvolvida a partir da Inglaterra, procurando introduzir a competitividade e desregulamentação como uma forma de gerenciar as relações empresariais. Boa parte dos trabalhos foram desenvolvidos no Governo de Margareth Tatcher, aplicados inicialmente na América Latina no Chile, e são base do projeto de reestruturação que hoje passa o setor elétrico nacional, trabalho esse desenvolvido, mais recentemente, pela consultora internacional Coopers and Lybrand.

A influência francesa sobre o regime administrativo e jurídico das nossas concessões de serviço público foi predominante, e pode se dizer exclusiva, em todo periodo imperial, e na republica até 1930 . Com a revolução de 30 , começam a surgir, de modo reiterado e constante, na legislação, na pratica administrativa, na doutrina nacional, os primeiros sinais de influência do Direito Norte Americano sobre o nosso. O Código de Águas, que pelo decreto no. 24.643 , de $10 / 7 / 34$ transformou-se em lei é a consolidação das novas mudanças conceituais na doutrina do Serviço Público com influência marcante por mais de 60 anos, tendo o mesmo sido preservado pelas Constituições Federais que se seguiram (1937,1946 e 1988).

Apesar de ampla ser a legislação estabelecida em função do Código de Águas, a regulamentação dos serviços de energia elétrica, que é um pressuposto 
básico, só veio a ocorrer com o decreto no. 41.019 de 26/2/57. Por outro lado, a Lei 3.890-A, de 1961 que criou a Eletrobrás, estabelecendo recursos específicos para a expansão da energia elétrica através do imposto único, centralizou no Governo Federal, de forma direta a atividade de produtor e distribuidor de energia elétrica, realizando estudos, projetos construções e operação de usinas e linhas de transmissão e distribuição.

$O$ atendimento ao cliente só foi regulamentado com a portaria no. 222 de 1966, alterada pela portaria no. 466 de 11/12/97. O Código de Defesa do Consumidor, criado pela Lei 8.078 editada em 11/9/90, regula os direitos dos clientes em todos os campos da atividade econômica, passando a ser um fundamental instrumento jurídico colocado a disposição dos cidadãos. A Lei no. 8.631, de 4/3/93, determinou que fossem criados pelas empresas os Conselhos de Clientes, de forma que os mesmos tivessem um canal para a participar e influenciar no processo decisório das empresas, inclusive em relação a qualidade do fornecimento dos serviços, bem como a seus preços.

O advento das Leis no. 8987, de 13 de Fevereiro de 1995 - Concessão do Serviço Público, no. 9074, de 7 de Julho de 1995 - Concessão no Setor Elétrico, e no. 9427, de 26 de Dezembro de 1996 -,instituição da ANEEL, criou um novo ambiente nas relações dos agentes do setor elétrico no País, mais condizente com o exercício do direito dos consumidores.

Esse ambiente naturalmente favorece a maior atuação dos órgãos de defesa do consumidor e da imprensa, haja visto as repercussões a respeito das falhas de atendimento e continuidade do serviço ocorridas no verão de 1998, no Estado do Rio de Janeiro, que levaram á tomada de uma série de medidas para solucionar os problemas, culminando com a aplicação pela ANEEL multa às duas concessionárias - LIGHT E CERJ. 
No entanto, a reestruturação em curso da indústria de energia elétrica, a desregulamentação do setor, com o pressuposto de que as regras de mercado e a competitividade estabelecerão novos paradgmas, poderão surgir desequilibrios e entraves nas relações entre clientes e empresas de energia elétrica. Em relação aos grandes clientes, com poder de negociação, o postulado acima expresso pode não ser verdadeiro. Entretanto, para os pequenos clientes, que fazem parte do chamado mercado cativo, é preciso que se desenvolvam mecanismos efetivos de proteção.

Nesse sentido, no âmbito nacional, a Agência Nacional de Energia Elétrica ANEEL, que embora com atribuições aderentes a fiscalização e controle necessários dos serviços, parece não demonstrar, ainda, articulação e autonomia suficientes para tal. Um fator essencial é que se reproduza, a partir do que pode ser observado da experiência desenvolvida nos Estados Unidos, mais especificamente no estudo de caso da PG\&E e na Inglaterra, que se crie uma entidade isenta, que será o fiscalizador e protetor dos interesses da sociedade.

No Estado de São Paulo, a criação da Comissão de Serviços Públicos de Energia, é uma iniciativa que poderá caminhar na direção de se constituir numa entidade de defesa dos interesses dos clientes de energia elétrica, desde que possa construir um efetivo processo fiscalizador dos serviços e se modifiquem os dispositivos legais que garantam a autonomia necessária da entidade.

Por outro lado, temos que considerar que o setor de energia elétrica pode ser considerado o que mais democratizou seus serviços, quando olhado da ótica do atendimento. Hoje mais de $92 \%$ dos domicilios do país estão ligados com energia elétrica, embora hajam grandes disparidades regionais. A eletrificação rural caminha a passos largos, e nas regiões tradicionais é bastante alto. No Estado de São Paulo está próximo dos $80 \%$, e existe um programa de atendimento rural que se continuado, atingirá em breve a totalidade dos lares eletrificáveis por sistemas convencionais. Entretanto, a desregulamentação em curso não contempla 
compromissos que venham a garantir as necessidades de atendimento ao pequeno consumidor, mormente os de baixa renda, cuja situação poderá ser agravada pela privatização do setor, desatrelada de políticas públicas específicas.

Além dos aspectos legais, vemos que as empresas de energia elétrica poderão empreender ações na direção de promover um real ambiente de participação dos clientes em seu processo decisório. Com isso, o amadurecimento das relações comerciais entre clientes e empresa, tenderá a levar a um processo em que os interesses recíprocos serão preservados e, portanto, a presença do órgão regulador e fiscalizador passará a arbitrar apenas nas grandes questões institucionais, de caráter geral.

Dentro deste quadro finalizamos, recomendando, que os clientes busquem conhecer e influenciar o novo contexto em que se desenvolve a indústria de energia elétrica no país, identificando os mecanismos regulatórios que impactam a prestação do serviço de distribuição de energia elétrica. Em contrapartida, as Agências Reguladoras devem informar os clientes a respeito do novo modelo regulatório e suas implicações no dia a dia da prestação dos serviços, bem como estabelecer prática sistemática de fiscalização das empresas concessionárias, inclusive, promovendo e divulgando as ações por elas desenvolvidas, que estejam contribuindo para a contínua qualidade dos serviços. Quanto as empresas concessionárias, deverão empreender um plano sistemático de aproximação dos clientes, com metas claras e objetivas de participação do público em suas decisões. 


\section{BIBLIOGRAFIA}

ALMEIDA, Márcio Wohlers. Estado e energia elétrica em São Paulo: CESP, um estudo de caso. Dissertação de mestrado apresentada ao Departamento se Economia e Planejamento Econômico do Instituto de Filosofia e Ciências Humanas da Universidade Estadual de Campinas. Campinas, 1980.

ÁLVARES, Walter T.. Curso de Direito de Energia. Rio de janeiro, 1978.

ARANHA, Luíz Oswaldo Norris. A privatização das empresas distribuidoras. Trabalho de consultoria elaborado para a CESP, mimeo, 1991, 43 p..

ASSAD, Sérgio Luís. Seminário: Maximizando a satisfação dos clientes. CESP, Atibaia, 1997. (Anotações do autor de palestra apresentada).

ATKINSON, Graham. As lições da competição no modelo britânico de eletricidade. Revista Eletricidade Moderna, Outubro de 1996.

BAJAY, Sérgio e OLIVEIRA, Adilson. Desempenho e Reestruturação do setor elétrico em diversos países - elementos de reflexão para o caso brasilleiro. Escola de Administração de Empresas de São Paulo - Fundação Getúlio Vargas. São Paulo, 1996.

BAJAY, Sérgio et al.. Implantação da Comissão de Serviços Públicos de Energia no Estado de São Paulo, à luz da experiência internacional de regulação dos setores elétrico e de gás encanado. São Paulo, 1996.

BOBBIO, Norberto. O Futuro da Democracia - Uma Defesa das Regras do Jogo. $5^{\mathrm{a}}$ ed. Rio de Janeiro, Editora Paz e Terra, 1992.

BORENSTEIN, Raul Carlos, et al..O Setor Elétrico no Brasil - Dos desafios do passado às alternativas do futuro. Porto Alegre, Editora Sagra Luzzatto, 1997.

BRANCO, Catullo. Energia Elétrica e Capital Estrangeiro no Brasil. Editora Alfa Omega Ltda., São paulo, 1975. 
CALABI, Andréa S.. A energia e a economia brasileira. São Paulo, Livraria Pioneira Editora, 1983.

CHAVES, Celso Carlos. A evolução dos Direitos do consumidor de energia elétrica no Brasil. Monografia para o Curso de Especialização sobre o Novo Ambiente Regulatório, Institucional e Organizacional do Setor Elétrico. USP/UNICAMP/EFEI, 1998.

COOPERS \& LYBRAND. Projeto de Reestruturação do Setor Elétrico Brasileiro. Vol. 1 - Sumário Executivo. Rio de Janeiro, MME/ELETROBRÁS, Junho, 1997, $38 \mathrm{p}$.

DEPARTAMENTO NACIONAL DE ÁGUAS E ENERGIA ELÉTRICA, Brasília. Código de Águas, Volume I, 1980.

EDISON ELECTRIC INSTITUTE. Marketing Strategies Case Study - Vol. 8. USA, 1982

EDISON ELECTRIC INSTITUTE. Public Participation - Vol. 2. USA, 1982.

ELETROBRÁS. Boletim Semestral - Síntese 1997. Rio de Janeiro, 1998.

ELETROBRÁS. Plano 2015 - Perspectiva do mercado e da conservação de energia elétrica. Rio de Janeiro, 1992.

ELETROBRÁS. Plano Decenal de Expansão 1997/2006, Rio de Janeiro, 1997.

FALCÃO, Rui. Minuta do Projeto de Lei para criação do CONSESP - Conselho Estadual de Serviços Públicos de Energia. Assembléia Legislativa do Estado de São Paulo, 1995.

HENRIQUES, Luis Otávio A.. Indústria de eletricidade: modelo britânico busca competição. Revista Eletricidade Moderna, 42-49, 1994.

JOHNSON, Bruce B., et al. Serviços públicos no Brasil : mudanças e perspectivas. São Paulo: Editora Edgard Blücher, 1996. 
LEITE, Antonio Dias. A Energia do Brasil. Editora Nova Fronteira, Rio de Janeiro, 1997.

LIMA, José L.. Estado e energia no Brasil. IPE-USP, São Paulo, 1984.

MEIRELLES, Hely Lopes. Direito Administrativo Brasileiro. 14 Edição, Editora Revista dos Tribunais, São Paulo, 1989.

OLIVEIRA, Adilson. Reforma do Setor Elétrico: Que podemos aprender com a experiência alheia? IE-UFRJ, Rio de Janeiro, 1997.

RODRIGUES, ADRIANO P. \& DIAS, DANILO S. Estado e energia elétrica. Rio de Janeiro, Instituto Liberal, 1994.

ROSA, Luiz Pinguelli, et al..A reforma do setor elétrico no Brasil e no mundo. Rio de Janeiro, Editora Dumará Distribuidora de Publicações, 1998.

SANTOS, Ricardo Henrique. O planejamento integrado de recursos e a regulação: a experiência dos EUA e as perspectivas no Brasil. Dissertação de mestrado ao Programa de Pós-Graduação em Energia da USP. São Paulo, 1997.

SECRETARIA DE DEFESA DO CONSUMIDOR. Código de defesa do Consumidor e legislação correlata. São Paulo, 1991.

SECRETARIA DE ESTADO DE ENERGIA. Comissão de Serviços Públicos de Energia - Qualidade do fornecimento de energia elétrica - indicadores, padrões e penalidades. São Paulo, 1996.

STALON, Charles G.. O sistema americano: Um sistema mais privado de regulamentação de energia. Trabalho apresentado na Conferência dos Ministros, Cidade do México, 1991.

TENENBAUM Bernard, et al. Electricity privatization: strutural, competitive and regulatory options. UK, Energy Policy, vol. 20, num. 12, December, 1992. 
VIANNA, Eduardo da Cunha. Um estudo sobre as causas da crise do setor elétrico e do movimento em prol de sua privatização. Tese de mestrado do Programa de Pós-Graduação de Engenharia da Universidade Federal do Rio de Janeiro. Rio de Janeiro, 1991. 


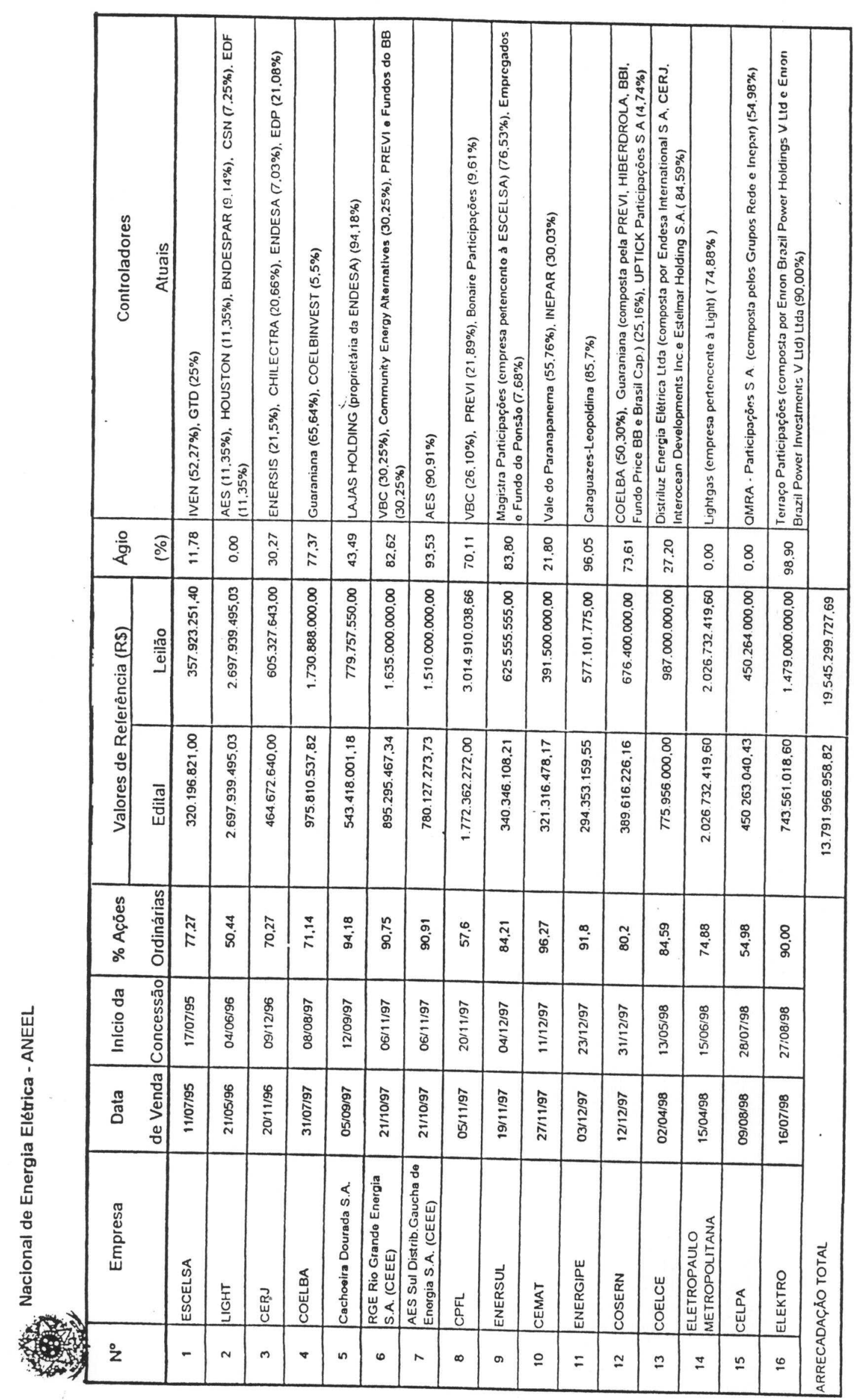


ANEXO II - Indicadores e parâmetros de qualidade do fornecimento de energia elétrica ( anexo aos contratos de
concessão)

\section{I - CONSIDERAÇÕES INICIAIS}

A sistemática de controle da qualidade do fornecimento de energia elétrica, aqui descrita, será implementada em etapas sucessivas, sendo contemplados três enfoques: a qualidade do produto, a qualidade do serviço e a qualidade do
atendimento comercial.

O controle da qualidade será executado considerando indicadores e padrões individuais e coltivos, sendo que a violação dos padrōes definidos poderăo gerar penalidades em favor deverão ser recolhidas ao órgão regulador, devenalidades em favor dos consumidores, assim como penalidades que recursos. Os procedimentos para coleta, análise e encaminhamento dos indicadores ao órgão regulador estão apresentados nos
Apêndices A, B, C, D e E, válidos para todas as etapas de implementaçăo detalhadas a seguir.

Para a adequada compreensão do exposto neste documento, deve-se considerar as seguintes definiçőes:

Consumidor atendido em tensăo de distribuição

Consumidor atendido em alta tensão

Consumidor atendido em baixa tensão

Consumidor atendido em média tensão

\section{II - ETAPAS DE IMPLEMENTAÇÃO}

a) para indicadores e padrōes da qualidade de serviço e do produto:

- Etapa de adaptação, que se inicia a partir da assinatura do Contrato de Concessão, estendendo-se até 31 de dezembro de 1998. Nesta etapa seräo definidos, pelo órgão regulador, novos agrupamentos de consumidores para avaliação dos indicadores previstos para as etapas subsequentes. Estes novos agrupamentos serão
denominados famílias de redes, estando conceituados no Apêndice F.

- Etapa de transição, que se inicia em $1^{\circ}$ de janeiro de 1999, estendendo-se até 31 de dezembro de 2001 . Nesta etapa será iniciada a constituiçăo da base de dados de novos indicadenta disponibilização terăo sido desenvolvidos na etapa novos indicadores, cujos sistemas e procedimentos para metodologias para controle da qualidade da forma de adaptação. Serão, ainda, procedidos estudos de ELEKTRO deverá dispor de informaçőes, medições de onda e de fenômenos transitórios. Deste modo, a

da legislação vigente, que se inicia em $1^{\circ}$ de janeiro de 2002 e na qual se realizará o controle dos indicadores mecânica de controle adotada nas etapase histórica foi preparada na etapa de transição. Alterar-se-á a metodologias para controle da qualidade da formaptaçăo e de transição e iniciar-se-á a aplicação das

b) para indicadores e padrões da qualidade do atendimento comercial:

- Etapa de adaptação, que se inicia a partir da assinatura do Contrato de Concessão, estendendo-se até 31 de indicador de 1998. Nesta etapa iniciam-se os trabalhos para a definição de metodologia para a apuração do indicador de perdas comerciais, a ser controlado na próxima etapa.

- Etapa de maturidade, que se inicia em $1^{\circ}$ de janeiro de 1999 , durante a qual será mantido o controle dos mesmos indicadores, adotando-se novos padrões de qualidade. Nesta etapa as perdas comerciais passam a
ser também controladas.

\section{III - INDICADORES DE QUALIDADE DO PRODUTO E DE SERVIÇO}

a) Nivel de Tensão 
A tensão no ponto de entrega de cada unidade consumidora será controlada através de auditorias e do atendimento a reclamaçōes de consumidores, implicando em processo de medição cujos critérios são apresentados no Apêndice $\mathrm{A}$.

b) DEC e FEC - Duração e Frequência Equivalente de Interrupção por Consumidor

Os indicadores DEC e FEC previstos nesta etapa são os definidos pela portaria $n^{\circ} 046$ do DNAEE, de 17/04/78, considerando interrupçöes superiores a 1 minuto.

c) FMA, TMA e T80\% - Freqüência Média, Tempo Médio e Tempo $80 \%$ de Atendimento de Emergência

d) TA - Tempo de Atendimento

Os tempos de atendimento serão controlados através de auditorias, motivadas ou não por reclamações de consumidores.

e) DIC e FIC - Duração e Freqüência de Interrupção Individual

Os indicadores DIC e FIC serão controlados através de auditorias motivadas ou não por reclamaçōes de
consumidores.

\section{I.1.1.1 2 - Indicadores para a Etapa de Transição}

\section{I.1.2 III.2.a - Indicadores Controlados}

Os indicadores controlados nesta etapa serão os mesmos da etapa de adaptação, acrescidos dos indicadores correlaçăo entrelvando-se que, na apuração dos indicadores DEC e FEC, não mais poderá ser utilizada a adaptação. Ressalve-se, também, que o indicador T80\%, nesta etapa, passa a ser substituído por T90\%, para todos os
consumidores.

Mediante estudos e análises especificas a serem conduzidas nesta etapa, serão definidos pelo órgão regulador os procedimentos para controle de indicadores referentes à qualidade do produto, no que diz respeito à forma determinação das perdas codologia para o cálculo das perdas técnicas, que por sua vez serão utilizadas para a

\section{I.2 III.3 - Indicadores Controlados durante a Etapa de Maturidade}

A tabela I, abaixo, apresenta a relação de indicadores a serem controlados.

tabela I - indicadores controlados na etapa de maturidade

a) já definidos

\begin{tabular}{l|l|l}
\hline \multicolumn{1}{|c|}{ Indicador } & \multicolumn{1}{c}{ Abrangência } & \multicolumn{1}{c}{ Período de Apuração } \\
\hline Nivel de tensão & Individual & Reclamação ou Auditoria \\
\hline DIC & Individual & Reclamação ou Auditoria \\
\hline FIC & Individual & Reclamação ou Auditoria \\
\hline TA & Individual & Reclamação ou Auditoria \\
\hline DEC & $\begin{array}{l}\text { ELEKTRO/Areas de Apuração/ } \\
\text { Conjuntos/Familias }\end{array}$ & Mensal/Trimestral/Anual \\
\hline FEC & $\begin{array}{l}\text { ELEKTROAreas de Apuração/ } \\
\text { Conjuntos/Famílias }\end{array}$ & Mensal/Trimestral/Anual \\
\hline FDT & ELEKTRO & Trimestral/Anual \\
\hline FEV & ELEKTRO & Trimestral/Anual \\
\hline FMA & ELEKTRO/Areas de Apuração/Famílias & Mensal/Anual \\
\hline TMA & ELEKTRO/Areas de Apuração/Famílias & Mensal/Anual \\
\hline T90\% & ELEKTRO/Areas de ApuraçãoFamilias & Mensal/Anual \\
\hline
\end{tabular}


b) a definir

\begin{tabular}{|c|c|}
\hline Indicador & Abrangência e Período de Apuração \\
\hline Variaçōes temporárias de frequêencia & A definir na $2^{\mathrm{a}}$ etapa \\
\hline Conteúdo harmônico & A definir na $2^{a}$ etapa \\
\hline Interrupção de curta duração & A definir na $2^{a}$ etapa \\
\hline Flutuação de tensão & A definir na $2^{a}$ etapa \\
\hline Desequilíbrios de tensão & A definir na $2^{a}$ etapa \\
\hline Variação de tensão de curta duração & A definir na $2^{a}$ etapa \\
\hline Variação de tensão de longa duração & A definir na $2^{a}$ etapa \\
\hline $\begin{array}{l}\text { Variação momentânea de tensão } \\
\text { Perdas técnicas }\end{array}$ & A definir na $2^{2}$ etapa \\
\hline Perdas técnicas & A definir na $2^{a}$ etapa \\
\hline
\end{tabular}

\section{IV - PADRŐES DE QUALIDADE DO PRODUTO E DE SERVIÇO}

\section{I.3 IV.1 - Padrões para a Etapa de Adaptação}

a) Niveis de Tensão para Consumidores Atendidos em Alta Tensão

Os niveis adequados de tensão deverăo estar entre os seguintes valores:

tabela II - limites máximos e mínimos adequados de tensão - AT

\begin{tabular}{|c|c|c|}
\hline \multirow{2}{*}{$\begin{array}{l}\text { Tensão Nominal } \\
\text { do Sistema } \\
\text { (kV) }\end{array}$} & \multicolumn{2}{|c|}{ Tensão de Fornecimento no Ponto de Entrega } \\
\hline & $\begin{array}{c}\begin{array}{c}\text { Valor Mínimo } \\
(\mathrm{kV})\end{array} \\
\end{array}$ & $\begin{array}{c}\text { Valor Máximo } \\
(\mathrm{kV})\end{array}$ \\
\hline 69 & 65,6 & 72,5 \\
\hline 88 & 82,0 & 93,0 \\
\hline 138 & 131,0 & 145,0 \\
\hline 230 & 218,0 & 241,5 \\
\hline
\end{tabular}

Os limites precários de tensão corresponderão a $90 \%$ das correspondentes tensões nominais do sistema.

b) Niveis de Tensão para Consumidores Atendidos em Média Tensão

A tensão de fornecimento deverá situar-se na faixa entre mais $5 \%$ e menos $5 \%$ da tensão nominal e, ainda,
coincidir com um dos terminais de derivação previamente exigido ou recomendado do consumidor.

Os limites adequados para a tensão deverão ser de mais $5 \%$ e menos $7,5 \%$ em relação à tensão de
fornecimento.

c) Niveis de Tensão para Consumidores Atendidos em Baixa Tensão

Os limites máximos e mínimos para tensão de fornecimento aos consumidores ligados à rede de baixa tensão para faixas de valores considerados adequados e precários, são aqueles estabelecidos pelas portarias $n^{\circ} 047$ $n^{\circ} 4$ do DNAEE, de 17/04/78 e 10/01/89, respectivamente.

\section{d) DEC e FEC - Duração e Frequência Equivalentes de Interrupção}

Os indicadores anuais, referentes à ELEKTRO como um todo e cada uma de suas respectivas Áreas de Apuração, não deverão ultrapassar as suas próprias médias, relativas aos anos de 1993, 1994 e 1995 tomando-se os valores anuais obtidos ao término do mês de dezembro de cada um deles. Os indicadores de cada conjunto năo deverăo ultrapassar suas respectivas médias, calculadas de forma análoga, acrescidas de $30 \%$, não podendo ser ultrapassados, também, os limites estabelecidos pela portaria $n^{\circ} 046$ do DNAEE, de
$17 / 04 / 78$, por tipo de conjunto. Os indicadores mensais, para a ELEKTRO como um todo e cada uma de suas Áreas de Apuração, não deverão
ser superiores a 1/5 (um quinto) dos respectivos padrões anuais.

Para cada um dos conjuntos, os indicadores mensais e trimestrais não poderăo ser superiores, respectivamente, a $1 / 4$ (um quarto) e a $3 / 4$ (três quartos) dos padrōes anuais correspondentes, respeitados os

e) FMA, TMA e T80\% - Frequência Média, Tempo Médio e Tempo $80 \%$ de Atendimento de Emergência 
Os padröes de FMA e TMA para a ELEKTRO como um todo e cada uma de suas respectivas Áreas de Apuração, serão as correspondentes médias referentes aos anos de 1993, 1994 e 1995, tomando-se os valores anuais obtidos ao término do mês de dezembro de cada um deles, conforme tabela abaixo.

Os valores T80\%, contidos na mesma tabela, são estabelecidos com base na série histórica de 1995 e 1996.

\section{f) TAI - Tempo de Atendimento Individual}

O Tempo de Atendimento Individual não poderá ultrapassar os seguintes limites:

- consumidores atendidos em tensão inferior a 69 kV, localizados na área urbana: 12 horas;

- consumidores atendidos em tensão inferior a 69 kV, localizados na área rural: 15 horas;

- consumidores atendidos em tensão igual ou superior a $69 \mathrm{kV}: 2$ horas.

\section{g) DIC e FIC - Duração e Frequência de Interrupção Individual}

Os padrões anuais, trimestrais e mensais de DIC e FIC estăo apresentados na tabela VI.

Tais padrōes foram determinados através de procedimento estatístico, considerando os valores apurados no ano de 1995, não superados por cerca de $99 \%$ dos consumidores envolvidos.

\section{IV.2 - Padrões para a Etapa de Transição}

a) Niveis de Tensão

Todos os padrões de niveis de tensão da etapa de adaptação deverão ser mantidos.

b) DEC e FEC - Duração e Frequência Equivalente de Interrupção por Consumidor Na etapa de transiçăo, os padrões anuais de DEC e FEC, para a ELEKTRO como um todo, serăo os menores
valores dentre:

- as correspondentes médias das médias anuais dos valores verificados nos anos civis de 1996, 1997 e 1998, em cada uma de suas Áreas de Apuração, ponderadas pelos respectivos números de consumidores existentes ao final de cada um deles;

- as correspondentes médias das médias dos valores anuais verificados nos anos civis de 1996, 1997 e 1998 em todas as empresas concessionárias de distribuição de energia elétrica do Estado de São Paulo, ponderadas pelos respectivos números de consumidores existentes ao final do período;

- os padrōes vigentes durante a etapa de adaptaçăo.

No que se refere a suas Áreas de Apuração, os indicadores anuais de DEC e FEC, para cada uma delas, não deverăo ultrapassar as suas próprias médias, relativas aos anos civis de 1996, 1997 e 1998, tomando-se os valores anuais obtidos ao término de cada ano civil.

No caso dos conjuntos de consumidores definidos pela portaria $n^{\circ} 046$ do DNAEE, os indicadores anuais de 1997 e 1998 , para cada um deles, não deverão ultrapassar as suas próprias médias, relativas aos anos de 1996

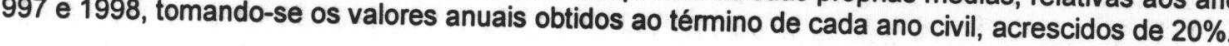

Se os valores apurados forem superiores aos padrões anuais adotados durante a etapa de adaptação, serão mantidos estes últimos também para a etapa de transição. Os indicadores mensais, para a ELEKTRO como um todo e cada uma de suas Áreas de Apuração, não deverão
ser superiores a 1/6 (um sexto) dos correspondentes padrões anuais.

Para cada um dos conjuntos, os indicadores mensais e trimestrais não poderão ser superiores, respectivamente, a $1 / 4$ (um quarto) e a 3/4 (três quartos) dos padrōes anuais correspondentes, respeitados os limites impostos pela portaria $n^{\circ} 046$ do DNAEE, de 17/04/78.

Caso a ELEKTRO năo se enquadre nos padrões de DEC e FEC definidos para a concessionária como um todo deverá tomar providências para se ajustar num prazo de 36 (trinta e seis) meses, considerando recuperação de $20 \%$ até o final do primeiro ano, mais $30 \%$ até o final do segundo e os últimos $50 \%$ até o final do terceiro ano. 
Os indicadores anuais de FMA e TMA, para a ELEKTRO como um todo e cada uma de suas respectivas Áreas de Apuração, não deveräo ultrapassar as suas próprias médias, referentes aos anos de 1996, 1997 e 1998, tomando-se os valores anuais obtidos ao término de cada ano civil.

Se os valores apurados forem superiores aos padrőes anuais adotados durante a etapa de adaptação, serão mantidos estes últimos também para a etapa de transiçăo.

Para consumidores localizados na área urbana, os padrőes mensais corresponderão:

- para FMA - a 1,4 vezes o respectivo padrão anual, dividido por 12;

- para TMA - a 1,4 vezes o respectivo padrăo anual.

Para consumidores localizados na área rural os padrőes mensais corresponderão:

- para FMA - a 1,6 vezes o respectivo padrão anual, dividido por 12;

- para TMA - a 1,4 vezes o respectivo padrăo anual.

d) T90\% - Tempo 90\% de Atendimento de Emergência

Para a ELEKTRO como um todo e cada uma de suas respectivas Áreas de Apuração, os valores anuais de T90\%, que substitui T80\% nesta etapa, não deverăo ultrapassar as suas próprias médias, referentes aos anos de 1996, 1997 e 1998, tomando-se os valores anuais obtidos ao término de cada ano civil.

Se os valores apurados forem superiores aos padrões anuais adotados durante a etapa de adaptação, serão mantidos estes últimos também para a etapa de transiçăo.

Os padrőes mensais de T90\% corresponderão a 1,4 vezes os respectivos padrões anuais.

e) TAI - Tempo de Atendimento Individual

O Tempo de Atendimento Individual năo poderá ultrapassar os seguintes limites:

- consumidores atendidos em tensão inferior a 69 kV, localizados na área urbana: 11 horas;

- consumidores atendidos em tensão inferior a 69 kV, localizados na área rural: 14 horas;

- consumidores atendidos em tensão igual ou superior a $69 \mathrm{kV}: 2$ horas.

f) DIC e FIC - Duração e Frequência de Interrupção Individual

Os padrões anuais de DIC e FIC serão apurados através de procedimento estatístico, considerando os índices verificados nos anos civis de 1996, 1997 e 1998, năo superados por um valor a ser definido pelo órgão uma de sus entre $98,5 \%$ e $99,5 \%$ dos consumidores envolvidos, para a ELEKTRO como um todo e cada uma de suas respectivas Áreas de Apuração, respeitados os limites fixados pela portaria $n^{\circ} 046$ do DNAEE, de
$17 / 04 / 78$. Se os valores apurados forem superiores aos padrões anuais adotados durante a etapa de adaptação, serão
mantidos estes últimos também para a etapa de transição.

Os padrōes mensais corresponderão a 0,4 vezes os respectivos padröes anuais.

Os padrões trimestrais serão os menores dentre os seguintes valores:

- 3 vezes os respectivos padrões mensais;

- os limites impostos pela portaria $n^{\circ} 046$ do DNAEE, de 17/04/78.

g) FEV e FDT - Frequência Equivalente de Violação de Tensão e Função Distribuição de Tensão

Os procedimentos para análise e fixação de padröes relativos à adequação da tensão de fornecimento, vista de modo coletivo, serão resultantes de avaliações a serem realizadas durante o transcorrer das etapas de
adaptaçăo e de transiçăo. Deste modo, serão considerados como padrão de FEV e como referência de FDT, nesta etapa, os valores
verificados no transcorrer do último ano da etapa de adaptaçăo. 

A etapa de transição deverá apresentar nível de qualidade de tensão igual ou superior ao nível verificado na
etapa anterior, tido como nível de referência.

O nível de qualidade de referência será determinado pelo produto da FDT, obtida na etapa de adaptação, pela FCIT - Função Custo da Imperfeição da Tensão, obedecido o procedimento descrito no item sobre Penalidades.

\section{I.4 IV.3 - Padrões para a Etapa de Maturidade}

Esta etapa é caracterizada pelo alcance do nível pleno de instrumentos, procedimentos e padrões para o completo controle da qualidade do fornecimento de energia elétrica.

Os indicadores introduzidos nas etapas anteriores, inclusive as sistemáticas de controle das perturbações na forma de onda, bem como os padröes fundamentados nas bases históricas constituídas e, ainda, a consideração de famílias de redes com atributos semelhantes, ao lado dos atuais conjuntos, constituem o ambiente de permanência

\section{a) Níveis de Tensão}

Todos os padrões de níveis de tensão da(s) etapa(s) anterior(es) deverăo ser mantidos.

b) DEC, FEC, FMA, TMA e T90\% - Duração e Frequência Equivalente de Interrupção por Consumidor, Frequência Média e Tempo Médio de Atendimento de Emergência e Tempo $90 \%$ de Atendimento de Emergência

Nesta etapa deverá ser verificada, considerando-se a ELEKTRO como um todo, a observância do menor dentre os seguintes valores anuais de DEC e FEC, referidos ao mês de dezembro:

- as correspondentes médias das médias anuais dos valores verificados no mês de dezembro de cada ano da etapa de transição, em cada uma de suas Áreas de Apuração, ponderadas pelos respectivos números de consumidores existentes ao final de cada um deles;

- as correspondentes médias das médias dos valores anuais verificados no mês de dezembro dos anos da etapa de transição, em todas as empresas concessionárias de distribuição de energia elétrica do Estado de Săo Paulo, ponderadas pelos respectivos números de consumidores existentes ao final do período:

- os padrões vigentes durante a etapa de transiçăo.

No que se refere a suas Áreas de Apuração, os indicadores anuais de DEC e FEC, para cada uma delas, não deverão ultrapassar as suas próprias médias, relativas aos anos da etapa de transição, tomando-se os valores anuais obtidos ao término do mês de dezembro de cada um deles.

Se os valores apurados forem superiores aos padrões anuais adotados durante a etapa de transição, serão mantidos estes últimos também para a etapa de maturidade. Os padrōes mensais de DEC e FEC, para a ELEKTRO como um todo e cada uma de suas Áreas de Apuração,
corresponderão a $1 / 4$ (um quarto) dos padrōes anuais.

Para os conjuntos de consumidores, os padrões anuais, trimestrais e mensais de DEC e FEC serão os mesmos da etapa anterior, respeitados os limites impostos pela portaria $n^{\circ} 046$ do DNAEE, de 17/04/78.

No que se refere a FMA e TMA, os correspondente indicadores anuais, para a ELEKTRO como um todo e cada uma de suas respectivas Áreas de Apuração, não deverăo ultrapassar as suas próprias médias, referentes aos deles. Se os valores apurados forem superiores aos padrōes anuais adotados durante a etapa de transição, serão
mantidos estes últimos também para a etapa de maturidade.

Os padrões mensais de FMA e TMA corresponderão:

- para FMA - a 1,3 vezes o respectivo padrão anual, dividido por 12;

- para TMA - a 1,3 vezes o respectivo padrão anual.

Os padrões anuais e mensais de T90\%, para a etapa de maturidade, são as correspondentes médias dos valores de T80\% verificados nos três anos da etapa de transição, para a ELEKTRO como um todo, cada uma de suas correspondentes Áreas de Apuraçăo e familias de redes. 

Se os valores apurados forem superiores aos padrões vigentes durante a etapa de transição, serão mantidos
estes últimos também para a etapa de maturidade.

Os padrões mensais de T90\% corresponderăo a 1,3 vezes os respectivos padrões anuais.

Durante toda a etapa de transição deverão ser apurados os indicadores DEC, FEC, FMA, TMA e T90\% para cada uma das redes elementares pertencentes a cada uma das famílias de redes existentes na ELEKTRO.

De posse desses indicadores, deverão ser elaboradas e encaminhadas ao órgão regulador, mensal e trimestralmente, as distribuiçőes acumuladas de frequências de ocorrências para cada um deles, sendo
apurados 2 valores - o valor médio e o valor $90 \%$. Para a etapa de maturidade, os padrões de DEC, FEC, FMA, TMA e T90\%, por família, serăo expressos por
este par de valores, considerando o par mais restritivo dentre:

- o relativo à própria ELEKTRO;

- O relativo ao Estado de São Paulo, a ser determinado pelo órgão regulador, com base nos valores verificados em todas as empresas concessionárias de distribuição de energia elétrica do Estado.

c) TAI - Tempo de Atendimento Individual

O Tempo de Atendimento Individual năo poderá ultrapassar os seguintes limites:

- consumidores atendidos em tensảo inferior a 69 kV, localizados na área urbana: 10 horas;

- consumidores atendidos em tensão inferior a 69 kV, localizados na área rural: 12 horas;

- consumidores atendidos em tensăo igual ou superior a $69 \mathrm{kV}: 2$ horas.

d) DIC e FIC - Duração e Frequência de Interrupção Individual

Os padröes anuais de DIC e FIC serão apurados através de procedimento estatístico, considerando os índices verificados nos três anos da etapa de transiçăo, não superados por um valor a ser definido pelo órgăo regulador, situado entre $98,5 \%$ e $99,5 \%$ dos consumidores envolvidos, para a ELEKTRO como um todo e cada
uma de suas respectivas Áreas de Apuração.

Se os valores apurados forem superiores aos padrões vigentes durante a etapa de transição, serão mantidos estes últimos também para a etapa de maturidade.

Os padrões mensais corresponderão a 0,4 vezes os respectivos padrões anuais.

Os padrőes trimestrais serăo os menores dentre os seguintes valores:

- 3 vezes os respectivos padrões mensais;

- os limites impostos pela portaria $n^{\circ} 046$ do DNAEE, de 17/04/78.

e) FEV e FDT - Frequência Equivalente de Violação de Tensão e Função Distribuição de Tensão

Também para esta etapa, a fixação de padrōes relativos a adequação da tensão de fornecimento, vista de
modo coletivo, será decorrente de avaliaçōes a serem realizadas durante transição.

Nesta etapa deverá haver convergência para os niveis de tensão adequados. Deste modo, o padrão de FEV
será zero.

\subsection{V - INDICADORES DE QUALIDADE DO ATENDIMENTO COMERCIAL}

Em todas as etapas de implantaçăo do controle da qualidade do atendimento comercial utilizam-se os mesmos indicadores, indicados a seguir, os quais deverão ser apurados de forma mensal - referidos ao mês anterior, e anual meses, obedecidos os procedimentos fixados no Apêndice E:

- Tempo médio de ligação nova em baixa tensão;

- Tempo médio de religação em baixa tensão; 

- Tempo médio de elaboração de estudos e orçamentação de serviços na rede de distribuição para atendimento a
novas ligações ou a alteraçóes de carga;

- Tempo médio de execução de serviços na rede de distribuição, para atendimento a novas ligações ou alterações de carga, após apresentação do projeto e orçamento ao interessado e sua correspondente aprovação e pagamento,
quando for o caso;

- Porcentagem de perdas comerciais.

Com base nestes indicadores o órgão regulador poderá fazer comunicados ou auditorias, quando verificar tendência de perda de qualidade ou de ultrapassagem de limites.

\section{VI - PADRÕES DE QUALIDADE DO ATENDIMENTO COMERCIAL}

Os padrões regulamentares que deverăo ser obedecidos estão apresentados nas tabelas a seguir.

Citados padrões serão exigidos nas 2 etapas e seu cumprimento será aferido pelo órgão regulador através de auditorias por ela realizadas ou contratadas, em função das tendências observadas no histórico de indicadores coletados, de resultados desfavoráveis obtidos em pesquisas de opinião e de reclamaçőes formuladas por consumidores. Os prazos mencionados serăo contados a partir do momento da solicitação do consumidor, quando fixados em horas, e
a partir da data da solicitação, quando estabelecidos em dias úteis. 
tabela VII - padrões individuais de qualidade do atendimento comercial, para consumidores atendidos em tensão de distribuição

\begin{tabular}{|c|c|c|}
\hline 1.a) Prazo máximo nara o atendimente n nodidne da ling & $\begin{array}{l}\text { Etapa de } \\
\text { Adaptação }\end{array}$ & $\begin{array}{l}\text { Etapa de } \\
\text { Maturidade }\end{array}$ \\
\hline $\begin{array}{l}\text { 1.a) Prazo máximo para o atendimento a pedidos de ligação, quando se tratar de } \\
\text { fornecimento em média tensão, excluídos os casos de inexistência de rede de } \\
\text { distribuição em frente à unidade consumidora a ser ligada, de necessidade de } \\
\text { reforma ou ampliação da rede, de necessidade de construção de ramal } \\
\text { subterrâneo ou de inadequação das instalaçőes do consumidor aos padröes } \\
\text { técnicos da ELEKTRO. }\end{array}$ & 10 dias úteis & 5 dias úteis \\
\hline $\begin{array}{l}\text { 1.b) Prazo máximo para o atendimento a pedidos de ligação, quando se tratar de } \\
\text { fornecimento em baixa tensão, incluindo a vistoria que a aprovar e excluídos os } \\
\text { casos de inexistência de rede de distribuiçăo em frente à unidade consumidora } \\
\text { a ser ligada, de necessidade de reforma ou ampliação da rede, de necessidade } \\
\text { de construção de ramal subterrâneo ou de inadequação das instalaçōes do } \\
\text { consumidor aos padröes técnicos da ELEKTRO. }\end{array}$ & 4 dias úteis & 2 dias úteis \\
\hline $\begin{array}{l}\text { 2. Prazo máximo para o atendimento a pedidos de religação, após cessado o } \\
\text { motivo da suspensão do fornecimento e pagos os débitos, prejuizos, taxas, } \\
\text { multas e acréscimos incidentes. }\end{array}$ & 48 horas & 24 horas \\
\hline $\begin{array}{l}\text { 3. Prazo máximo para a comunicação dos resultados dos estudos, orçamentos, } \\
\text { projetos e do prazo para início e conclusão das obras de distribuição, } \\
\text { necessárias ao atendimento dos pedidos de ligaçăo năo cobertos nos itens 1.a } \\
\text { e 1.b. }\end{array}$ & 25 dias úteis & 15 dias úteis \\
\hline $\begin{array}{l}\text { 4. } \quad \begin{array}{c}\text { Prazo máximo para o início das obras referentes ao item anterior, após } \\
\text { satisfeitas, pelo interessado, as condiçőes gerais de fornecimento. }\end{array} \\
\text { 5. } \quad \text { Prazo máximo para devolucão }\end{array}$ & 30 dias úteis & 15 dias úteis \\
\hline $\begin{array}{l}\text { 5. Prazo máximo para a devolução, ao consumidor, de valores referentes a } \\
\text { indenizaçăo por danos em aparelhos elétricos provocados por problemas na } \\
\text { rede da ELEKTRO, comprovados por análise técnica. }\end{array}$ & 30 dias úteis & 20 dias úteis \\
\hline $\begin{array}{l}\text { 6. Prazo máximo para a devolução, ao consumidor, de valores referentes a erros } \\
\text { de faturamento que tenham resultado em cobranças a maior do cliente. }\end{array}$ & 10 dias úteis & 5 dias úteis \\
\hline $\begin{array}{l}\text { 7. Prazo máximo para a religação de unidades consumidoras que tenham sofrido } \\
\text { corte indevido no fornecimento de energia elétrica. }\end{array}$ & 4 horas & 4 horas \\
\hline $\begin{array}{l}\text { 8. Prazo máximo para a regularização da medição, na ocorrência de defeitos no(s) } \\
\text { medidor(es) instalado(s) na unidade consumidora. }\end{array}$ & 4 dias úteis & 2 dias úteis \\
\hline
\end{tabular}
tabela VIII- padrões individuais de qualidade do atendimento comercial, para consumidores atendidos em alta
tensão

\begin{tabular}{|c|c|c|}
\hline Descriçăo & $\begin{array}{c}\text { Etapa de } \\
\text { Adaptação }\end{array}$ & $\begin{array}{l}\text { Etapa de } \\
\text { Maturidade }\end{array}$ \\
\hline $\begin{array}{l}\text { 1. Prazo máximo para a apresentação, ao consumidor, de informações referentes à } \\
\text { possibilidade e às condições de atendimento a pedidos de novas ligações, } \\
\text { incluindo o tempo necessário para a conclusão de estudos, projetos e } \\
\text { orçamentos e os prazos para início e fim de eventuais obras, após satisfeitas, } \\
\text { pelo interessado, as condiçőes gerais de fornecimento } \\
\text { 2. Prazo máximo para a devolucão, ao consumidor }\end{array}$ & 30 dias úteis & 20 dias úteis \\
\hline $\begin{array}{l}\text { 2. Prazo máximo para a devolução, ao consumidor, de valores referentes a erros de } \\
\text { faturamento que tenham resultado em cobranças a maior do cliente. } \\
\text { 3. Prazo máximo para a regularizacão da medicão }\end{array}$ & 10 dias úteis & 5 dias úteis \\
\hline $\begin{array}{l}\text { 3. Prazo máximo para a regularização da medição, na ocorrência de defeitos no(s) } \\
\text { medidor(es) instalado(s) na unidade consumidora. }\end{array}$ & 4 dias úteis & 2 dias úteis \\
\hline
\end{tabular}

Para avaliação do cumprimento ou não dos padrões estabelecidos nas tabelas VII e VIII não serão considerados os atrasos que ocorrerem devido a providências que dependam do consumidor.

\section{VII - PENALIDADES E OUTRAS OBRIGAÇÕES}

\section{I.5 VII.1-Penalidades}

Os indicadores controlados nas etapas descritas anteriormente, quando transgredirem os padrões estabelecidos, gerarão penalidades à ELEKTRO, havendo dois grupos de degradação de qualidade: 
Grupo 1 - $\quad$ Fato Gerador:

Penalidade:

Grupo 2 - $\quad$ Fato Gerador:

Penalidade:

violação de padrão de qualidade que afeta um único consumidor, visto individualmente.

recolhimento, pela ELEKTRO, de multa específica conforme padrão năo atendido, a ser paga ao consumidor afetado no prazo máximo de 20 (vinte) dias úteis, a contar da data do registro da ocorrência, podendo ser creditada em conta de fornecimento de energia elétrica.

violação de padrão de qualidade que afeta um grupo de consumidores, ou transgressão de outras obrigaçöes descritas.

- quando se tratar de violação de padrão de qualidade de produto e de serviço, a ELEKTRO recolherá, ao órgão regulador, multa específica conforme padrão não atendido, no prazo máximo de 20 (vinte) dias, a contar da data de notificação formal;

- quando se tratar de violação de padrão de qualidade do atendimento comercial ou transgressåo de outras obrigações, o órgão regulador definirá o valor da penalidade conforme a transgressão, devendo ser recolhido pela ELEKTRO no prazo máximo de 20 (vinte) dias úteis após notificação formal.

As penalidades do Grupo 1, especificamente, deixarão de ser aplicadas no caso de acordo formal celebrado entre a ELEKTRO e o consumidor, em que se estabeleçam padröes de qualidade de serviço, produto ou atendimento
comercial melhores que os fixados neste documento.

Outras penalidades também poderão ser convencionadas entre os consumidores e a ELEKTRO, de acordo com contratos celebrados entre as partes.

Tais contratos, obrigatoriamente, deverão ser submetidos à homologação do órgão regulador.

A aplicação das penalidades do Grupo 2 para os indicadores DEC, FEC, FMA, TMA e T80\% ou T90\% considerarão uma tolerância de $10 \%$ na observância dos padröes definidos para a $1^{\mathrm{a}}$ etapa e $5 \%$ para a $2^{\mathrm{a}}$ etapa. Para DEC e FEC, esta tolerância será ignorada caso os indicadores ultrapassem os limites fixados pela portaria $n^{\circ}$
046 do DNAEE, de 17/04/78.

\subsection{VII.2 - Penalidades para o descumprimento de Padrões de Qualidade de Serviço e do Produto}

As penalidades para o descumprimento de padrōes de qualidade de serviço e do produto são calculadas com base no faturamento mensal do fornecimento de energia elétrica, realizado pela ELEKTRO para o(s) consumidor(es) Neste documento, este coeficiente utização de um coeficiente que variará entre 10 e 20 , a critério do órgão regulador.

\section{VII.2.1 - Penalidades do Grupo 1}

Para os indicadores de qualidade de serviço e do produto, serăo aplicadas penalidades do Grupo 1 para os casos de descumprimento dos padröes fixados para DIC, FIC, TAI e níveis de tensão. Somente para consumidores atendidos em média ou alta tensão, serão aplicadas penalidades para os casos de
violação dos padrōes estabelecidos para níveis de tensão.

Havendo solicitação do consumidor afetado ou do órgão regulador, a ELEKTRO deverá apurar o DIC e o FIC anuais, referidos ao último ano civil e aos últimos 12 meses, bem como o DIC e o FIC mensais e trimestrais,
para os mesmos períodos.

Para cada indicador anual, trimestral ou mensal, constatada a ultrapassagem de seu padrão correspondente, a ELEKTRO deverá adotar as providências cabíveis para solução do problema, obedecida a metodologia para
conduçăo do assunto contida neste documento.

A ELEKTRO deverá, ainda, calcular e pagar ao consumidor envolvido, valor equivalente à soma das penalidades correspondentes a cada transgressão - mensal, trimestral e anual, para os indicadores DIC e FIC. Nos casos em que a transgressão dos padrőes de DIC e FIC tiver o mesmo fato gerador, será aplicada apenas a multa correspondente ao maior valor dentre os apurados através das expressőes apresentadas a seguir. 
Para efeito do pagamento de penalidades por transgressōes de DIC e FIC trimestrais e anuais, serão considerados os trimestres civis e $\mathrm{O}$ ano civil, evitando-se duplicidade de pagamento.

A ELEKTRO deverá cumprir as seguintes obrigaçōes adicionais:

a) deixar disponível a legislação referente às condiçöes gerais de fornecimento de energia elétrica em todos pontos de atendimento ao público, para conhecimento e consulta pelos interessados;

b) realizar todas as ligações novas, obrigatoriamente, com a instalação de medição, excluindo-se casos específicos previstos na regulamentaçăo; c)fornecer ao consumidor, quando do pedido de serviços à ELEKTRO, protocolo com os prazos regulamentares
relativos aos serviços solicitados;

d) informar verbalmente ao consumidor, quando o pedido de serviços for realizado através de atendimento telefônico, os prazos regulamentares relativos aos serviços solicitados, além de identificação do atendente $e$ número do protocolo de atendimento;

e) manter registros de reclamaçőes dos consumidores, à disposição dos interessados; f) responder a toda consulta ou reclamaçăo formulada por seus clientes, obedecido o prazo máximo de 10 dias
úteis;

g) nos casos de reforma e/ou extensão de redes de distribuição de energia elétrica, não utilizar padrões construtivos diferentes dos adotados nas redes já implantadas em cada respectivo logradouro, salvo se para melhoria ou modernização das condiçőes de atendimento aos consumidores, sem prejuizo das características urbanisticas ou ambientais existentes;

h) submeter à aprovaçăo do órgão regulador, até o final do mês de setembro de cada ano, plano de inspeção e de aferição programada de equipamentos de medição instalados nas unidades de consumo existentes;

i) fornecer ao órgão regulador, até o final do mês de janeiro de cada ano, os resultados das inspeções e aferições programadas de que trata o item acima, referentes ao ano imediatamente anterior;

j) dar ciência aos consumidores envolvidos, com a antecedência devida, sobre as interrupçőes programadas no fornecimento de energia elétrica, através de meios eficazes de comunicaçăo. Além das obrigações acima indicadas e dos procedimentos contidos neste documento, apresentam-se a seguir
outras providências que deverăo ser rigorosamente cumpridas pela ELEKTRO:

a) Quanto aos indicadores coletivos DEC e FEC

Sempre que ocorrer ultrapassagem dos padrōes exigidos, a ELEKTRO terá que, no prazo máximo de 180 dias a contar da data do recebimento de notificaçăo, efetivamente solucionar o problema.

Até 30 dias da referida notificaçăo, a ELEKTRO deverá informar ao órgão regulador a data de conclusão das providências a serem adotadas, descrevendo as causas e a programaçã̃o das açöes previstas.

b) Quanto aos indicadores individuais DIC e FIC Sempre que houver reclamaçőes de consumidores individuais ou por solicitação do órgão regulador, a
ELEKTRO deverá proceder da seguinte forma: - num prazo máximo de 30 dias da data do recebimento da reclamação, enviar carta resposta ao reclamante,
contendo o resultado da apuração;

- caso a apuração demonstre violação do padrão estabelecido, a ELEKTRO deverá, dentro de prazo acordado com o consumidor e que năo poderá superar 180 dias contados a partir da emissão da carta citada no item anterior, efetivamente solucionar o problema;

- a apuração de DIC e FIC não acarretará qualquer ônus ao consumidor envolvido ou ao órgão regulador, sendo todos os custos decorrentes desta atividade assumidos pela ELEKTRO.

c)Quanto aos niveis de tensão

O prazo para resposta a uma solicitação de medição da tensão de fornecimento, através de correspondência escrita com fornecimento dos resultados da medição, é de 30 (trinta) dias, a contar do recebimento da
solicitaçăo. 
O prazo para a tomada de providências, realizaçăo de novas mediçőes e envio de correspondência ao solicitante comunicando a correção da irregularidade, quando se constatar inadequação da tensão, é de:

- (noventa) dias após recebimento da solicitação, quando for constatado que as tensões medidas estão fora dos limites precários; - (cento e oitenta) dias, quando for constatado que as tensões medidas estão fora dos limites adequados mas
dentro dos limites precários.

Até 30 dias da constatação da ocorrência, a ELEKTRO deverá informar ao órgão regulador a data de conclusão das providências a serem adotadas, descrevendo as causas e a programação das ações previstas. Os resultados das medições, inclusive relatórios gerados por equipamento de medição em forma de gráfico ou
de planilha, devem ser arquivados pela ELEKTRO pelo prazo de 3 (três) anos.

Após a tomada de providências para trazer os níveis de tensão para dentro dos limites adequados, uma nova 48 horas de antecedência.

São ainda obrigações da ELEKTRO:

a) a realização de pesquisas periódicas de satisfação de consumidores

As pesquisas deverão abordar a satisfação dos consumidores com respeito, dentre outros, aos seguintes
aspectos

- Frequência e duração das interrupções no fornecimento de energia elétrica;Qualidade do produto - nível de tensăo, variações de tensão, interferências e qualidade da forma de onda; - Atendimento pessoal e ou telefônico comercial e de emergência, em termos de disponibilidade do serviço,
atenção, presteza e eficiência; - Serviços prestados pela ELEKTRO, tais como ligação, religação, leitura de medidores, entrega de contas,
orçamentos para extensões de rede;

- Orientações obrigatórias feitas pela ELEKTRO sobre o uso seguro e adequado da energia elétrica;

- Esclarecimentos obrigatórios sobre direitos e deveres dos consumidores;

- Serviço de iluminação pública;

- Imagem institucional da ELEKTRO;

- Tarifas de fornecimento e taxas de serviços;

- Notificaçőes sobre interrupçőes programadas.

Para consumidores atendidos em alta tensão, tendo em vista o universo restrito destes consumidores, a ELEKTRO deverá avaliar anualmente, dentre outras, as seguintes informaçő́es, através de questionário

- Frequência e duração das interrupções;

- Qualidade do produto - nível de tensão, variações de tensão, interferências e qualidade de forma de onda;

- Atendimento comercial e de emergência;

- Esclarecimentos obrigatórios da ELEKTRO;

- Tarifas de fornecimento.

Compiladas as respostas, a ELEKTRO deverá encaminhar relatório especifico ao órgão regulador.

b) elaboração e encaminhamento de relatórios de acidentes, de programas especiais, de mercado e faturamento e relatórios específicos 
Esses relatórios serão obrigatórios e deverão ser enviados periodicamente ou quando solicitados pelo órgão regulador. Visam permitir que o órgão regulador analise o desempenho da ELEKTRO no que se refere a:

- Acidentes

- Empregados acidentados no ano, inclusive os de empresas contratadas, com indicação, no mínimo, de causas e níveis de gravidade dos acidentes ocorridos;

- Acidentes com terceiros envolvendo a rede de energia elétrica, com indicação de respectivas causas e níveis de gravidade, bem como de ações corretivas nos casos de inadequação de instalaçöes da
ELEKTRO;

- Campanhas preventivas sobre acidentes no uso de energia elétrica;

- Pedidos de Indenização por queima de aparelhos e indenizaçōes efetivamente pagas pela ELEKTRO.

Este relatório será encaminhado anualmente ao órgão regulador.

- Programas Especiais

- Conservação de energia elétrica;

- Programas/Atendimentos sociais, como a desempregados, consumidores de baixa renda, aposentados, entidades sem fins lucrativos, eletrificação rural, dentre outros;

- Pesquisa e desenvolvimento em sistemas comerciais e em tecnologia.

Este relatório será encaminhado anualmente ao órgão regulador.

- Mercado e Faturamento

- Número de consumidores atendidos, energia vendida e valores faturados, a cada mês, por categoria de consumo, para a ELEKTRO como um todo, Areas de Apuração e conjuntos de consumidores.

Este relatório será encaminhado trimestralmente ao órgão regulador.

- Relatórios Específicos

A critério do órgão regulador poderão ser solicitados relatórios sobre temas específicos. 0 ônus da elaboração desses relatórios extraordinários fica a cargo da ELEKTRO.

No que diz respeito aos consumidores atendidos em alta tensão, ao suprimento de energia e ao planejamento de obras na sua rede de alta tensão, a ELEKTRO deverá enviar ao órgão regulador, anualmente, os seguintes relatórios:

- Relação de clientes em alta tensăo destacando:

- vigência dos contratos;

- tipo de contrato - com ou sem fornecimento energético;

- grandezas contratadas - potência e energia;

- níveis de qualidade do produto, serviço e atendimento contratados, caso sejam diferentes dos
padrões mínimos;

- tarifas contratuais - Relação dos contratos de suprimento e de transporte firmados com outras concessionárias ou
produtores independentes:

- vigência dos contratos;

- grandezas contratadas - demandas, energias;

- tarifas contratuais.

- Planejamento de obras:

- relaçăo das obras e dos investimentos previstos para os próximos 5 anos nas redes de alta tensăo.

\subsection{1.1 VII.5 - Penalidades para o Descumprimento de Prazos e Outras Obrigações da ELEKTRO}

Haverá aplicação de multa à ELEKTRO em valor a ser definido pelo órgão regulador, cada vez que for constatado o estipulados nesto de qualquer uma das suas obrigaçōes citadas no item anterior, bem como qualquer um dos prazos serviço ou atendimento comercial detectadas. 


\section{ANEXO III - Minuta de Projeto de Lei do Deputado Rui Falcão}

- O CONSESPE constituiria uma unidade de despesa e gozaria de autonomia técnica e administrativa;

- O CONSESPE seria um órgão consultivo, deliberativo e controlador das ações de política de energia no âmbito do estado, com os seguintes objetivos:

1 - fixaria a política estadual referente à exploraçăo e aproveitamento das fontes de energia;

2 - regularia, controlaria e fiscalizaria os serviços de geração, transmissão e distribuição de energia elétrica; e

3 - que por delegação da União, o CONSESPE ficaria autorizado a celebrar convênios com órgãos ou entidades do Poder Concedente, bem como com os Estados ou Municípios, para atuação em caráter de cooperação e para articulação de políticas interestaduais.

A realização dos objetivos do CONSESPE estariam condicionados pelas seguintes diretrizes:

1 - Garantir a universalização do acesso à energia elétrica;

2 - Proteger o consumidor em termos de preços, continuidade e qualidade do fornecimento e garantia do serviço adequado;

3 - Proteger o equilibrio econômico-financeiro das concessionárias, mediante preços, custos e tarifas equilibradas, e adequada metodologia tarifária, respeitadas a modicidade e a capacidade de pagamento dos usuários como forma de garantir o serviço adequado;

4 - Assegurar a transparência de gestão das concessionárias para a sociedade;

5 - Garantir a operação do sistema com confiabilidade e segurança e coibir a ocorrência de discriminação no seu uso e acesso;

6 - Assegurar o direito das pessoas de acesso a informações do setor, e a divulgação de dados quanto ao potencial e situação dos serviços e modos de utilização, bem como aos critérios para a determinação dos valores cobrados pelo consumo.

Para a consecução de seus objetivos o CONSESPE, valer-se-ia dos seguintes instrumentos:

1 - poder de diligência e acesso irrestrito às informações do setor;

2 - Convênios e contratos com órgãos, ou entidades públicas e privadas;

3 - Planilhas de custos, preços e tarifas;

4 - Audiências públicas, regulamentadas em seu regimento

5 - Normas e padrões de qualidade para a produção, transmissão e fornecimento

6 - Campanhas de informaçăo e divulgação sobre programas sociais no setor. 


\section{ANEXO IV - Código de Defesa do Consumidor}

\section{Definição de consumidor, fornecedor, produto e serviço}

"Art. $2^{\circ}$. - Consumidor é toda pessoa física ou jurídica que adquire ou utiliza produto ou serviço como destinatário final.

Parágrafo Único - Equipara-se a consumidor a coletividade de pessoas, ainda que indetermináveis, que haja intervindo nas relaçőes de consumo".

"Art. $3^{\circ}$. - Fornecedor é toda pessoa física ou jurídica, pública ou privada, nacional ou estrangeira, bem como os entes despersonalizados, que desenvolvem atividades de produção, montagem, criação, construção, transformaçăo, importação, exportação, distribuiçăo ou comercialização de produtos ou prestação de serviços.

Parágrafo Primeiro - Produto é qualquer bem, móvel ou imóvel, material ou imaterial.

Parágrafo Segundo - Serviço é qualquer atividade fornecida no mercado de consumo, mediante remuneração, inclusive as de natureza bancária, financeira, de crédito e securitária, salvo as decorrentes de caráter trabalhista".

\section{Instrumentos de defesa do consumidor}

"Art. $4^{\circ}$. - A Política Nacional de Relaçöes de Consumo tem por objetivo 0 atendimento das necessidades dos consumidores, o respeito à sua dignidade, saúde e segurança, a proteção de seus interesses econômicos, a melhoria da sua qualidade de vida, bem como a transparência e harmonia das relações de consumo, atendidos os seguintes princípios:

I- reconhecimento da vulnerabilidade do consumidor no mercado de consumo;

II - ação governamental no sentido de proteger efetivamente o consumidor:

a) por iniciativa direta;

b) por incentivo à criaçăo e desenvolvimento de associaçőes representativas;

c) pela presença do Estado no mercado de consumo;

d) pela garantia dos produtos e serviços com padrões adequados de qualidade, segurança, durabilidade e desempenho;

III - harmonização dos interesses dos participantes das relações de consumo e compatibilização da proteção do consumidor com a necessidade de desenvolvimento econômico e tecnológico, de modo a viabilizar os princípios nos quais se funda a ordem econômica (art.170, da Constituição Federal), sempre com base na boa-fé e equilíbrio nas relaçöes entre consumidores e fornecedores:

IV - educação e informação de fornecedores e consumidores, quanto aos seus direitos e deveres, com vistas à melhoria do mercado de consumo;

V - incentivo à criação, pelos fornecedores, de meios eficientes de controle de qualidade e segurança de produtos e serviços, assim como de mecanismos alternativos de solução de conflitos de consumo;

VI - coibição e repressão eficientes de todos os abusos praticados no mercado de consumo

VII - racionalização e melhoria dos serviços públicos; 


\section{Responsabilidade por danos}

“Art. 14 - 0 fornecedor de serviços responde, independentemente da existência de culpa, pela reparaçăo dos danos causados aos consumidores por defeitos relativos à prestação dos serviços, bem como por informaçőes insuficientes ou inadequadas sobre sua fruição e riscos".

Parágrafo Primeiro - O serviço é defeituoso quando não fornece a segurança que o consumidor dele pode esperar levando-se em consideração as circunstâncias relevantes, entre as quais:

I- o modo de seu fornecimento;

II - os resultados e os riscos que razoavelmente dele se esperam;

Parágrafo Segundo - O serviço não é considerado defeituoso pela adoção, de novas técnicas.

Parágrafo Terceiro - $O$ fornecedor de serviços só não será responsabilizado quando provar:

I- que, tendo prestado o serviço, o defeito inexiste;

II - a culpa exclusiva de consumidor ou de terceiro;"

“Art. 22 - Os órgãos públicos, por si ou suas empresas, concessionárias, permissionárias ou sobre qualquer outra forma de empreendimento são obrigadas a fornecer serviços adequados, eficientes, seguros e, quanto aos essenciais, contínuos.

Parágrafo Único - Nos casos de descumprimento, total ou parcial, das obrigações referidas neste artigo, serão as pessoas jurídicas compelidas a cumpri-las e a reparar os danos causados, na forma prevista no Código."

\section{Orçamentos e execução de serviços}

Art. 39 - É vedado ao fornecedor de produtos e serviços:

VI - executar serviços sem a prévia elaboração de orçamento e autorização do consumidor, ressalvadas as decorrentes de práticas anteriores entre as partes;

IX - deixar de estipular prazo para o cumprimento de sua obrigaçăo ou deixar a fixação de seu termo inicial a seu exclusivo critério;"

"Art. 40 - O fornecedor de serviço será obrigado a entregar ao consumidor orçamento prévio discriminando o valor da mão-de-obra, dos materiais e equipamentos a serem empregados, as condições de pagamento, bem como as datas de início e término dos serviços.

Parágrafo Primeiro - Salvo estipulação em contrário, o valor orçado terá validade pelo prazo de dez dias, contado de seu recebimento pelo consumidor.

Parágrafo Segundo - Uma vez aprovado pelo consumidor, o orçamento obriga os contratantes e somente pode ser alterado mediante livre negociaçăo das partes.

Parágrafo Terceiro - O consumidor năo responde por quaisquer ônus ou acréscimos decorrentes da contratação de

\section{Cobrança de dívidas} serviços de terceiros, não previstos no orçamento prévio."

“Art. 42 - Na cobrança de débitos, o consumidor inadimplente não será exposto a ridículo, nem será submetido a qualquer tipo de constrangimento ou ameaça.

Parágrafo Único - $O$ consumidor cobrado em quantia indevida tem direito à repetição do indébito, por valor igual ao dobro do que pagou em excesso, acrescido de correçăo monetária e juros legais salvo hipótese e engano justificável."

Art. 61 - Constituem crimes contra as relaçōes de consumo previstas neste Código, sem prejuizo do disposto no Código Penal e leis especiais, as condutas tipificadas nos artigos seguintes.

“Art. 71 - Utilizar na cobrança de dividas, de ameaça, coação, constrangimento físico ou moral, afirmações falsas, incorretas ou enganosas ou de qualquer outro procedimento que exponha o consumidor, injustificadamente, a ridículo ou interfira com seu trabalho, descanso ou laser.

Pena - Detenção de três meses a um ano e multa." 


\section{ANEXO V - REGIMENTO INTERNO CONSELHO DE CLIENTES DA ELEKTRO}

\section{Denominação}

Conselho de Clientes de Energia Elétrica da ELEKTRO.

\section{Regulamentação} Lei no. 8631 , de 04/03/93, art.13, que institui o Conselho de Consumidores no âmbito das concessionárias de energia
elétrica.

\section{Objetivos}

- Representar os interesses das diversas classes consumidoras de energia elétrica junto a ELEKTRO, analisando e avaliando todas as questōes ligadas ao fornecimento, custos, preços, tarifas e qualidade dos serviços prestados, de acordo com a legislação vigente. - Estabelecer um canal de comunicaçăo permanente com a sociedade civil no sentido de diagnosticar continuamente
suas necessidades.

- Colher sugestões e viabilizar condiçōes que possibilitem melhorar a qualidade dos serviços de fornecimento, promover o uso eficiente de energia elétrica e contribuir no aperfeiçoamento das relaçöes junto aos clientes finais.

\section{Sede} O Conselho de Clientes será instalado na cidade de São Paulo, podendo a cada novo mandato, ser instalado em uma das
Sedes Regionais, em sistema de rodízio.

\section{Composição e Organização}

0 Conselho de Clientes terá caráter estritamente consultivo, sem fins lucrativos.

0 Conselho será composto por 8 (oito) membros titulares e 8 (oito) suplentes.

A representação no Conselho será da seguinte forma:

- 01 (um) representante da classe residencial;

- 01 (um) representante da classe comercial, serviços e outras atividades;

- 01 (um) representante da classe industrial;

- 01 (um) representante da classe rural;

- 01 (um) representante da classe de poder público, iluminação e serviços públicos;
- 01 (um) representante do PROCON;

- 01 (um) representante da ELEKTRO (sem direito a voto).

\section{Da Indicação dos Representantes}

Os membros titulares e suplentes do Conselho de Clientes deverão ter suas atividades e residências localizadas nas áreas servidas pela ELEKTRO, e serão indicados por entidades que representem cada uma das classes nela representadas, a
saber: - Residencial, indicado pelo Conselho Coordenador das Sociedades Amigos de Bairros, Vilas e Cidades do Estado de
São Paulo - CONSABESP;

- Comercial, serviços e outras atividades, indicado pela Federação do Comércio do Estado de São Paulo - FCESP;

- Industrial, indicado pela Federaçăo das Indústrias do Estado de São Paulo - FIESP;

- Rural, indicado pela Federaçăo da Agricultura do Estado de São Paulo - FAESP;

- Poder Público, lluminação e Serviços Públicos, indicado pela Associação Paulista de Municípios - APM;

- Coordenadoria de Proteção e Defesa do Consumidor - PROCON, indicado pelo mesmo;

- ELEKTRO, indicado pela Diretoria da Empresa.

\section{Da Eleição e Remuneração}

O Conselho de Clientes terá um Coordenador, eleito entre seus membros no início de cada mandato, sendo vedado, ao representante da ELEKTRO, o exercicio deste cargo. 
0 Conselho de Clientes terá um Secretário Executivo, eleito entre seus membros no início de cada mandato. 0 exercício da função de membro do Conselho năo será remunerado, sendo vedada a participação nele de ocupantes de
cargo público eletivo.

\section{Dos Mandatos}

0 mandato de todos os membros titulares do conselho será de 2 (dois) anos, não podendo ser renovado.

0 mandato do Coordenador do Conselho será de 1 (um) ano, não podendo ser renovado.

\section{Da Destituição}

Qualquer membro do Conselho poderá ser destituído a qualquer tempo pela entidade que o indicou ou por decisão do Conselho pela ausência injustificada a 3 (três) reuniőes seguidas ou 4 (quatro) alternadas, sendo neste caso substituido automaticamente pelo respectivo suplente.

Em caso de impossibilidade de participar da reunião, o membro titular deve comunicar e solicitar a presença do membro suplente, e informar essa ocorrência ao Secretário Executivo do Conselho.

Quando houver absoluta impossibilidade, prévia e plenamente justificada, dos membros titular e suplente comparecerem a alguma reunião, poderá ser indicado, com antecedência, um outro representante apenas para aquela reunião.

Sempre que um membro suplente passar a condição de titular, deverá ser indicado outro suplente para a vaga aberta.

\section{Da Duração}

0 Conselho de Clientes terá duração indeterminada.

\section{Das Atribuiçőes}

\section{Conselheiros:}

- Participar das reuniões atendendo a convocaçăo do Coordenador;

- Trazer sugestőes das entidades que representa e expor os assuntos que julgar pertinente;

- Levar às suas bases representativas as decisões do Conselho;

- Votar as decisōes do Conselho.

Coordenador:
Dirigir e coordenar os trabalhos e as reuniōes do Conselho;
- Representar o Conselho sempre que necessário;
Designar entre os Conselheiros seu eventual substituto;
- Expedir convocação para reunião do Conselho com antecipação de 10 (dez) dias:
- Assinar correspondência em nome do Conselho;
- Dar conhecimento prévio a ELEKTRO sobre o calendário anual de reuniozes ordinárias:
- $\quad$ - Todas as atribuiçő́es do Conselheiros.

Secretário Executivo:

Responder pelos encargos de Secretário do Conselho, tais como:

- Encaminhar aos Conselheiros a convocação para as reuniöes expedida pelo Coordenador, as cópias de documentos

- Secretariar as reuniöes e redigir suas atas:

- Encaminhar a ELEKTRO e aos Conselheiros cópia das atas de reuniões:

- Manter arquivo organizado das atas de reuniőes;

- Preparar respostas de correspondências:

- Enviar o calendário anual de reuniōes à ANEEL;

- Receber os clientes que desejarem apresentar problemas ao Conselho;

- Atuar junto a ELEKTRO, visando agilizar as soluçōes dos problemas submetidos ao Conselho;

- Assessorar o Coordenador nas reuniőes do Conselho;

- $\quad$ Givulgar aos membros do Conselho as decisőes da ELEKTRO advindas da atuação do próprio Conselho, e vice-versa;

\section{Das Reuniões}

Os assuntos a serem tratados na reunião deverão ser comunicados com antecedência mínima de 10 (dez) dias ao 
Coordenador, que os incluirá na pauta de discussőes.

No início do exercício será definido pelos membros um calendário de reuniöes ordinárias com periodicidade bimestral.

A realização das reuniōes, preferencialmente, será na cidade sede do Conselho, e está condicionada ao comparecimento da maioria simples dos Conselheiros, numa $1^{1}$. convocaçăo. Não havendo quorum suficiente, a reunião poderá ser realizada, numa $2^{\circ}$. convocação e 30 minutos após ao horário previsto, com qualquer número de Conselheiros presentes.

Outros Municípios atendidos pela ELEKTRO poderão eventualmente sediar reuniőes através de unidades descentralizadas das entidades representadas, a critério e como forma de divulgação do Conselho.

Reuniőes extraordinárias poderăo ser convocadas pelo Coordenador, por solicitação de algum Conselheiro ou pela ELEKTRO por solicitaçăo de seu Presidente.

\section{Da Atuação}

0 Coordenador abrirá a reunião lendo a pauta convocatória e em seguida, será aberta a palavra a todos os Conselheiros;

o Coordenador poderá convidar representantes de outras entidades, associaçőes e da própria ELEKTRO ou clientes individuais, para participar das reuniốes;

Após cada reunião, deverá ser feita a ata e distribuída aos participantes, a qual deverá ser lida na reunião seguinte e divulgada para os clientes.

0 representante da ELEKTRO deverá encaminhar as providências a respeito dos problemas levantados;

0 registro de frequeência dos Conselheiros nas reuniőes deverá se processar através de Lista de Presença, a qual deverá estar de posse do Coordenador do Conselho.

\section{Da Divulgação do Conselho}

A cada início de mandato, a composiçăo e o funcionamento do Conselho de Clientes será divulgada pela ELEKTRO no Diário Oficial do Estado e em outros jornais de circulação em toda área de concessão.

A divulgação das atividades do Conselho de Clientes, ficará por conta da ELEKTRO, de acordo com sua disponibilidade de recursos.

\section{Das Disposições Gerais}

As consultas a serem encaminhadas a ELEKTRO deverăo ser decididas por consenso, pelos membros do Conselho presentes na reuniäo.

Em caso de divergência quanto as consultas, as decisões sobre seu encaminhamento à ELEKTRO deverão ser tomadas através de votaçăo por maioria simples dos Conselheiros presentes.

Em caso de empate nas votaçöes, o voto de desempate deverá ser proferido pelo Coordenador.

0 presente regulamento foi elaborado com base na Lei $n \div$ - 8631 , de 04/03/93.

\section{Da Alteração do Regimento}

0 Conselho, respeitando a legislação, poderá alterar o presente Regimento, a qualquer tempo, desde que por consenso entre todos os seus membros. 